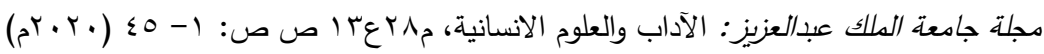
DOI:10.4197/Art.28-13.1

\section{التسليم للنصوص الثرعية وأثره في استقامة العقيدة}

\author{
أسماء بنت داود بن أحمد العلواني \\ أستاذ العقيذة والمذاهب المعاصرة المشارك \\ كلية القرآن الكريم والدراسات الإسلامية - قسم الدراسات الإسالامية \\ جامعة جدة - جدة المدلكة العربية السعودية
}

مستخلص .الحمد الله والصلاة والسلام على رسول الله، أما بعد: فإنَّ المحجة الواضحة والطريق الحق لعلم العقيدة

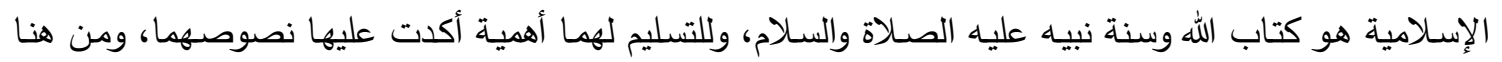
تبدو أهمية موضوع البحث، كما أن من أسباب اختياره: عظم أهمية استقامة العقيدة للنجاة في الدنيا والآخرة، وأن

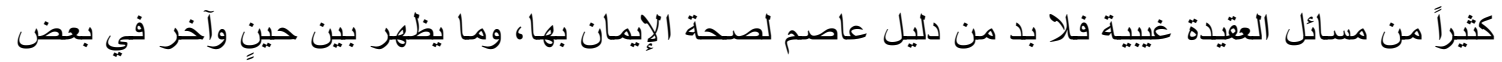
المجتمعات الإسلامية من دعواتٍ صريحها أو غايتها التمرد على النصوص الثرعية، وقد تتاول البحث حكم التسليم للنصوص الثرعية والانقياد لها، وتلقيها بالرضى، وترك الإباء والاعتراض عليها، وأدلته، ثم بين آثارَ التسليم

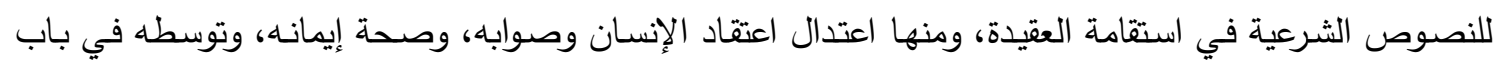

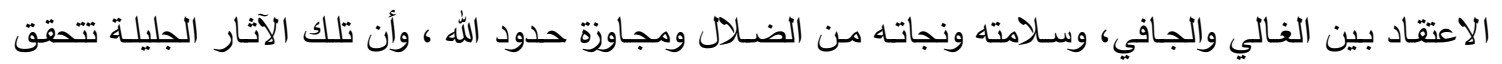
بمقدار ما يتحقق من التسليم.

$$
\text { الكلمات المفتاحية: التسليم - النصوص- الثرعية - العقيدة - استقامة - التلقي }
$$

نبينا محمداً عبده ورسوله صلى الله عليه وعلى آله

وأصحابه ومن اهتدى بهديه إلى يوم الدين. أما بعد:

فإنَّ المحجـة الواضـحة والطريـق الحـق لعلـم العقيدة الإسـلامية هـو كتاب الله وسـنة نبيـه عليـه الصـلاة

\section{المقدمة}

إن الحمــ الله نحمـده ونسـتعينه ونسـتهديه ونسـتغفره، ونعوذ بالله من شرور أنفسنا ومن سيئات أعمالنا، من يهـده الله فـلا مضـل لـه، ومن يضـلل فـلا هـادي لـه، وأشهد أن لا إله إلا الله وحده لا شريك لـه، وأشهح أن 
والسـلام، فـ"لا دليـل إلـى الله والجنـة، سـوى الكتـاب ثالثاً: بيان المراد بـ (الأثر). والسنة"(1)، ولهذا كان للتسليم لهما أهمية أكدت عليها رابعاً: بيان المراد بـ (الاستقامة). نصوصهما ودعت إليه في أكثر من موضع، وبينت خامساً: بيان المراد بـ (العقيدة). سادساً: بيان المراد بـ (التسليم للنصوص الثراد بـ الثرعية وأثره في استقامة العقيدة).

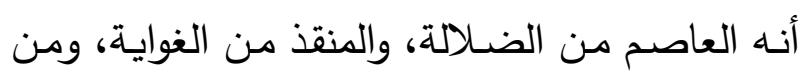
هنا تبدو أهمية موضوع البحث، ويبرز داعي الكتابة الهن

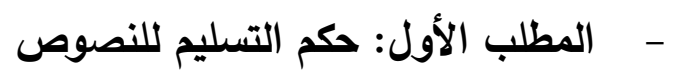
الثرعية وأدلته.

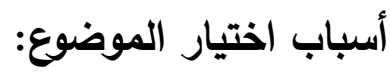
- المطلب الثاني: أثر التسليم للنصوص الثرعية في استقامة العقيدة. - - فهرس مراجع ومصادر البحث.

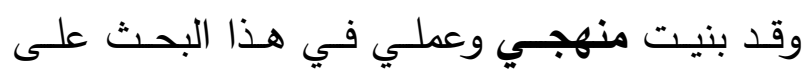

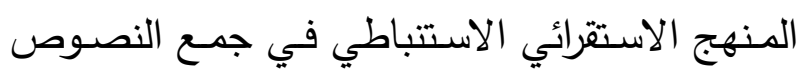
لاستخلاص حكم التسليم منها، ثم في بيان أثر ذلك الك

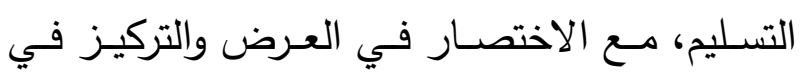

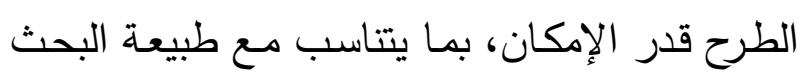

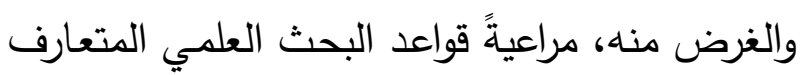

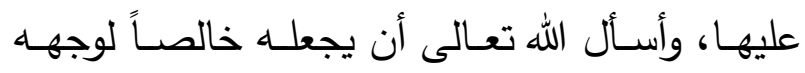

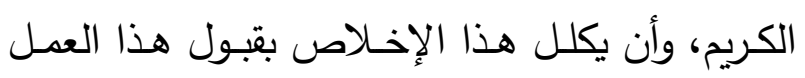

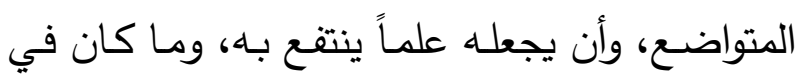

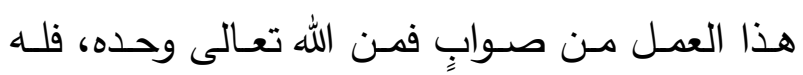

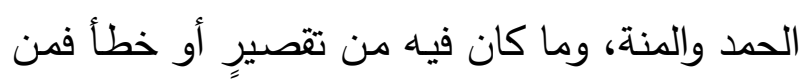

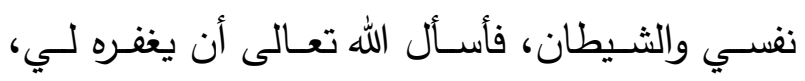

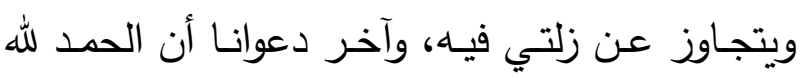

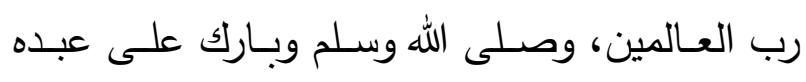
1- عظم أهميـة استقامة العقيدة للنجـاة في الدنيا والآخرة. r- أن كثيراً من مسائل العقيدة غيبية فلابد من دليل عاصم لصحة الإيمان بها. ץ- أن الهداية والسبيل إليها مطلب كل مؤمن للفوز

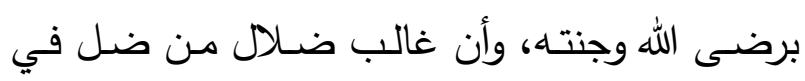

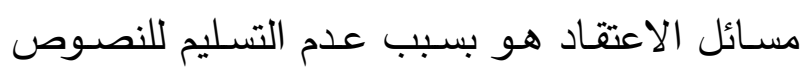
الشرعية. ـ - ما يظهر بين حينٍ وآخر في بعض المجتمعات

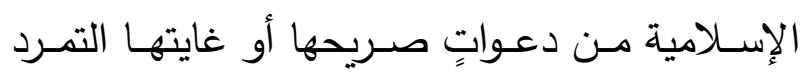
على النصوص الشرعية. هذا وقد جاءت خطة البحث على النحو التالي: - - المقدمة وفيها أهمية الموضوع وأسباب اختياره وخطة البحث والمنهج المتبع فيه. - مهريذ وفيه: بيان مصطلحات عنوان الموضوع

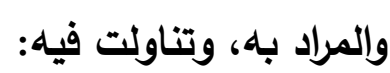
أولاً: بيان المراد بـ (التسليم). ثانياً: بيان المراد بـ (النصوص الشراد بـ (التيم). (1) مدارج السالكين لابن القيم T9/ץ؛ 
والمراد في هذا البحث هو النوع الأول. ثانياً: بيان المراد بـ (النصوص الثراد هو لثرعية):

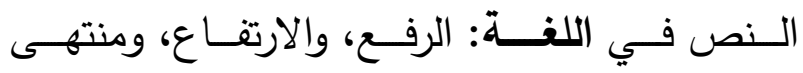
الثـيء (')"، و"منهـ قولهم: نصَّ الحديث إلى فـلانٍ:

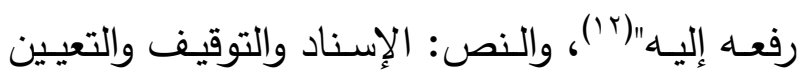
على شيء ما"(rا'). والثرعية: نسبة إلى الثرع، والثرع في اللغـة هو: الشريعة، وهي منهاج الطريق الواضح البين(؛ (').

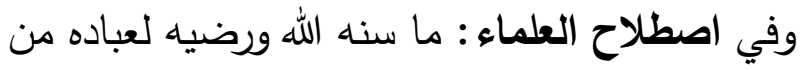

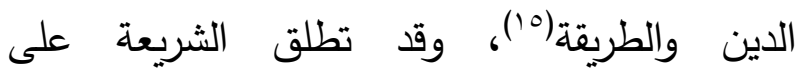
"التكاليف العملية التي جاء بها الإسلام في العبادات

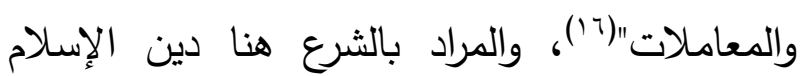
كله. والمـراد بالنصـوص الثــرعية آيـات القـرآن الكـريخ

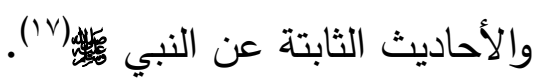

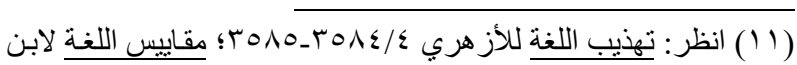

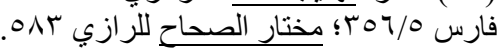

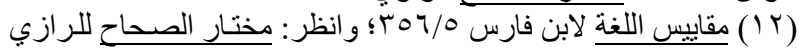

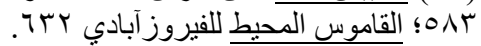

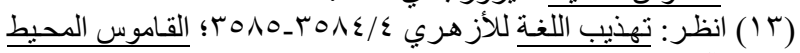

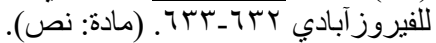

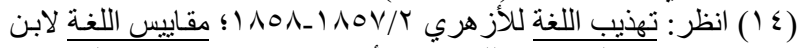

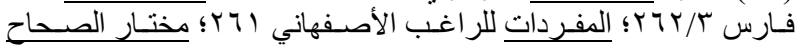

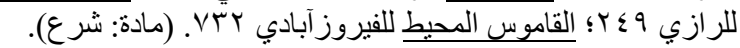

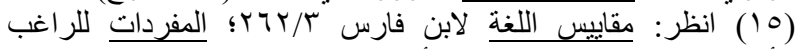

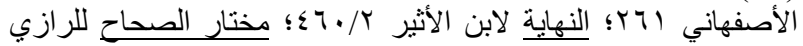

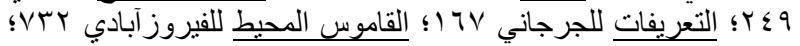

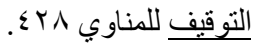

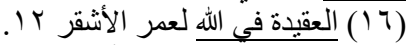

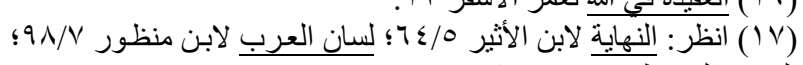

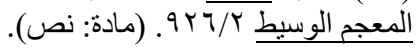

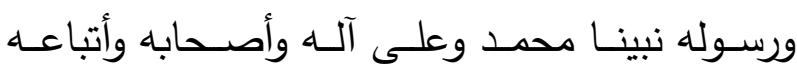
بإحسان. التمهيد: بيان مصطلحات عنوان الموضوع والمراد بله: أولاً: بيان المراد بـ (التسليم):

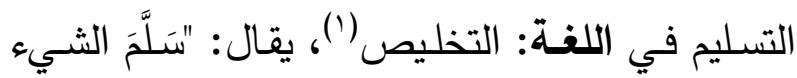

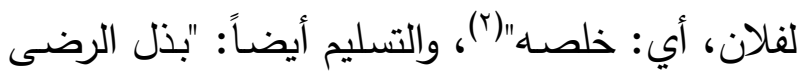

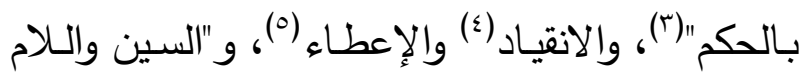
والميم معظم بابه من الصحة والعافية... ومن الباب أيضـاً الإســلام، وهو الانقيـاد؛ لأنـه يسلم مـن الإبـاء

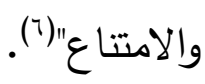
وعُرِّف التسـليم فـي الاصـــلاح الثــرعي بأنــه:

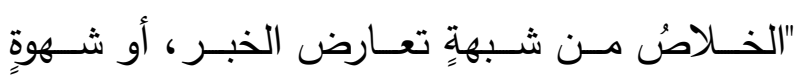

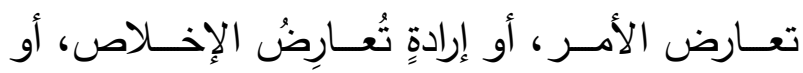

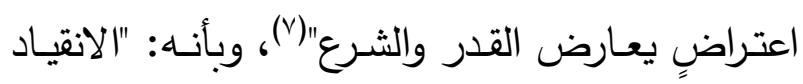

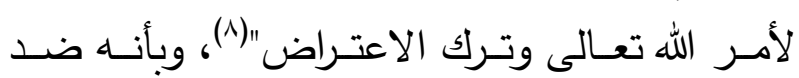

$$
\text { المنازعة (9). }
$$

والتسـليم الشـرعي نوعـان: تسـليم لحكم الله الــيني

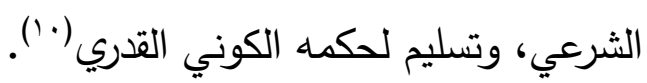

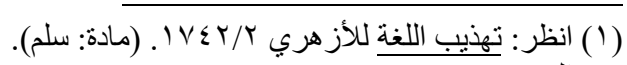

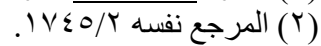

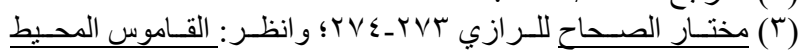

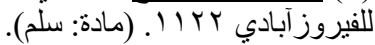

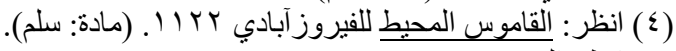

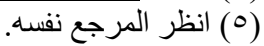

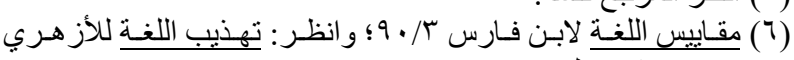

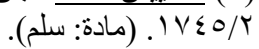

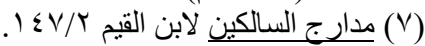

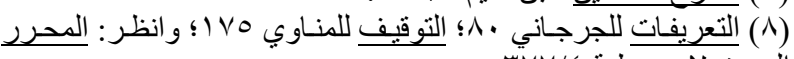

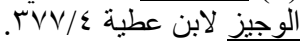

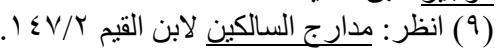

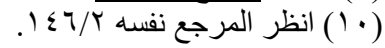




$$
\text { وعلى أمر الله("'). }
$$

خامساً: بيان المراد بـ (العقيدة):

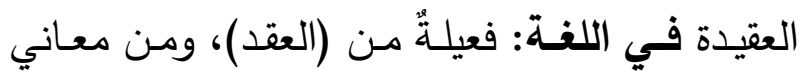

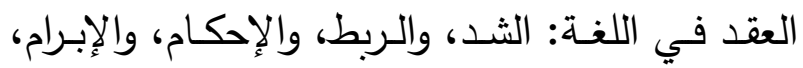

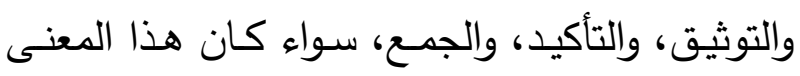

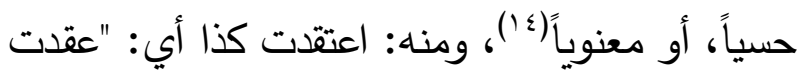

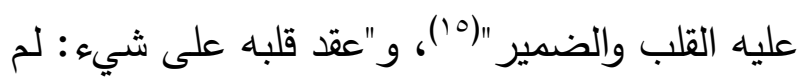
ينـزع عنـه"(17)، وعليـه فـ"العقيدة: مـا يدين الإنسـان به"(') ، ويعقد عليه قلبه عقداً شديداً موثقاً محكماً. وأما العقيدة في اصطلاح العلماء فلها معنيان: أ-المعنى العام: حكم الذهن اليقيني القاطع الذي لا لاعلاء يتطرق إليه الثك، حقاً كان أم باطلاًُ (1). ب -المعنى الخاص: وعرفت فيه العقيدة بحسب ما تضاف إليه(19). والمقصـود بالعقيدة في موضـوع هـذا البحثب هـو العقيدة المضـافة للإسـلام، أي: العقيدة الإسـلامية،

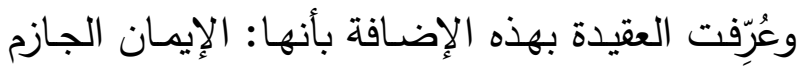

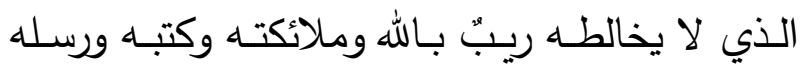

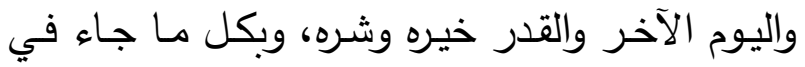

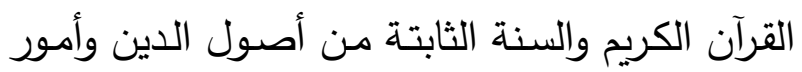

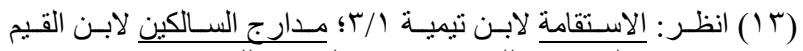

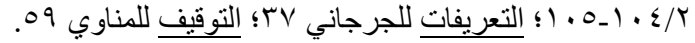

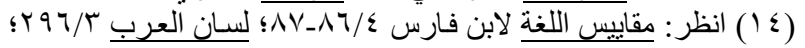

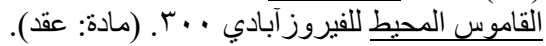

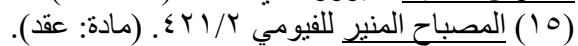

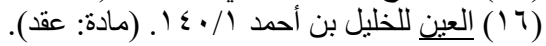

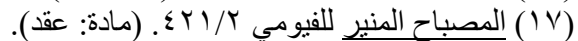

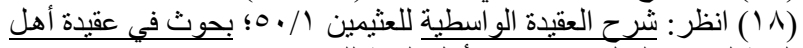

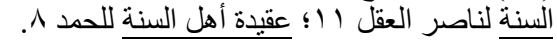

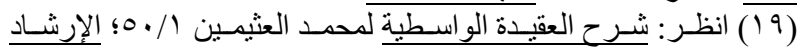
لصالح الفوزان · 1؛ عقيدة أهل السنة لمحمد الحمد ^.
ثالثاً: بيان المراد بـ (الأثر):

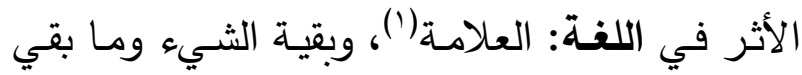

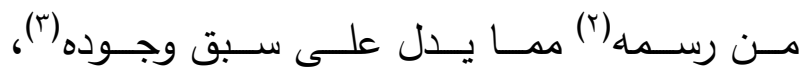

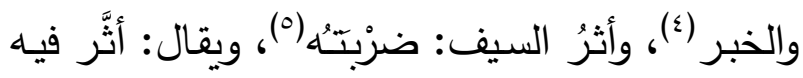

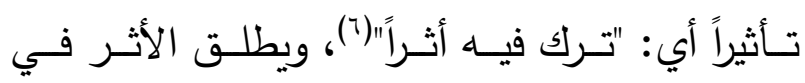
الاصطلاح على معانٍ منها الخبر المنقول عن النبي

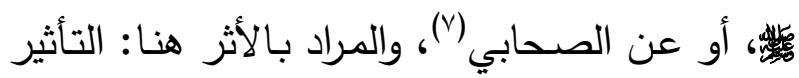

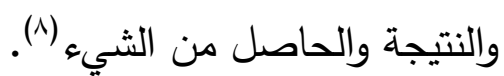
رابعاً: بيان المراد بـ (الاستقامة):

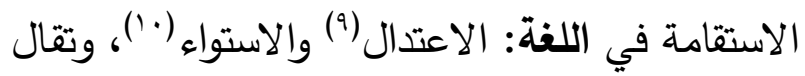

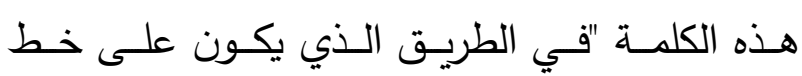

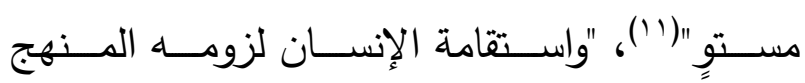

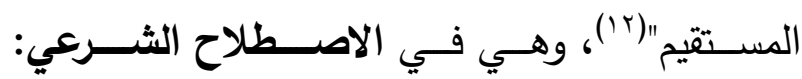
الاعتدال ومتابعة الكتاب والسنة، والبعد عن مجاوزة الحدودِ، والقيامُ بين يدي الله بالصدق والوفاء بالعهد،

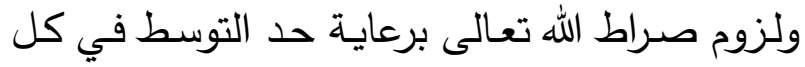

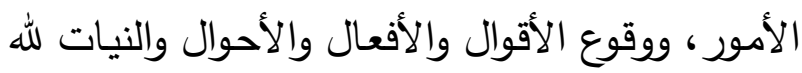

(1) انظر : المعجم الوسيط / (1) (مادة: أثر).

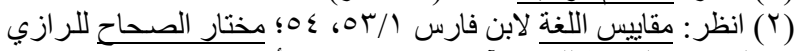

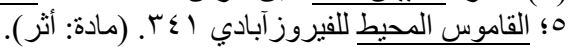

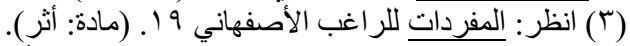

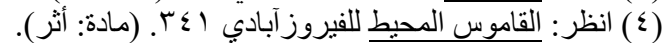

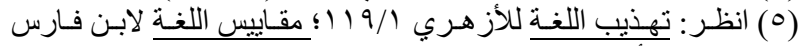

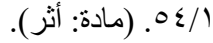

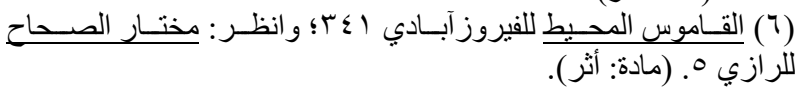

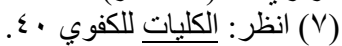

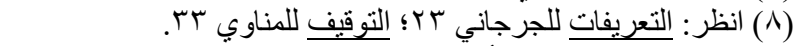

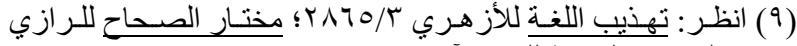

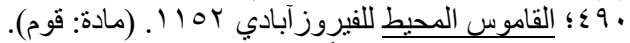

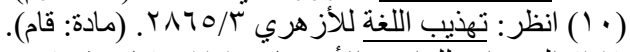

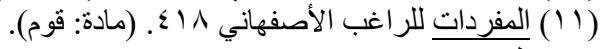

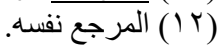


أخص صفات المؤمنين التي تميزهم عن المنـافقين

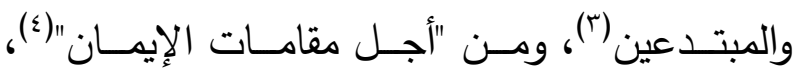
والمؤمن حقاً هو صساحب القلب السليم الخليّ عن شبهةٍ تفضي إلى معارضة الخبر ، وعن شهوة تفضي إلى معارضة الأمر (0). قال الإمام الشافعي رحمه الله: "لم أسمع أحداً نسبه الناس أو نسب نفسه إلى علمٍ يخالف في أن الله فرض اتباع أمر رسول الله بـ والتسليم لحكمه، وأن الله لم يجعل لأحدٍ بعده إلا اتباعه، وأنه لا يلزم قولّ بكل حال إلا بكتاب الله أو سنة رسول الله، وأن ما سواهما تبعُ لهما"(T)، وقال أيضاً: "إن الله تعبد خلقه لهابه في كتابه، وعلى لسان نبيه لَّل بما شاء، لا معقب لحكمه، فعلى الناس اتباع ما أُمروا به، وليس لهم فيه إلا التسليم" (V) وقال الإمام أحمد رحمه الله: "أجمع تسعون رجلًا من

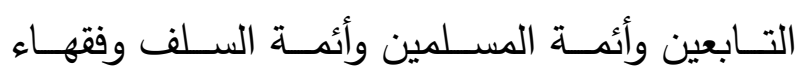
الأمصار على أن السُّنة التي توفي عليها رسول اللَّه

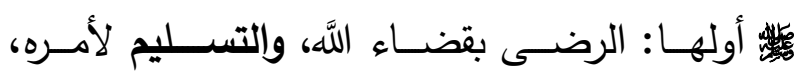

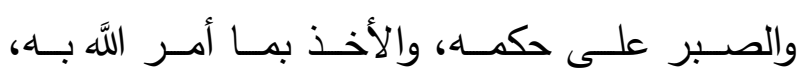
والانتهاء عما نهى عنه، والإيمان بالقدر خيره وشره، وترك المراء والجدال في الدين..."(^).

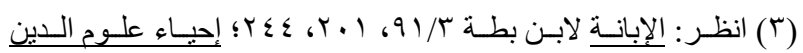

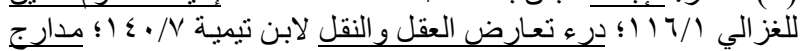

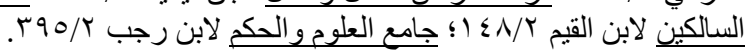

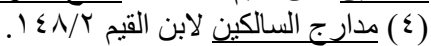

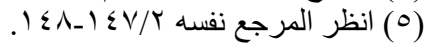

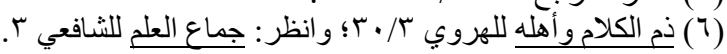
اختلاف الحديث للثافعي (V) (^)
الغيـب وأخبـاره، ومـا أجمـع عليـهـ السـلف الصــالح، والتسليم الله تعالى في الحكم والأمر والقدر والشرع، ولرسوله وتُلحظ في التعريـف الاصـلاحي المعـاني اللغويـة

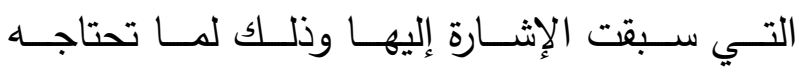
موضوعات العقيدة من الإحكام والإبرام وعزم القلب والتوكيد (r). سادساً: بيان المراد بـ (التسليم للنصوص الثرعية وأثره في استقامة العقيدة): مما تقدم يتضح أن المراد بعنوان الموضوع (التسليم للنصوص الثرعية وأثره في استقامة العقيدة) هو البحث في حكم الانقياد والإذعان لآيات القرآن الكريم وأحاديث السنة المطهرة، وأدلته، وثمرة ذلك ونتيجته وتأثيره في اعتدال اعتقاد الإنسان وصوابه، وصحة إيمانه، وتوسطه، وسلامته ونجاته من الضلال. المطلب الأول: حكم التسليم للنصوص الثرعية وأدلته

التسليم لأحكام الله تعالى ورسوله لئه ومـا جاءت بـه

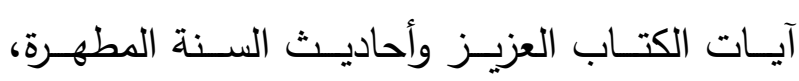
والإيمان بها، والانقياد لها، وتلقيها بانشراح الصدر ، والرضـى، وترك الإبـاء والاعتراض عليها هـو مـن أوجب الواجبات التي فرضـها الله على عبـاده، ومن ولن

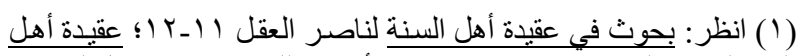

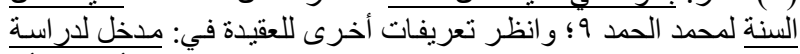

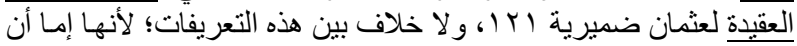

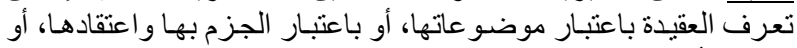

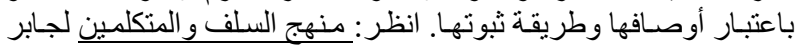

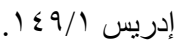
(Y) إنظر : شرح العقيدة الو اسطية لمحمد العثيمين //. •. 
1- قول الله تعالى: (( لله ما في السموات وما في الأرض وإن تبدوا ما في أنفسكم أو تخفوه يحاسبكم به الله فيغفر لمن يشاء ويعذب من يثاء والله على اللى

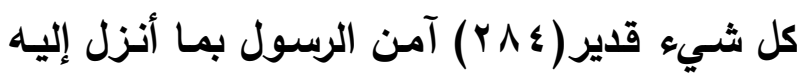

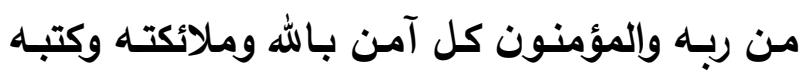
ورسله لا نفرق بين أحد من رسلـه وقالوا سمعنا

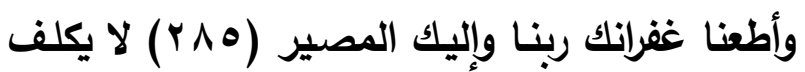

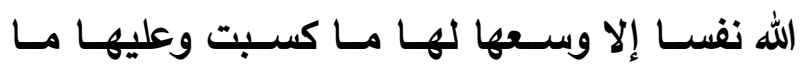
اكتسبت ربنا لا تؤاخذنا إن نسينا أو أخطأنا ربنا ولا ولا تحمل علينا إصراً كما حملته على الذين من قبلنا

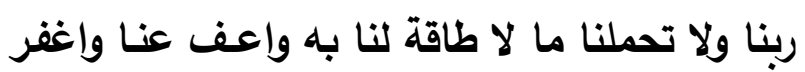

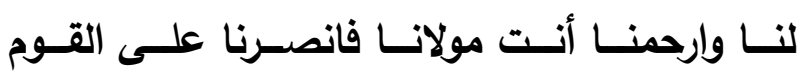
(الكافرين)(م)

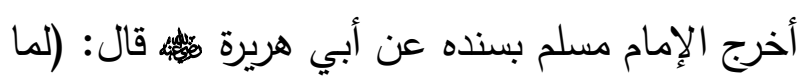

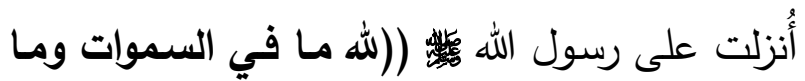
في الأرض وإن تبـدوا مـا في أنفسكم أو تخفـوه

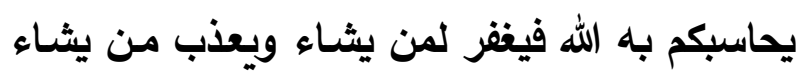

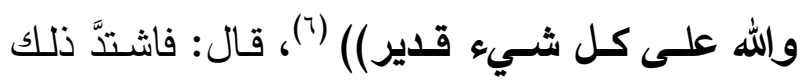
على أصـحاب رسـول الله 

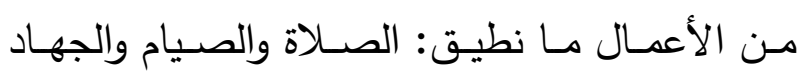

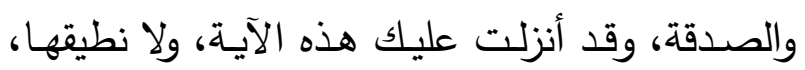
فقال رسول الله الكتابين مـن قبلكم: سـمعنا وعصينا؟. بـل قولـوا:
وقال ابن بطة(') رحمه الله عن أحاديث الصفات:

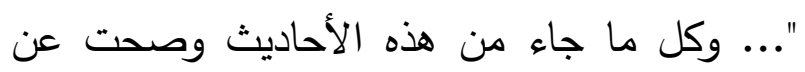

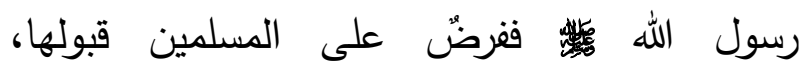
والتصديق بها، والتسليم لها، وترك الاعتراض

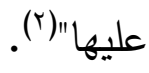
وقال قوام السنة(") رحمه الله: "ومن مذهب أهل السنة أن كل ما سمعه المرو من الآثار مما لم يبلغه عقله... فعليه التسليم والتصديق..."(؛). وأدلة وجوب التسليم للنصوص الشرعية كثيرةٌ ظاهرةٌ

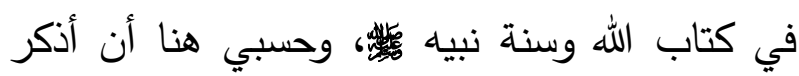
بعض تلك الأدلة. بعضض أدلـة القــرآن الكـريم علـى وجـوب التسـليم للنصوص الثرعية: أوجب ربنا جل وعلا التسليم لكلامه وكلام رسوله في عدة آيات كريمة، أعرض فيما يلي بعضها ووجها

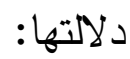

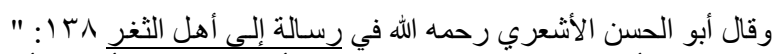

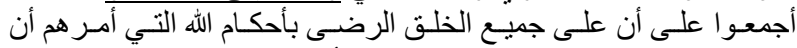

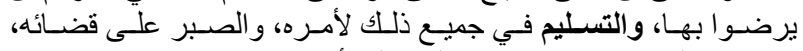

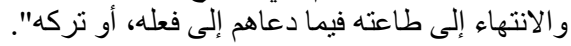

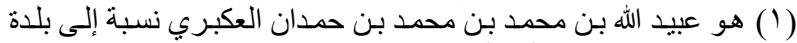
قرب بغداد، وبطة لقبّ لأحد أجداده، من تصانيفه: الإبانة الكبرى، والئن والإبانة

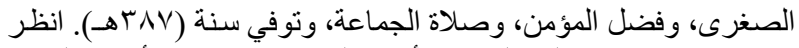

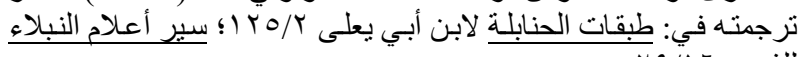
اللذهبي (Y) (r) الإبانة

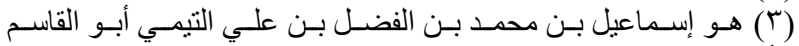

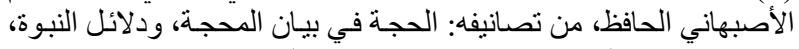

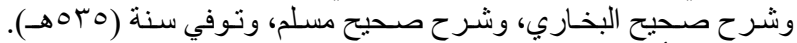

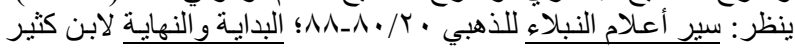
r T $Y / T$ ( ) (الحجة 


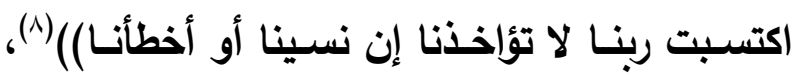

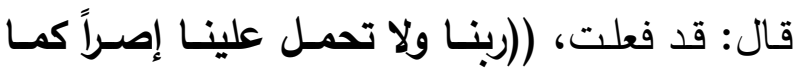

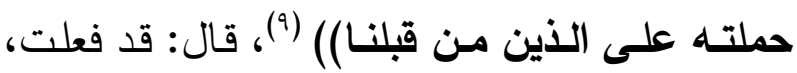

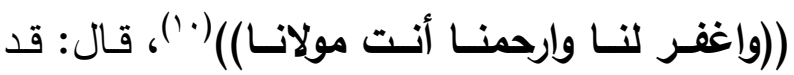

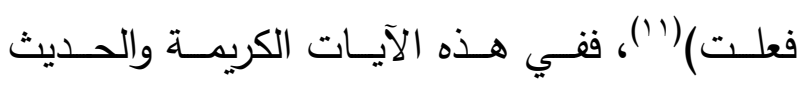

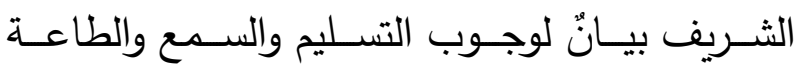
والانقياد لأحكام الله تبارك وتعالى، وبيان لثرة ذلك التسليم والانقياد، من التخفيف ورفع الحرج والآصار ومغفرة الذنوب والعفو والرحمـة والنصر ، وبيانٌ لـ"ما

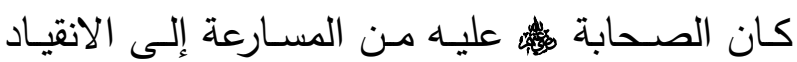

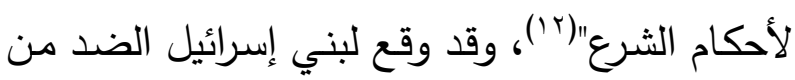

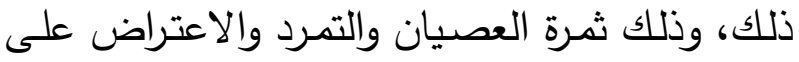

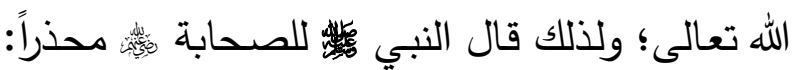

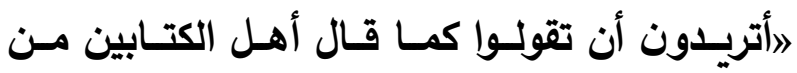
قبلكم: سمعنا وعصينا؟. بل قولـوا: سمعنا وأطعنـا

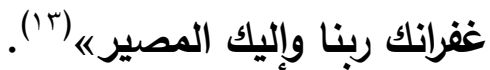
ץ- قول الله تعالى مخاطباً نبيه يؤمنون حتى يحكموك فيما شجر بينهم ثم لا يجدوا

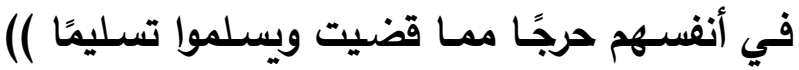

فبـين الله تعـالى أن طاعـة رسـوله

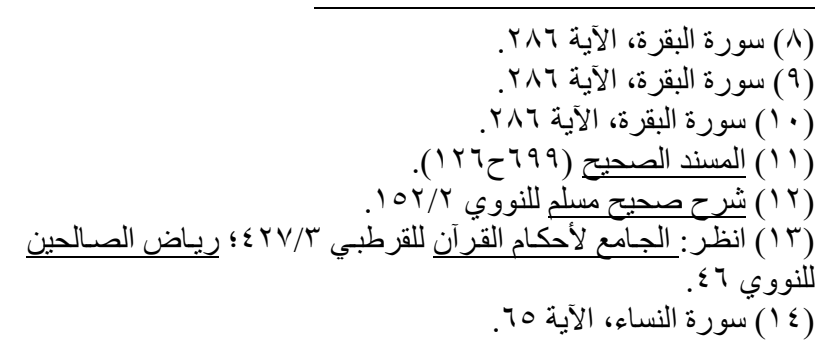

سمعنا وأطعنـا غفرانك ربنـا وإليك المصيره، قالوا: سـمعنا وأطعنــا غفرانـك ربنـا وإليـك المصـير ، فلمــا

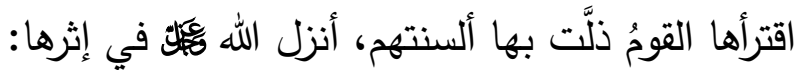
(آمن الرسول بما أنزل إليه من ربه والمؤمنون كل آمن بالله وملائكته وكتبه ورسله لا نفرق بين أحد الحد

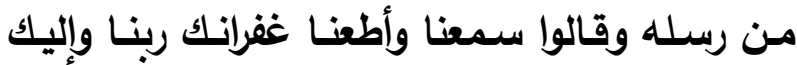
(المصير))(')، فلما فعلوا ذلك نسخها الله تعالى، فأنزل

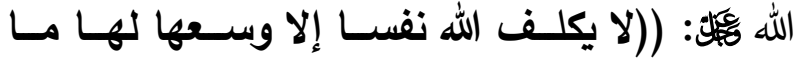
كسبت وعليها ما اكتسبت ربنا لا تؤاخذنا إن نسينا

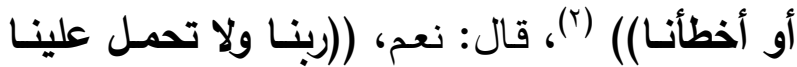

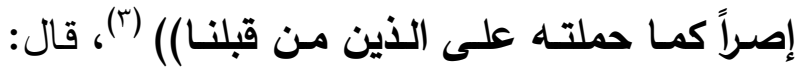

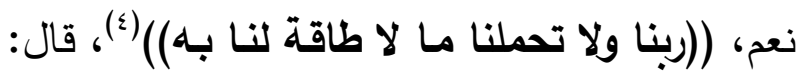
نعم،((واعـف عنـا واغفر لنـا وارحمنـا أنت مولانـا

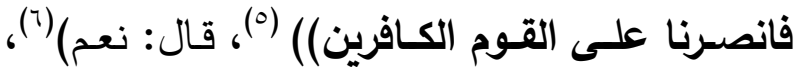
وفي رواية أخرى لله عن ابن عباس رضي الله عنهما

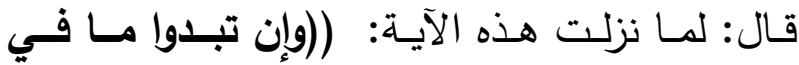

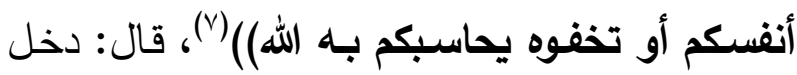
قلوبهم منها شيءٌ لم يدخل قلوبهم من شيءٌ، فقال

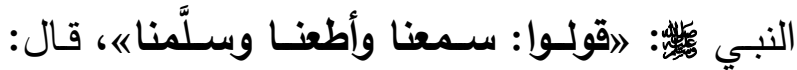

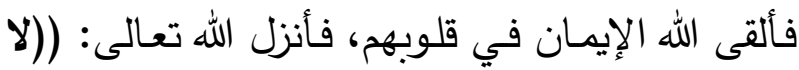

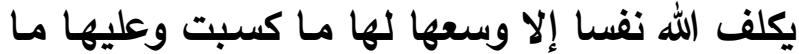

(1) سورة البقرة، الآية همبح.

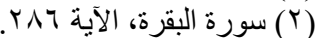

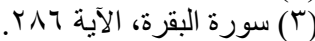

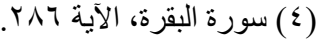

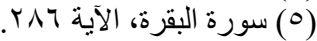

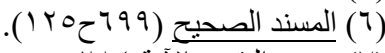


على العموم، وهو قوله: (( فيما شجر بينهم)) أي:

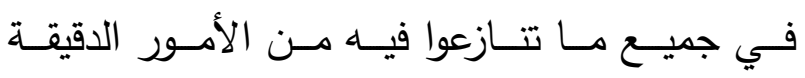

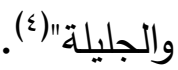
• أنه أكد المعنى بتعليق حصول الإيمان على التسليم لحكم الرسول

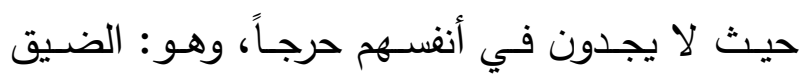

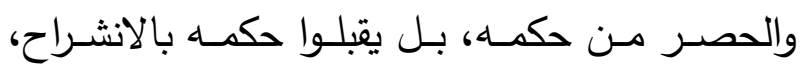

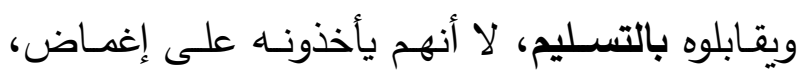
ويشربونه على قذى، فإن هذا منافٍ للإيمان، بل لا لا لإنها

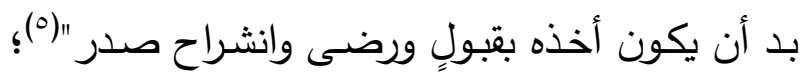

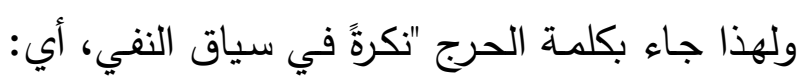
لا يجدون نوعاً من أنواع الحرج البتة"(؟). • تأكيد ذلك التسليم بذكر المصدر بعد ذكر الفعل نواعل

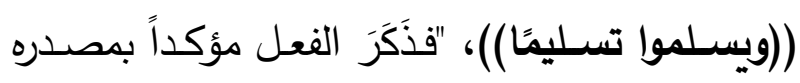

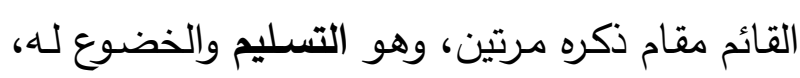
والانقياد لما حكم به طوعاً ورضى وتسليماً، لا قهراً

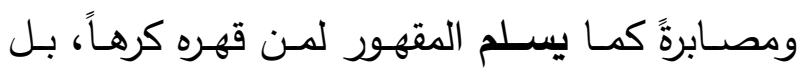

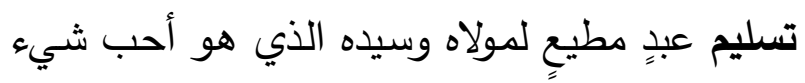
إليه، يعلم أن سعادته وفلاحه في تسليمه إليهاه، ويعلم

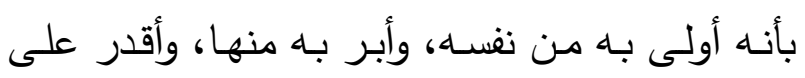

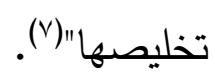
ومـا ذكر الله في الآية كل هذه المؤكِدات "إلا لشدة

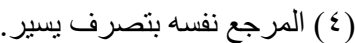

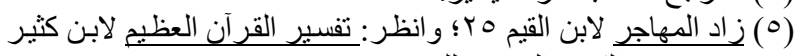

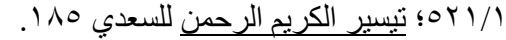

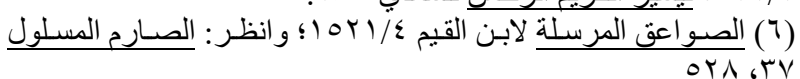

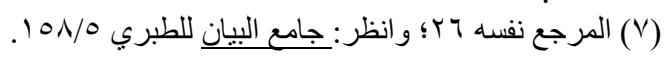

المؤمنين، وأنهم لا يكونـون مـؤمنين إلا بــلك، وأن

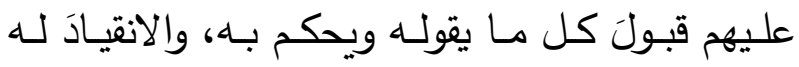

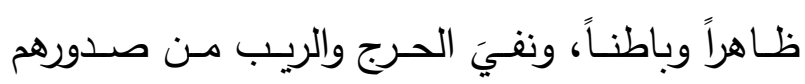

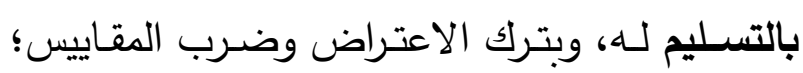

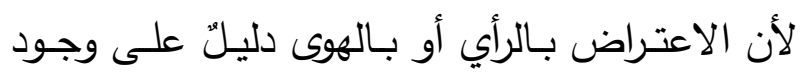

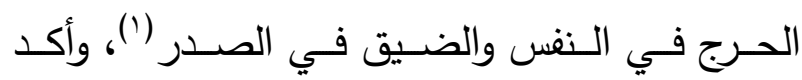
سبحانه وجوب التسليم لحكم رسوله

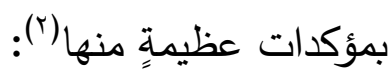
أنـهـ تعـالى صـدر الآيـة بالقسـم المؤكِّد لـــا

تضمنته.

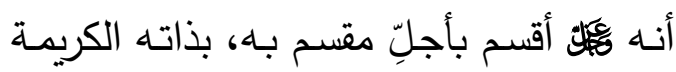

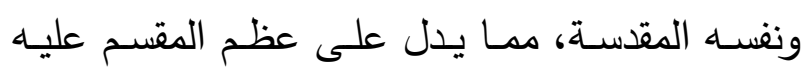
وخطورته، ولا يعرف مضدونَ هذا إلا أولو البصائر . تصدير جملة القسم بلا النافية (( فـلا وربك لكبك )) قبل قوله: (( لا يؤمنون )) تأكيداً للنفي وإظهاراً لقوته وشدة انتفاء المقسم عليه. "أنــ أتى في الغايـة بــ(( حتـى ()) دون إلا،

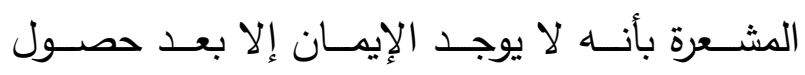
التحكيم؛ لأن ما بعد حتى يدخل فيما قبلها"(").

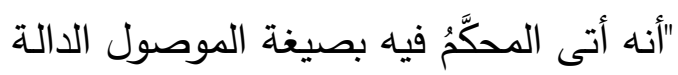

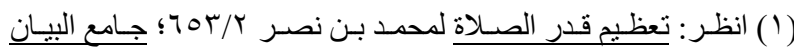

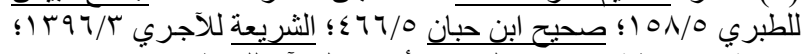

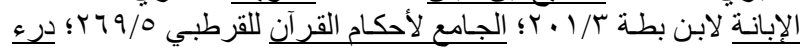

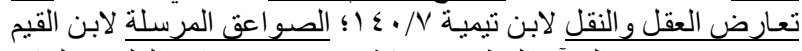

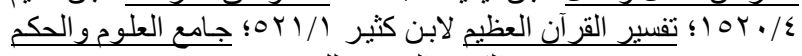

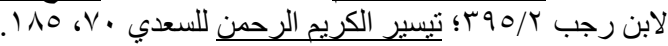

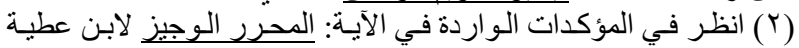

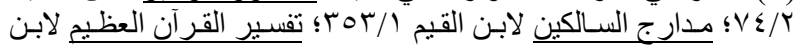

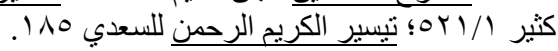

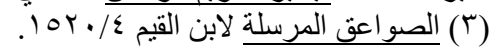


r- قول الله تعالى: ((هو الذي أنزل عليك الكتاب منه آيات محكمات هن أم الكتاب وأخر متثـابهات فأما الأين في قلوبهم زيـغ فيتبعون مـا تثـابه منـه ابتغاء الفتنة وابتغاء تأويلـه ومـا يعلم تأويلـه إلا الله والراسخون في العلم يقولون آمنـا بـه كل من عند ربنا وما يذكر إلا أولوا الألباب)() (^). فقد دلت هذه الآية على أن الراسخين في العلم الذين أثنى الله تعالى عليهح يتلقون نصوص الكتاب كلها بالإيمان والتصديق ويقولون عن المحكم والمتشابه: ((آمنا به كل من عند ربنا)()، وهذا "كلامٌ يُشعر بالتقويض والتسليم لما لم يعلموه؛ لعلمهم بأنه من

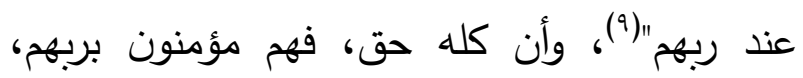
واثقون به، مسلّمون لأمره، موقنون بأنه صدر منه؛ ولهذا صدَّروا كلامهم بلفظ الإيمان، وذكروا كلمة الرب مضافةً إليهم، "فذكرهم ربَّهم هاهنا يعطي الثقة باه، والتسليم لأمره، وأنه صدر منه، وجاء من عنده،

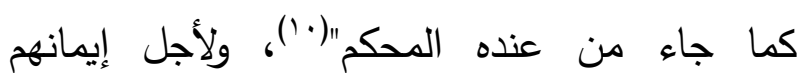

ظاهره، ما لم يعارضه دليل آخر... و هذا هو الذي لا بسع أحدا غيره، فال

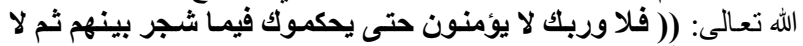

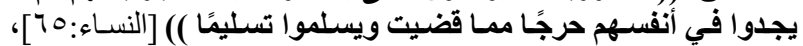

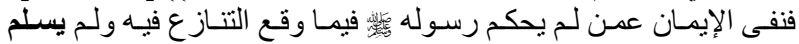

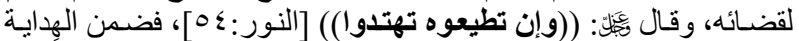

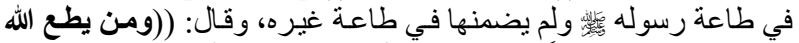

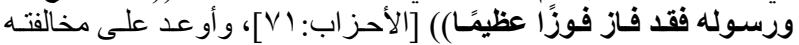

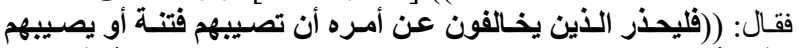

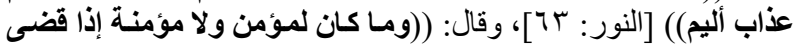

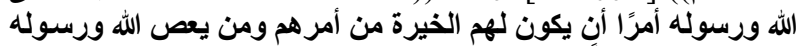

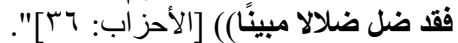

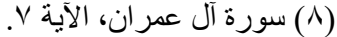

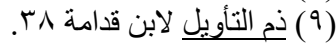

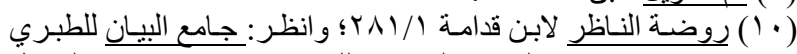

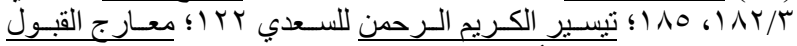

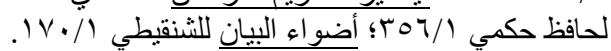

الحاجة إلى هذا الأمر العظيم، وأنها مما يُعتنى به، ويُقرَّر في نفوس العباد بما هو أبلغ أنواع التقرير" ('). ولما كان حكُ رسول الله النبي (إن لا ينطق عن الهوى، ((إن هـو إلا وحي يوحى)) (ז)، وقد قال الله تعالى: ((من يطع الرسول لهول

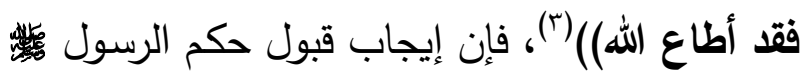

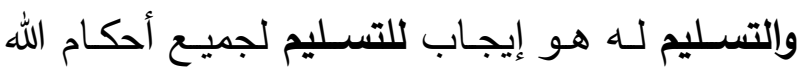
تعالى سواءٌ مـا ورد منها في الكتاب العزيز أو في لهي

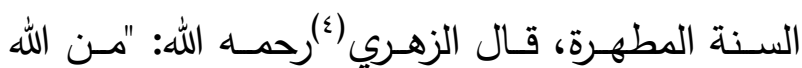

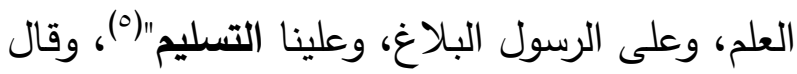

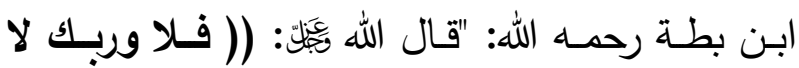
يؤمنون حتى يحكموك فيما شجر بينهم ثم لا يجدوا

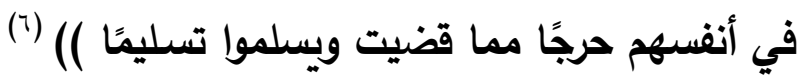

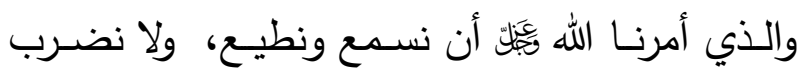

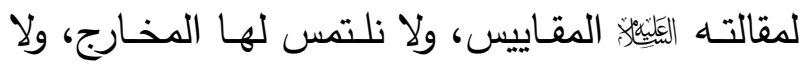
نعارضها بالكتاب، ولا بغيره، ولكن نتلقاهـا بالإيمان

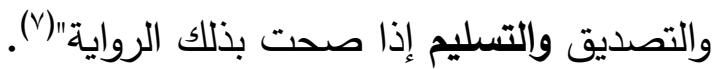

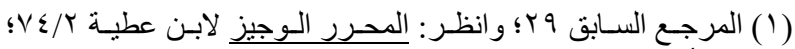

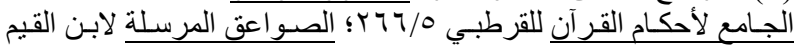

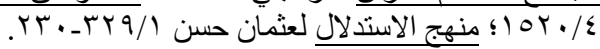

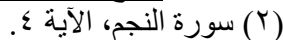

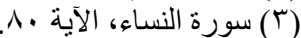

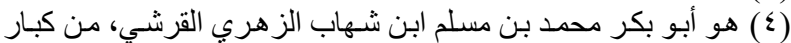

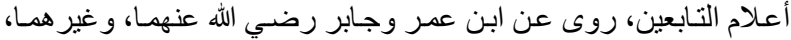

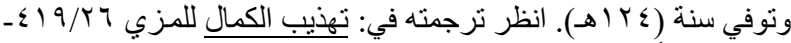

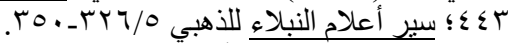

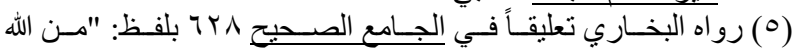

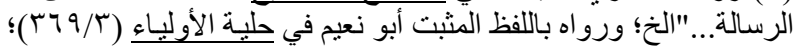

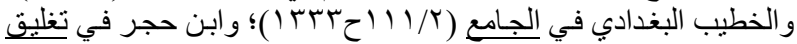
التعليق (T0/0)

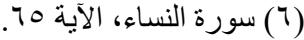

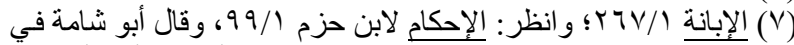

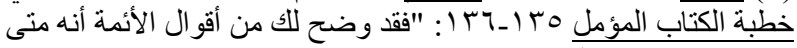

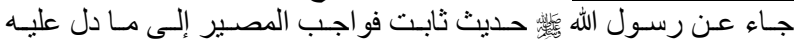
$=$ 
وتسليمهم امتدحهم الله وجعلهم في درجة الرسوخ في مبينًا)) (").

فقطع الله تعالى في هذه الآية الكريمة العامة التخييزَ

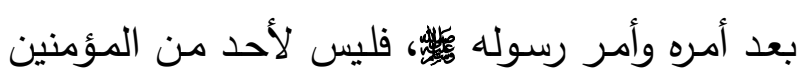

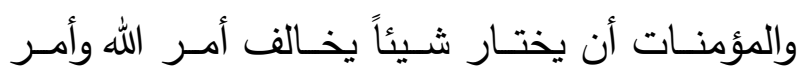
رسوله

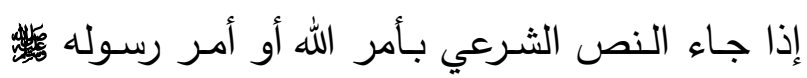

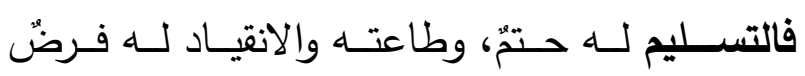

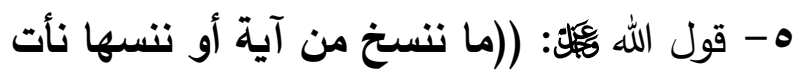

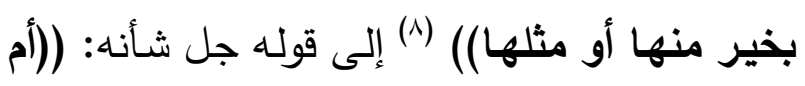
تريدون أن تسألوا رسولكم كما سئل موسى من قبل قبل

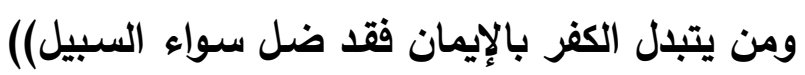

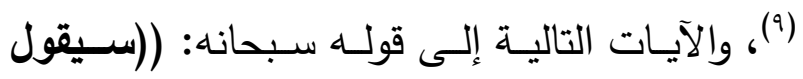
السفهاء من الناس ما ولاهم عن قبلتهم التي كانوا

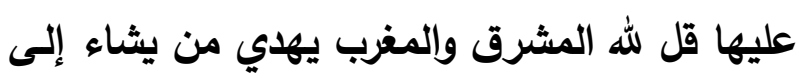
صراط مستقيم (Y \& 1 ) وكذلك جعلناكم أمسة وسطًا لتكونوا شـهاء على الناس ويكون الرسول عليكم شـهيدًا ومـا جعلنا القبلة التي كنت عليهاء إلا لنعلم من يتبع الرسول ممن ينقلب على عقبيه وإن كانت

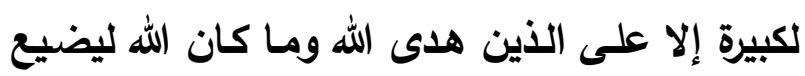

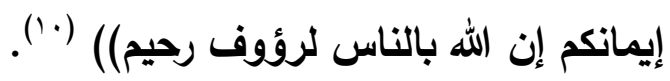

(T) سورة الأحز اب، الآية بس.

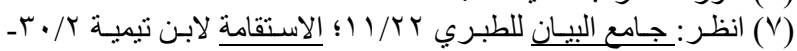

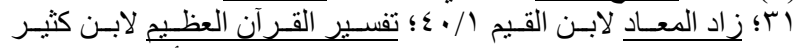

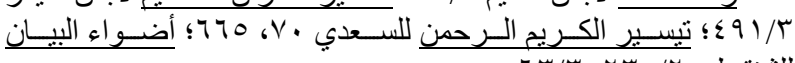
اللشنقيطي

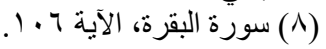

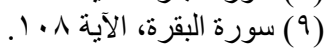

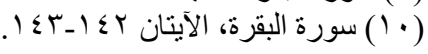
العلم، أي: الإتقان والوعي والحفظ دون شك ولا لإنا لبس (')، قالت أم المؤمنين عائشة رضي اللقان والوعي والهنه دنها:

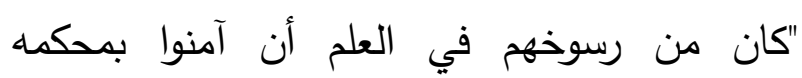

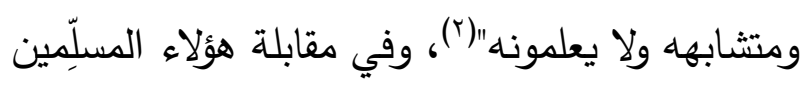

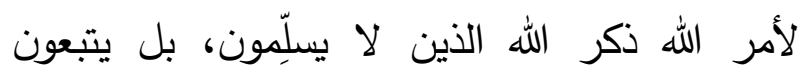

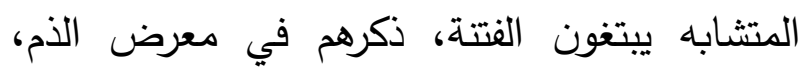
وسمى فعلهم زيغاً، أي: ميلاً عن الحق(")؛ تحذيراً

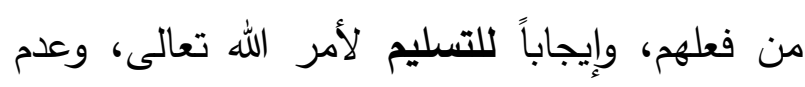

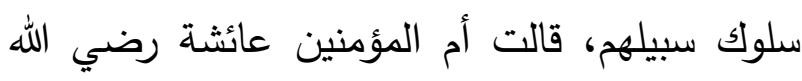

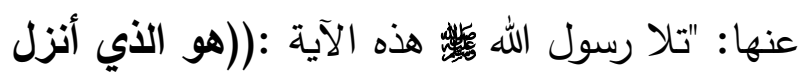

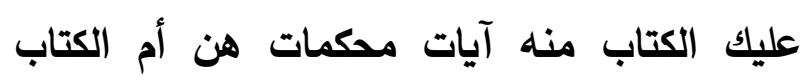
وأخر متثابهات فأما الذين في قلوبهم زيغ فيتبع التهون ما تثابه منه ابتغاء الفتنة وابتغاء تأويله وما يعلم

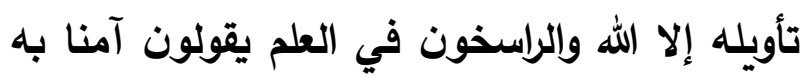

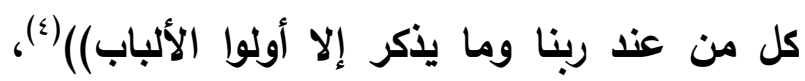

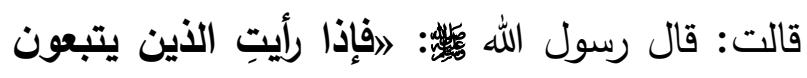

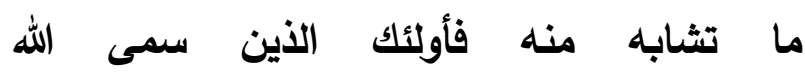
فاحذروهمب (0).

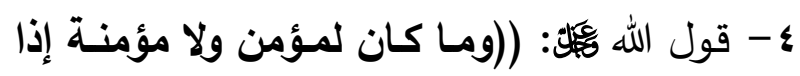

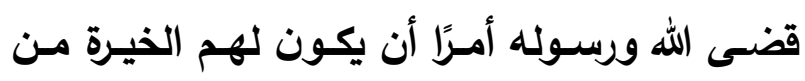

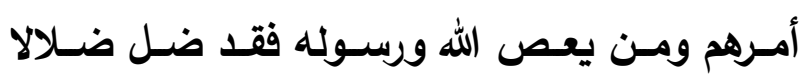

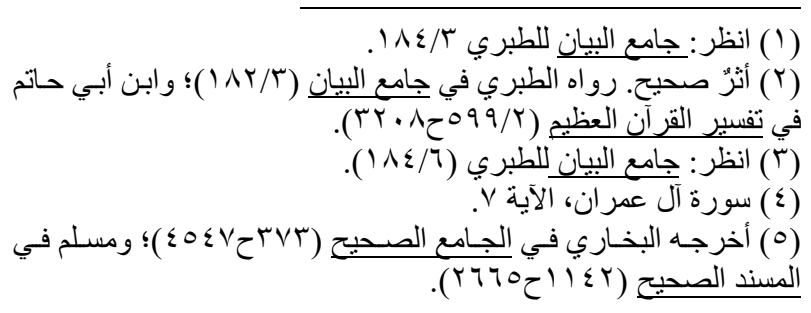


للرسول، المنقاد لله، ممن يعبد الله تعالى على حرفٍ فينقلب على عقبه بأدنى شبهة"(r).

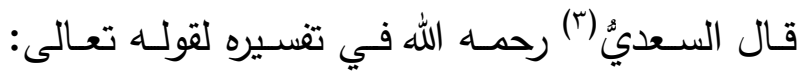
(سيقول السفهاء من الناس ما ولاهم عن قبلتهم

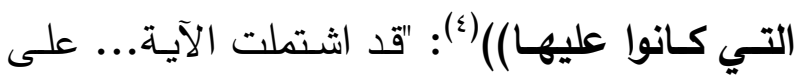
معجزة، وتسليةٍ، وتطمين قلوب المؤمنين، واعتراض، وجوابـه مـن ثلاثة أوجـه، وصـفة المعترض، وصـفة المسلِّم لحكم الله ودينه، فأخبر تعالى أنه سيعترض فله السفهاء مـن النـاس، وهـم الذين لا يعرفون مصـالح أنفسـهم بـل يضـيعونها ويبيعونها بـأبخس ثـن، وهـم اليهود والنصسارى ومن أشبههم من المعترضين على أحكام الله وشرائعه، وذلك أن المسلمين كانوا مأمورين باسـتقبال بيـت المقـدس مـدة مقـامهم بمكـة ثم بعـد الهجرة إلى المدينـة نحو سنة ونصف؛ لما لله تعالى في ذلك من الحكم التي سيشير إلى بعضها، وكانت

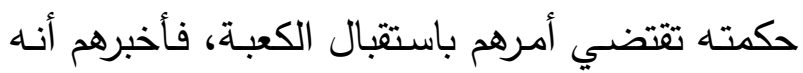
لا بـد أن يقول السـفهاء مـن النـاس: مـا ولاهـم عـن قبلتهم التي كانوا عليها؟ وهي استقبال بيت المقدس: أي شـيء صـرفهم عنـه؟ وفي ذلك الاعتراضُ على حكم الله وشـرعه وفضـله وإحسـانه، فسـلاهم، وأخبـر بوقوعـه، وأنــه إنمـا يقـع مدـن اتصـف بالسـفه، قليـل العقـل والحلـم والديانـة، فـلا تبـالوا بهـم؛ إذ قـد عُلـم

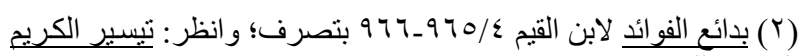

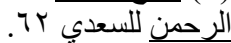

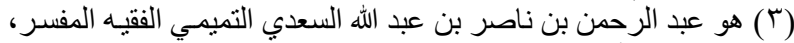

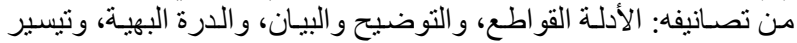

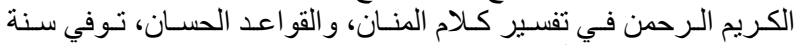

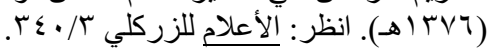

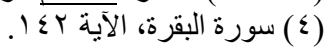

فقد جـاءت الآيتـان الكريمتـان الأوليـان في سـياق التمهيد الذي قدم الله تعالى به بين يدي تحويل القبلة

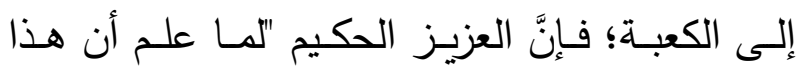

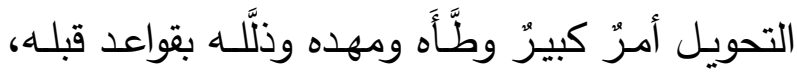

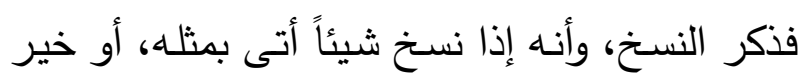
منه، وأنه قادر على ذلك فلا يعجزه، ثم قرر التسليم

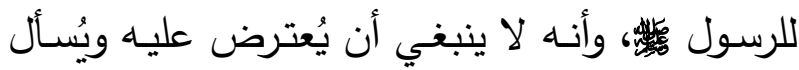

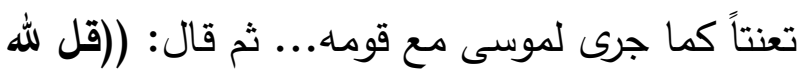
المشــرق والمغـرب يهـدي مسن يثــاء إلسى صـراط

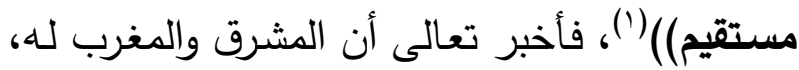

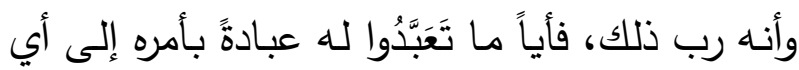

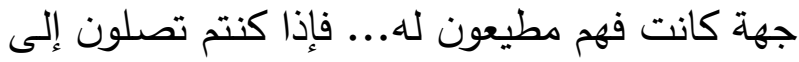

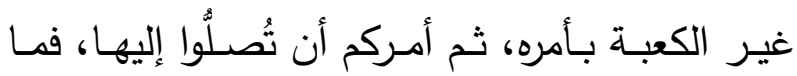

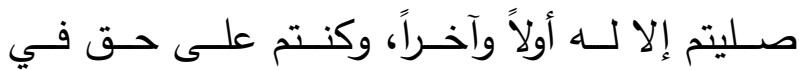
الاسـتقبال الأول والآخِـر ؛ لأن كليهـــا كـان بـأمره ورضـاه، فانتقلتم من رضـاه إلى رضـاه، ثم نبـه على لانى

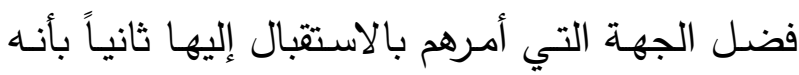
يهدي من يشاء إلى صراط مستقيم، كما هداكم للقبلة

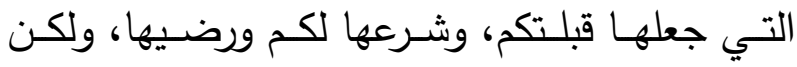

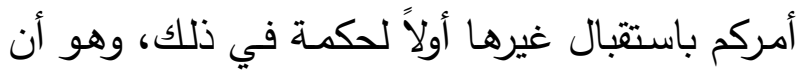
يعلم سبحانه من يتبع الرسـول، ويـدور معـه حيثـا

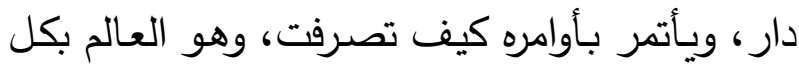
شـيء، ولكـن شـاء أن يعلـم معلومــه الغيـبي عيانـاً

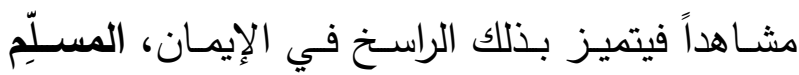


والطاعة لله والرسول كإ: بالفتنة من الكفر أو النفاق

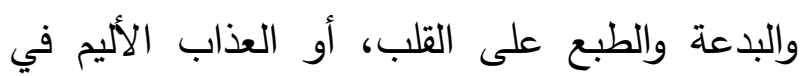
الدنيا والآخرة، وهذا دليلٌ على أن طاعة رسول الله  ومع هذه الأدلة الدالة على وجوب التسليم لأمر الله

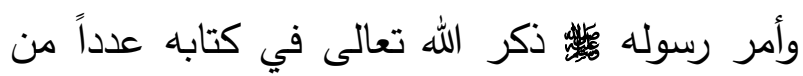
مواقف التسليم لأمره والانقياد لحكمه التي وقفها صفوة خلقه وفضلاؤهم أذكر منها ثلاثة مواقف فيما

1- ما ذكره ربنا عن موقف خليله إبراهيم وابنه إسماعيل عليهما الصلاة والسلام لما رأى إبراهيم في المنام أنه يذبح ابنه في قوله سبحانه: ((فبشرناه بغلام حليم (1 ـ 1) فلما بلغ معه السعي قال يا بني

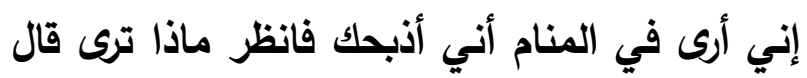

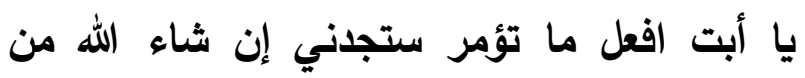

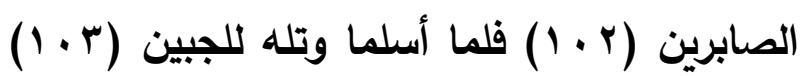
وناديناه أن يا إبراهيم (ع ـ 1) قد صدقت الرؤينا إنا

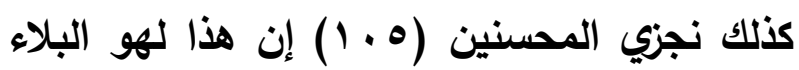

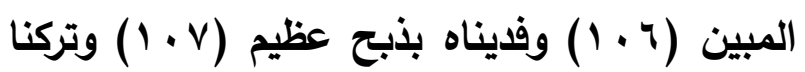
عليه في الآخرين (1.1) سلام على إبراهيم

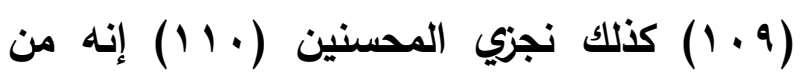
عبادنا المؤمنين)(·(')، فذكر الله تعالى في هذه الآيات تسليم هذين النبيين الكريمين عليهما الصلاة

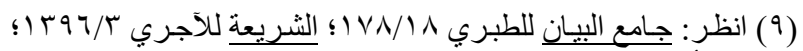

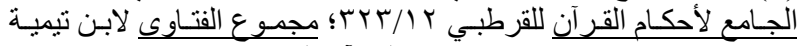

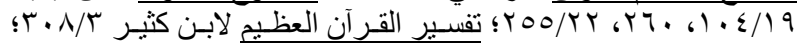

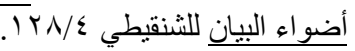

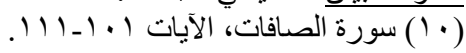

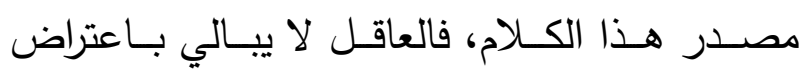

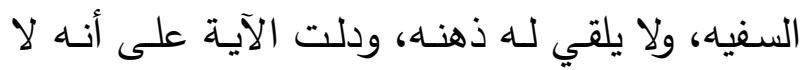
يعترض على أحكام الله إلا سفيهُ جاهلٌ معاندُ، وأمـا

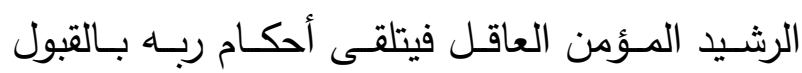
والانقياد والتسليم"('). צ- قول الله جل شأنه: ((إنمـا كـان قول المؤمنين إذا دعوا إلى الله ورسـوله ليحكم بيـهم أن يقولــوا

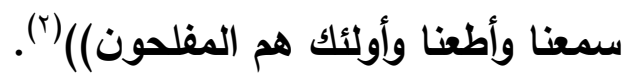
فقد حصر الله في هذه الآية الكريمة "قولَ المؤمنين

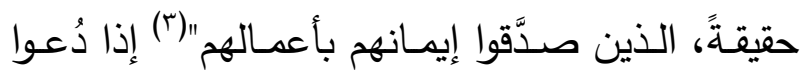

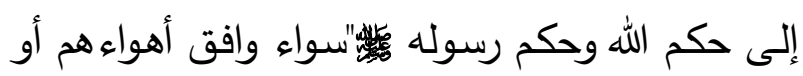

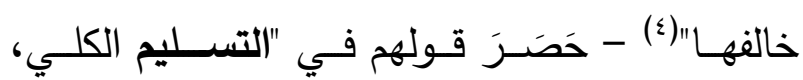

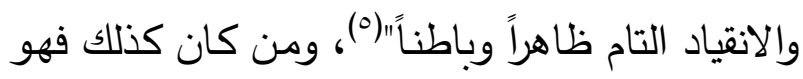
موصوف "بالفلاح، وهو نيل المطلوب، والسـلامة من ونس

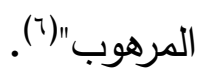
- قول الله تعالى: ((فليحذر الذين يخـالفون عن أمره أن تصييهح فتنة أو يصيبهم عذاب أليم)) (V)

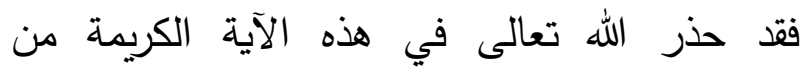

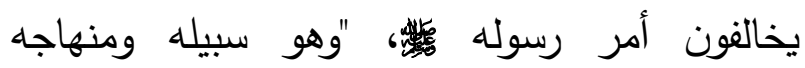

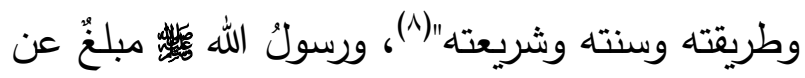
ربه أمره، وتوعدهم في حال المخالفة وعدم التسليم

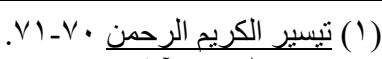

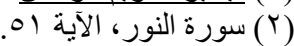

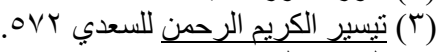

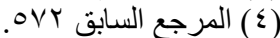

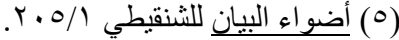

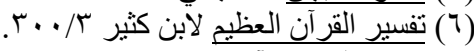

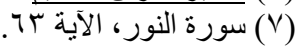

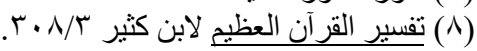


لها العقول، ولو كُشف للناس عن أصولها لجاءت للناس واضحةً بينة غير مشكلة على مثل ما جاء عليه أمر السفينة وأمر الغلام وأمر الجدار ... ومن مأن أجهل وأضل وأقل معرفة بحق الله وحق رسوله وبنور الإسلام وبرهانه ممن قال لا أقبل سنة ولا أمراً مضى من أمر المسلمين حتى يُكثف لي غيبه وأعرف أصوله؟ أو: لم يقل ذلك بلسانه فكان عليه رأيه وفعله"(0). وقـال ابـن بطـال (־) رحمـهـ الله: "في قصــة الخضـر أصلٌ عظيمٌ من أصول الدين؛ وذلك أن ما تعبَّدَ الله به خلقه من شريعته ودينه يجب أن يكون حجة على الى الى

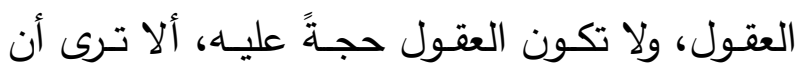
إنكـار موسـى على الخضــر خـرق السـفينة، وقتـل الغـلام كان صـوابًا في الظـاهر ، وكان موسـى غير ملوم في ذلك، فلمـا بَيَّن الخضـر وجـه ذلك ومعنـاه صسار الصواب الذي ظهر لموسىى من إنكاره خطأ، وصسار الخطأ الذي ظهر لموسىى من فعل الخضر صوابًا، وهذا حجةٌ قاطعة في أنه يجب التسليم لله في

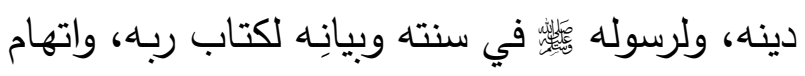
العقول إذا قصرت عن إدراك وجه الحكمة في شيء من ذلك؛ فإن ذلك محنة من الله لعباده، واختبار لهم؛

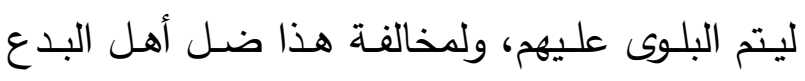
حين حكموا عقولهم وَرَدُّوا إليها ما جهلوه من معاني

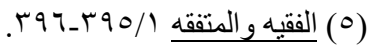

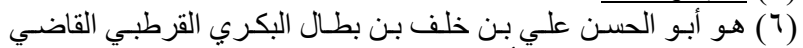

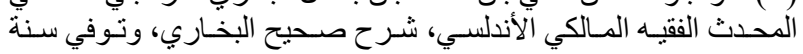

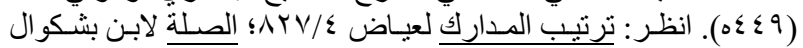

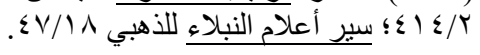

والسلام لأمر الله، فقال الابن لأبيه: ((يا أبت افعل

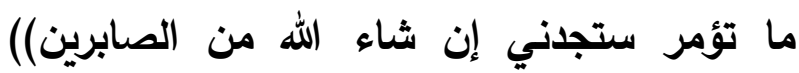

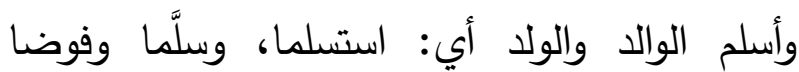
وأطاعا أمر الله|'، كما قال سبحانه: ((فلما أسلما وتله للجبين))، وفي قراءة عبد الله بن مسعود الهابه: فلما سلَّما (r). r - ما ذكره الله سبحانه في قصة موسى والخضر عليهما السلام وفي آخرها قول الخضر : ((وما فعلته عن أمري ذلك تأويل ما لم تسطع عليه صبرًا)(") (َ).

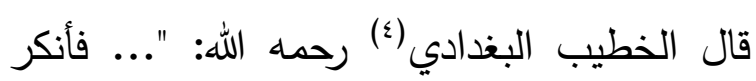
موسى ذلك عليه، وجاء ذلك في ظاهر الأمر منكراً

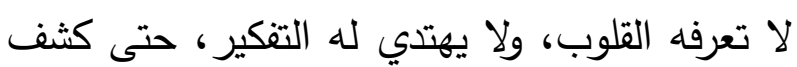

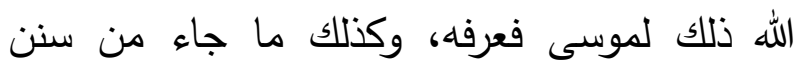
الإسلام وشرائع الدين التي لا توافق الرأي، ولا تهتدي

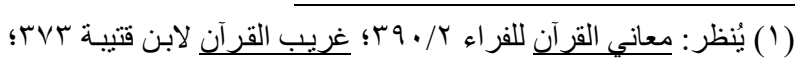

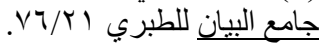

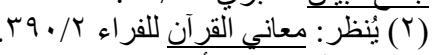

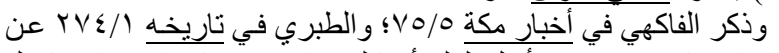

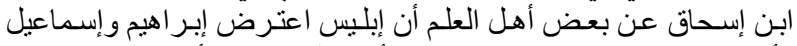

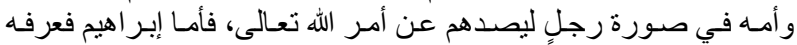

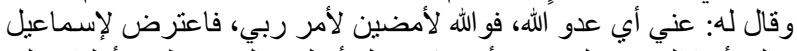

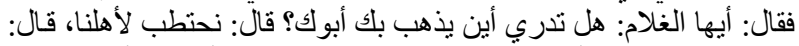

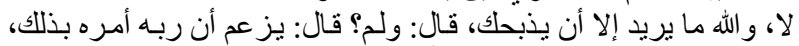

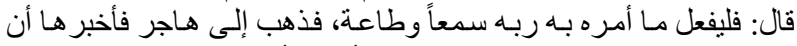

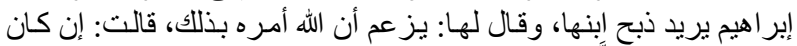

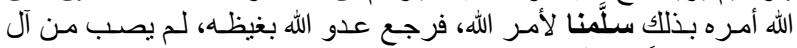

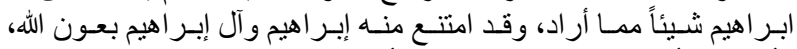

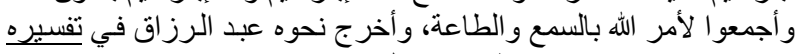

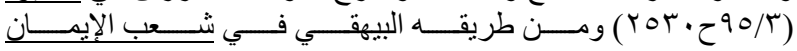

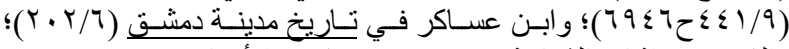

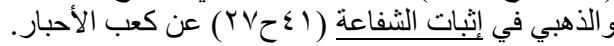

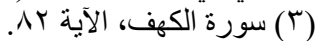

( ) هو أبو بكر أحمد بن علي بن ثابت بن مهدي الخطيب البغدادي،

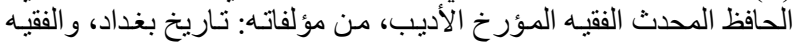

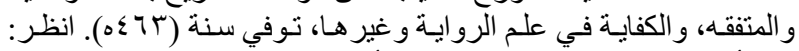

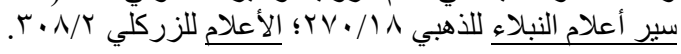


وأحزابهم، ولكنهم سلموا لربهم أمره وقضـاءه، وثبتوا

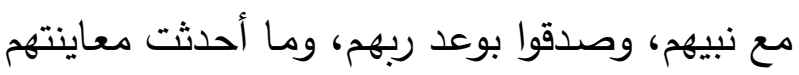

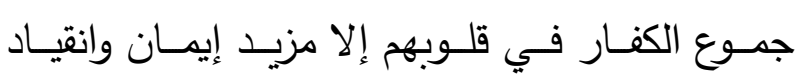
وتسليم ورضى (ج)، "وفي ذلك أتم ثناءٍ على الصحابة الصابة

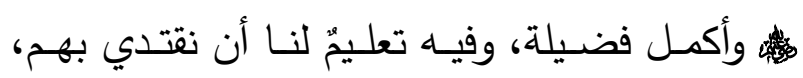

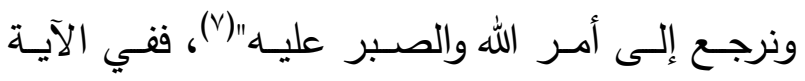

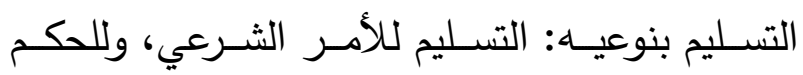
القدري. بعض أدلــة الســنة النبويـة علـى وجـوب التسـليم للنصوص الثرعية: تزخر السـنة النبويـة المطهرة بالعديد مـن الأحاديـث الدالة على هذا الأصل ومنها:

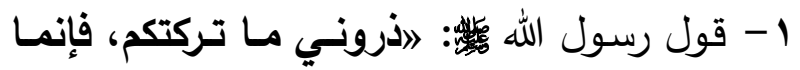
هلك من كان قبلكم بكثرة سيؤالهم واختلافهم على هلى

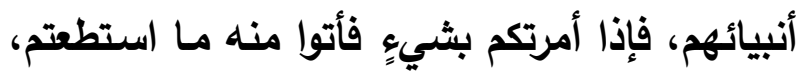
وإذا نهيتكم عن شيء فدعوهی) (^). في هذا لقدي

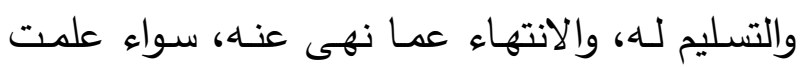

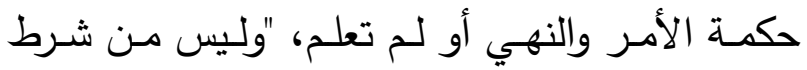
المولى مـع العبد أن يفهم المقصود بجميع مـا يأمره

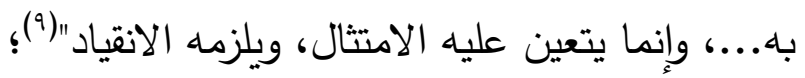

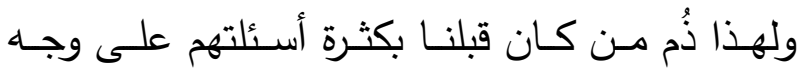

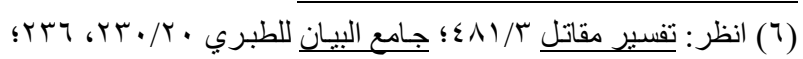

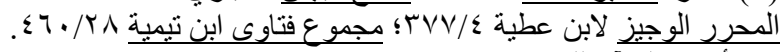

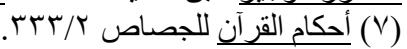

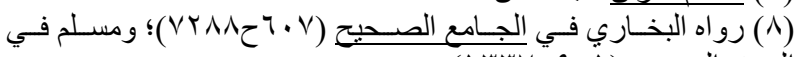

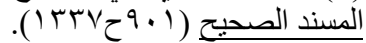

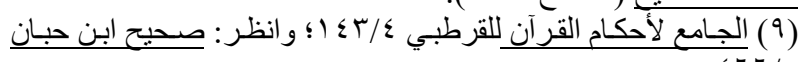

القدر وشبهه، وهذا خطأ منهم؛ لأن عقول العباد لها

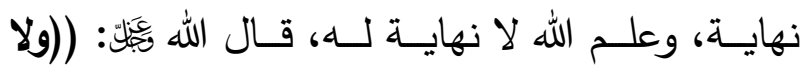
يحيطون بشيء من علمه إلا بما شاء)('(')("().

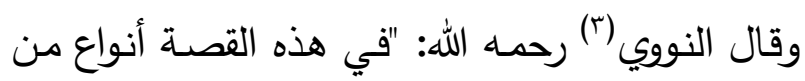

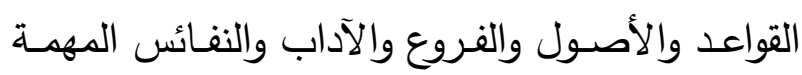
... منها بيان أصل عظيم من أصول الإسـلام، وهو ولادول

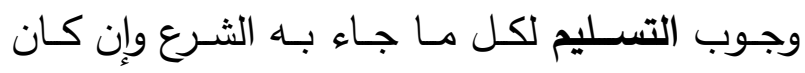
بعضـه لا تظهر حكمته للعقول.... موضـع الدلالـة:

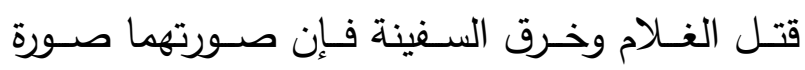
المنكر وكان صحيحاً في نفس الأمر له حِكمٌ بينة

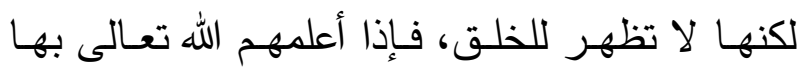
علموها؛ ولهذا قال: ((وما فعلته عن أمري))، يعني: بل بأمر الله تعالى" (؟). r- ما ذكره الله تبارك وتعالى عن موقف أصحاب نبيه سبحانه: ((ولما رأى المؤمنون الأحزاب قالوا هذا ما فال فئ وعدنا الله ورسوله وصدق الله ورسوله وما زادهم إلا

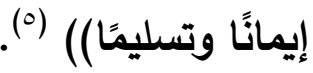

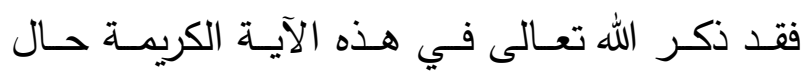
أصحاب نبيه تثبيطهم عن الجهاد، وتخويفهم من جموع المشركين

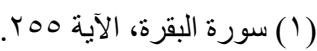

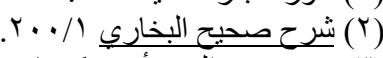

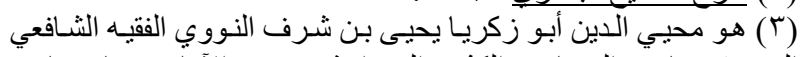

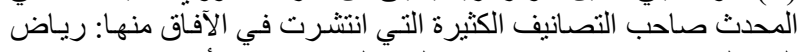

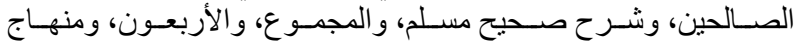

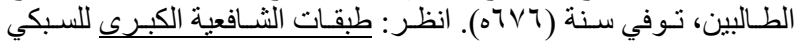
18/1

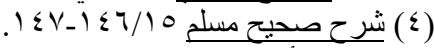
(0) سورة الأحزاب، الآية برحيل 


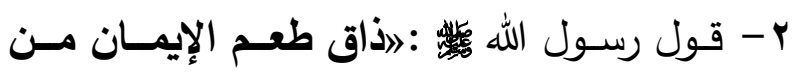

رضي بالله رباً، وبالإسـلام ديناً، وبمحمد رسولاًٍ (". ففي هذا الحديث الشريف بيان أن الإيمان لا يذاق طعمه إلا بالرضى "بربوبيته سبحانه، وألوهيته،

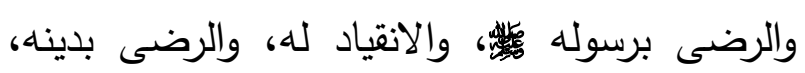
والتسليم له"(๕)، ورضى العبد بربوبية الله تعالى برسئ وإلهيته يتضمن الرضى بما يأمره به، وبما يقدره

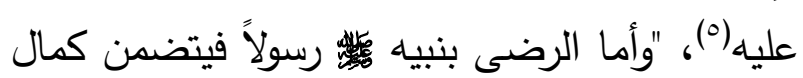
الانقياد له، والتسليم المطلق إليه، بحيث يكون أولى والى باه من نفسه، فلا يتلقى الهدى إلا من مواقع كلماته، ولا يحاكم إلا إليه، ولا يحكّمٍ عليه غيره، ولا يرضى إله بحكم غيره البتة، لا في شيء من أسماء الرب وصفاته وأفعاله، ولا في شيء من حقائق الإيمان، ولا في شيء من أحكام الدين الظاهرة والباطنة، وأما الرضى بدينه فإذا قال أو حكم أو أمر أو نهى رضي الهي كل الرضى، ولم يبق في قلبه حرجٌ من حكمه، وسلم له تسليماً، ولو كان مخالفاً لمراد نفسه أو هواها، أو قول مقلده وشيخه وطائفته"(؟).

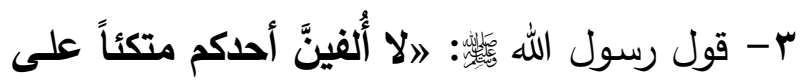
أربكتـه يأتيـه الأمـر ممـا أمرت بـه، أو نهيـت عنـه،

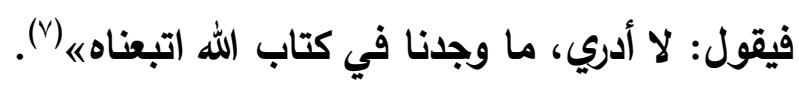

توا قصرت اتر عنه عقولهم، وحق لها أن تقصر عنه وتحسر دونه، فهنالك

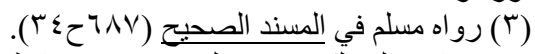

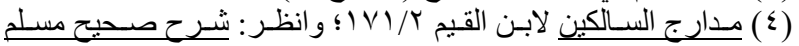

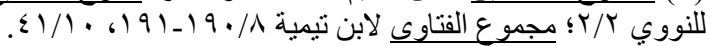

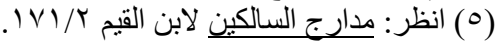

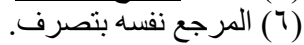

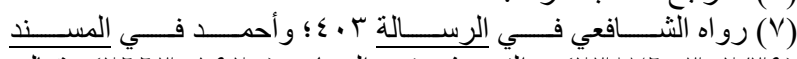
( )
التعنت والاعتراض (') وقد "أشار إلىى أن في الاشـتغال بامتثال أمـره واجتتـاب نهيـهـ شـغلاً عـن المسـائل ... فالـني يتعـين على المسـلم الاعتــاء بـه والاهتمـام أن يبحـث عمـا جـاء عن الله

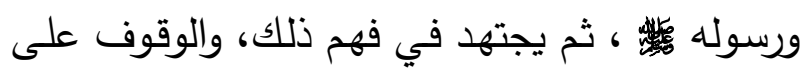
معانيـه، ثـم يثــتغل بالتصــيق بـذلك إن كـان مـن

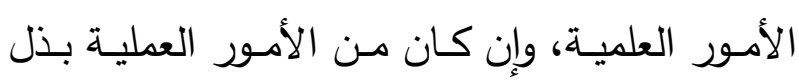
وسعه في الاجتهاد في فعل ما يستطيعه من الأوامر، واجتناب ما ينهى عنه، وتكون همته مصروفة بالكلية إلى ذلك، لا إلى غيره، وهكذا كـان حسال أصـحاب النبي إنما يحمد إذا كان للعمل، لا للمراء والجدال.... وفي

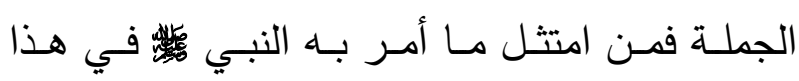
الحديث، وانتهى عما نهى عنه، وكان مشتغلاً بذلك عن غيره حصل لله النجاة في الدنيا والآخرة، ومن خالف ذلك واشتغل بخواطره وما يستحسنه وقع فيما حذر منه النبي بكثرة مسائلهم واختلافهم على أنبيائهم، وعدم انقيادهم وطاعتهم لرسلهم"(r).

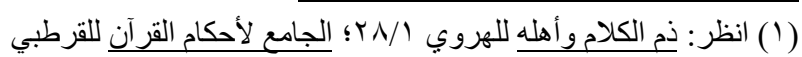

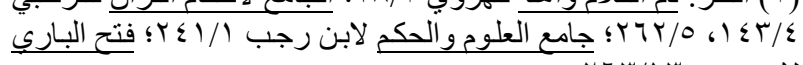

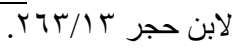

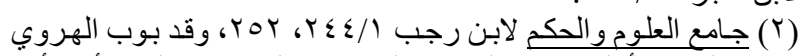

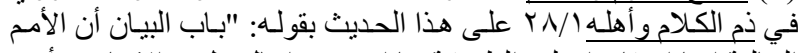

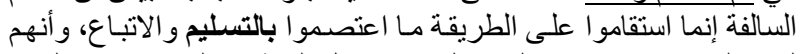

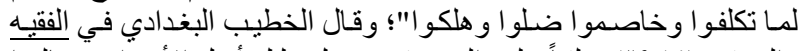

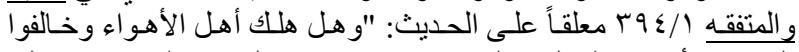

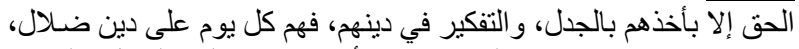

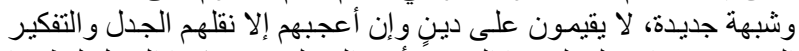

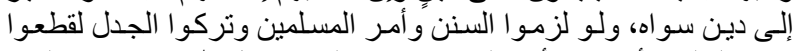

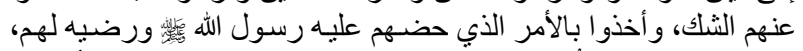
ولكنهم تكلفو ا ما قد كُفو ا مؤنته، وحملو العلى عقو لهم من النظر في أُمر الله $=$ 
وجـوب التسـليم لأمـر الله ورسـوله، وتشـديد تحـريم

الاعتراض عليهما، والتكبر عن طاعتهما(؟). والأحاديث في هذا المعنى كثيرة.

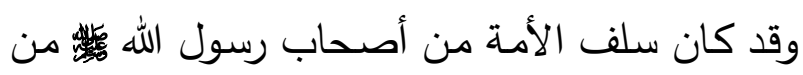

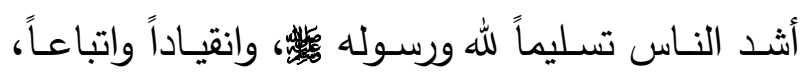

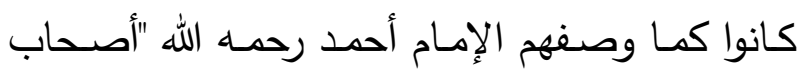

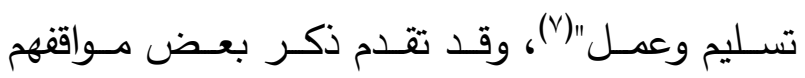
وتسليمهم، ومن ذلك أيضاً ما أخرجه البخاري ومسلم أن عمر بن الخطاب فئسيكان يقبل الحجر ويقول: "إني أعلم أنك حجر مـا تنفع ولا تضر ، ولولا أنسي رأيت رسول الله السنن في الكلام على هذا الأثر : "فيه من العلم أن

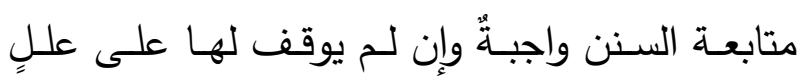

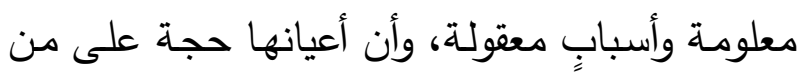

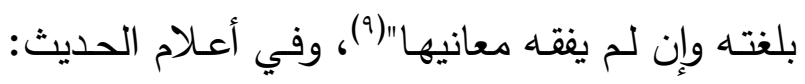

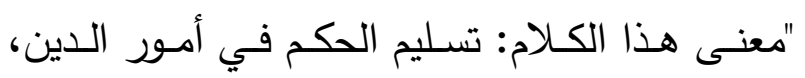

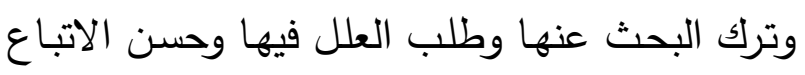
فيما لم يكثف لنا عنه من معانيها، وقد توجد أمور

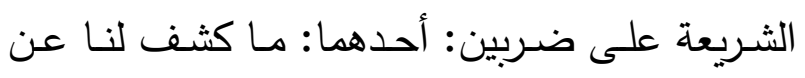
علته، وبين وجه الحكمة فيه، الآخر : ما لم يبين ذلك الك فيته

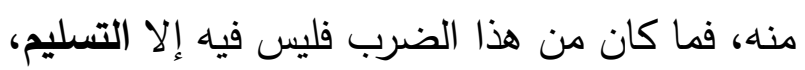
وترك المعارضة له بالقياس والمعقول"( ').

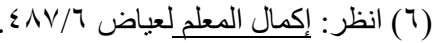

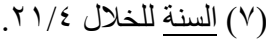

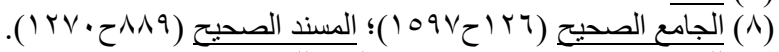

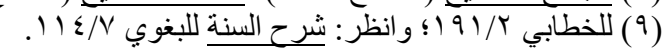

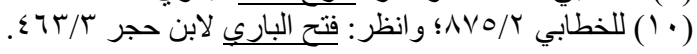

ووجها دلالة هذا الحديث ظاهرةٌ على وجوب التسليم

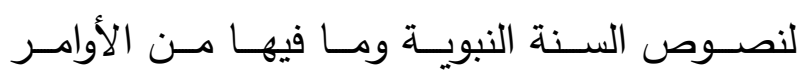
والنواهي، والإنكارِ على من لا يسلم لنصوص السنة، لنه ويشكك في حجيتها (').

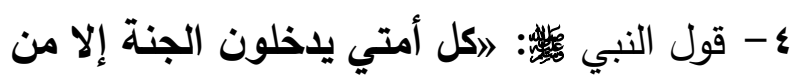

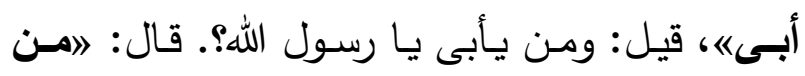

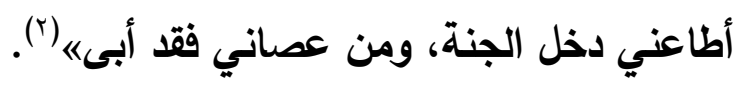

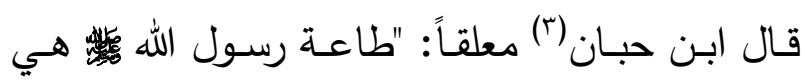

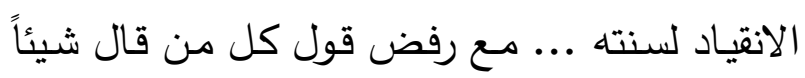
في دين الله جل وعلا بخـلاف سنته، دون الاحتيال

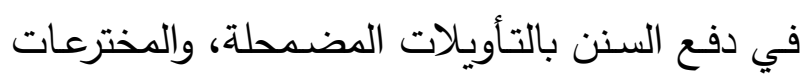

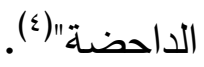

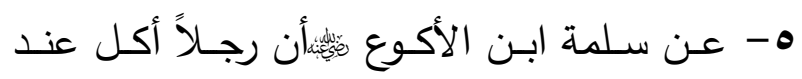

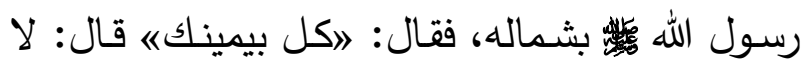

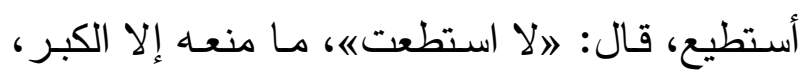
فما رفعها إلى فيه (0). فهذا الرجل الذي منعه الكبر من أن يسلِّم لأمر النبي 

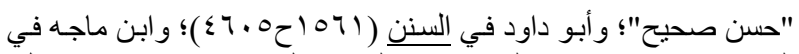

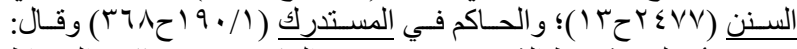

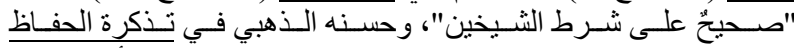

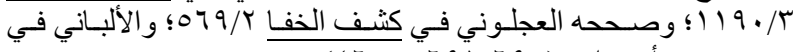

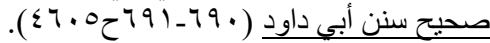

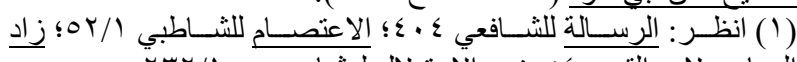

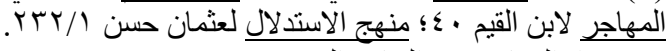

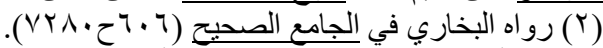

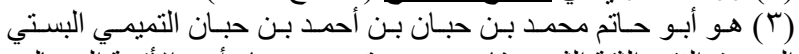

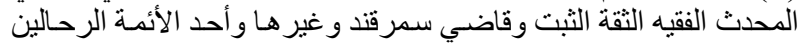

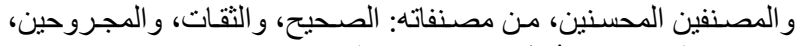

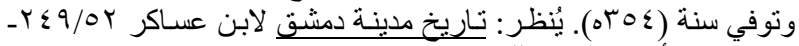

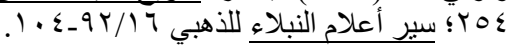

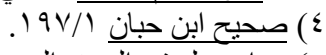

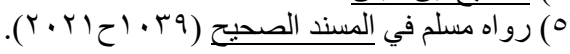


بناءً على مـا تقدم من نصوص الكتاب والسنة جعل أهل السنة والجماعة القرآن الكريم والسنـة النبويـة هما العمـدة فـي مصـادر تلقـي العقيـدة طلبـاً لسـلامتها واستقامتها، لا يقدمون عليهما قول قائل، ولا رأياً ولا هوى نفس، وبقية المصادر من فطرة وإجماع ومعقول مبنيـة على الكتاب والسـنة، وتابعـة لهــا، لا تتقدم عليهما، ولا تعارضهما. وهذه مجموعةٌ من نصوص علماء أهل السنة في هذا المعنى سوى ما تقدم ذكره: ا- قـال الزهــري رحمــهـ الله: "ســـلموا للســنة ولا

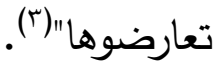

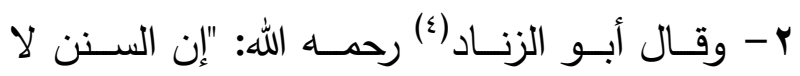
تخاصم، ولا ينبغي لها أن تتبع بالرأي والتفكير ، ولو فعل الناس ذلك لم يمض يوم إلا انتقلوا من دين إلى دين، ولكنـه ينبغي للسنن أن تلزم ويتمسك بها على ما وافق الرأي أو خالفه"(•).

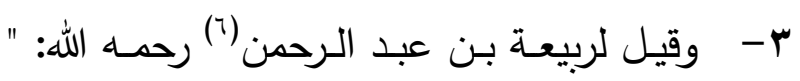
((الـرحمن على العـرش اسـتوى)(V) كيف استوى؟)
ولمـا كانت غزوة الأحزاب جاء الحارث الغطفاني (')

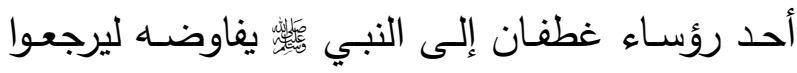
عن المدينة مقابل جزءٍ من تمرها، فقال: يا محمد: شـاطرنا تمـر المدينـة، قـال عليـهـ الصــلاة والســلام: 》حتى أستأمر السعود «، فبعث إلى رؤساء الأنصار منهم سعد بن معاذ وسعد بن عبادة رضـي الله عنهما فقال: »إني قد علمت أن العرب قد رمتكم عن قوسٍ واحــدةٍ وإن الحــارث يســألكم أن تشـــاطروه تمــر المدينة، فإن أردتم أن تدفعوا إليه عامكم هذا حتى تنظروا في أمـركم بعده، قالوا: يا رسول الله: أوحيّ من السـاء فالتسـليم لأمـر الله، أو عن رأيك وهواك فرأينا تبـع لهواك ورأيك، فإن كنت إنما تريد الإبقاء علينا، فوالله لقد رأيتنا وإياهم على سواءٍ ما ينالون منا

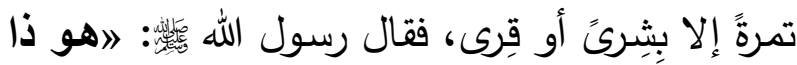
تسمعون ما يقولونه (r). والأخبار عن الصحابة هيّهَ: في هذا الباب أكثر من أن تحصى في مثل هذا البحث. جملةٌ من نصوص علماء أهل السنة والجماعة في في مئ وجوب التسليم لنصوص الكتاب والسنة

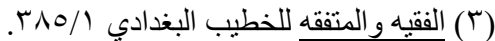

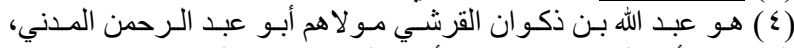

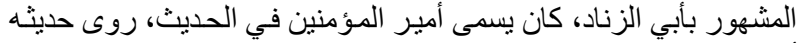

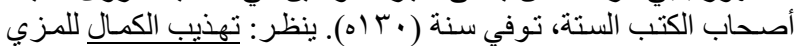

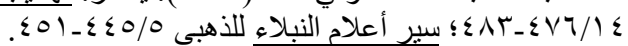

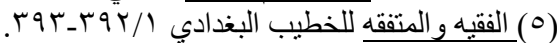

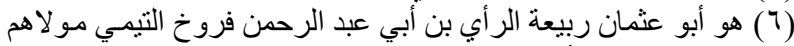

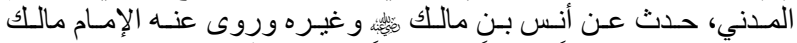

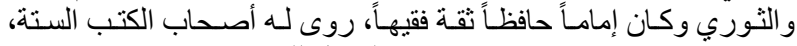

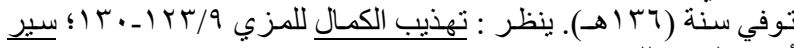

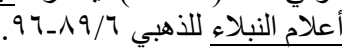

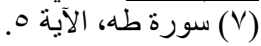

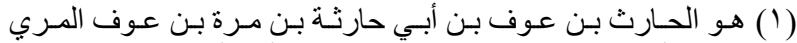

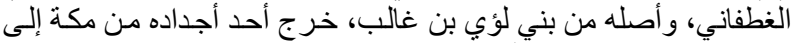

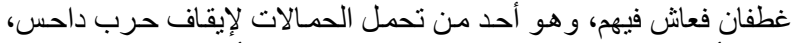

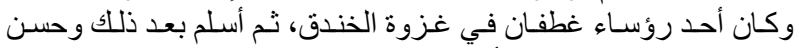

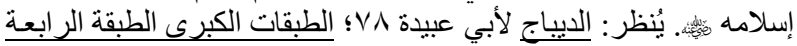

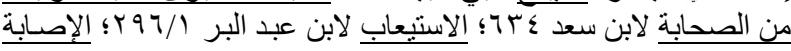

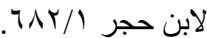

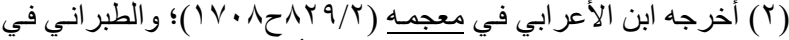

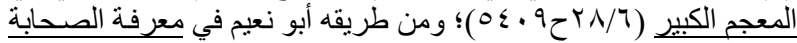

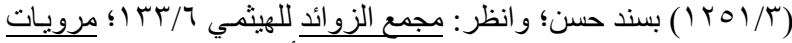

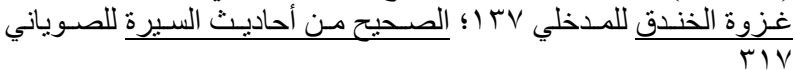


- - وكتب رجلٌ إلى الإمـام أحمد رحمـه الله يسأله عن مناظرة أهل الكلام والجلوس معهم فقال: "الذي كنا نسمع وأدركنا عليه من أدركنا من سلفنا من أهل العلم أنهم كـانوا يكرهـون الكـلام والخـوض مـع أهـل الزيخ، وإنما الأمر في التسليم والانتهاء إلى ما في

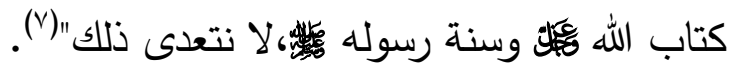

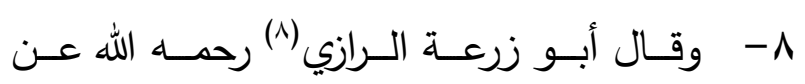
نصـوص الصـفات: "المعتقد مـن هذه الأخبـار مـراد

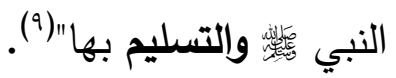

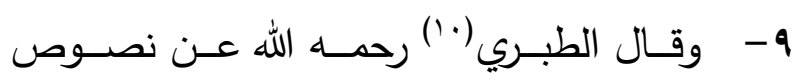
الصـفات: "ليس عندنا للخبـر إلا التسـليم والإيمـان به" (11) • 1 - وقـال ابـن خزيمـة(ז') رحمـه الله: "إن الأخبـار في صفات الله موافقةٌ لكتاب الله تعالى، نقلها الخلف الف الف اله عـن الســف، قرنـاً بعـد قـرنٍ، مـن لـدن الصـحابة

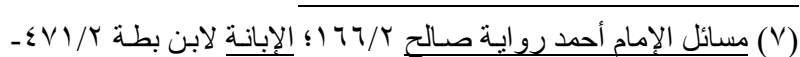
أح أحمد أin

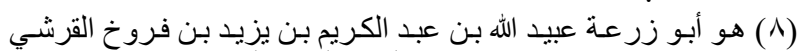

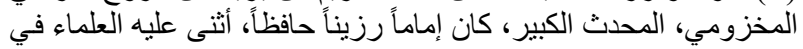

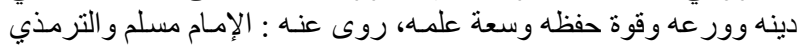

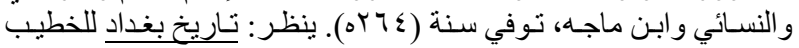

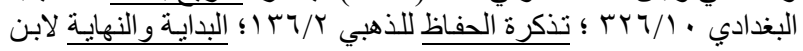

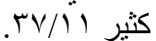

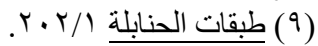

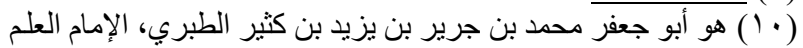

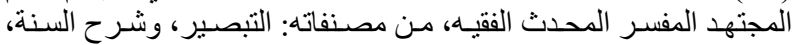

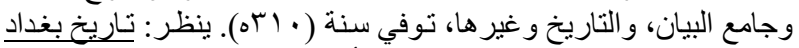

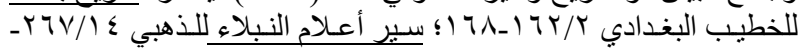

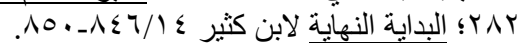

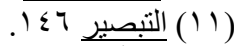

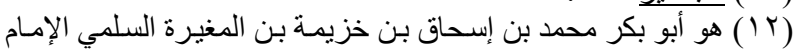

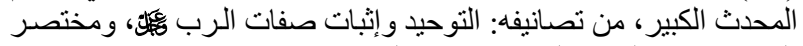

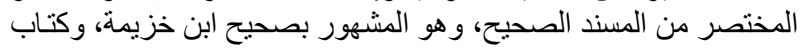

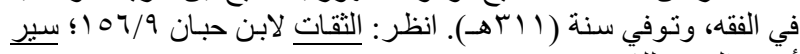

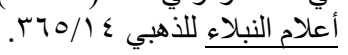

قـال: الاسـتواء منــه غيـر معقـول، وعلينـا وعليـك

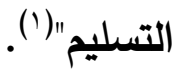
ع - ـ وقـال الأوزاعـي (؟) رحمــهـ الله: "مـن الله تعـالى التتزيل، وعلى رسوله التبليخ، وعلينا التسليم"("). ه- وقال الإمـام الشـافعي رحمـه الله: "أبـان الله لنـا

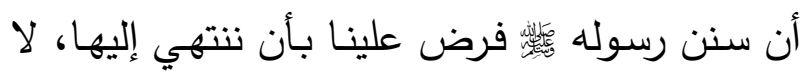
أن لنـا معهــا مـن الأمـر شــيء إلا التســليم لهــا واتباعها، ولا أنها تعرض على قياس ولا على شيء غيرها، وأن كل ما سواها من قول الآدميين تبع لها، فذكَّرتُ ما قلت من هذا العددَ من أهل العلم بالقرآن والسـنن والآثـار واختـلاف النـاس والقيـاس والمعقول فكلهم قـال: هذا مـذهبنا ومـذهب جميع مـن رضـينا ممن لقينا، وحكي لنا عنه من أهل العلم"(£). צ- وقال علي ابن المديني(ن) رحمه الله: "الإيمان والتصديق بالشفاعة، وبأقوام يخرجون من النار بعدما احترقوا وصـاروا فحماً كما جاء الأثر والتصديق بـه

والتسليم" (†).

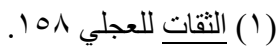

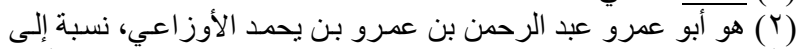

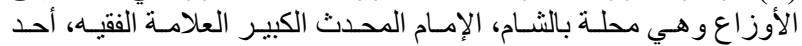

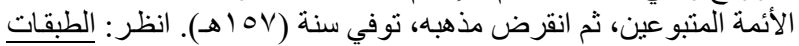

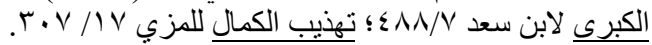

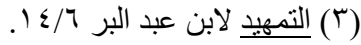

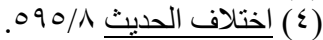

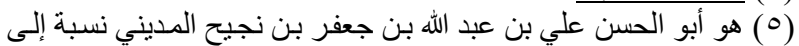

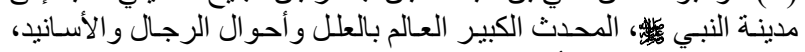

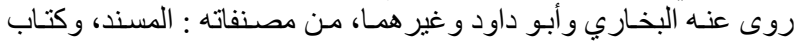

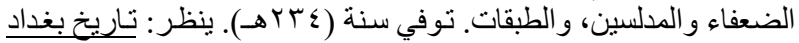

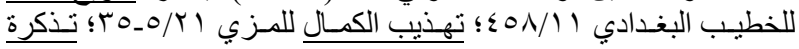

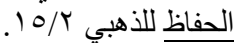

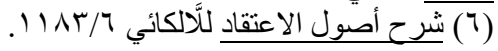


رسوله العلماء ممن اتبع ولم يبتدع، ولا يقال فيه: كيف؟ بل التسليم له" (V). ع ا - وقال ابن أبي زيد القيرواني(^) رحمه الله: "باب ذكر السنن التي خلافها البدع وذكر الاقتداء والاتباع ... والتســليم للســن، لا تعـارض بـرأي، ولا تـدافع بقياس، ومـا تأوله منها السلف الصـالح تأولنـاه، ومـا عملوا به عملناه، وما تركوه تركناه، ويسعنا أن نمسك عما أمسكوا، ونتبعهم فيمـا بينوا ... وكل مـا قدمنا ذكـره فهـو قـول أهـل السـنة وأئهــة النـاس في الفقــــ والحـديث على مـا بينـاه، وكلـهـه قـول مالـك، فمنــهـ منصوص من قوله، ومنه معلوم من مذهبه"(9). ه 1 - وقـال ابـن بطـة رحمـه الله: "اعلمـوا رحمكم الله أن مـن صـفات المـؤمنين مـن أهـل الحـق تصــديقَ الآثار الصحيحة، وتلقيها بالقبول، وترك الاعتراض عليها بالقياس ومواضعة القول بالآراء والأهواء، فإن الإيمان تصديق، والمؤمن هو المصدق، قال الله هَّلَّ: (فـلا وربك لا يؤمنـون حتـى يحكمـوك فيمـا شــر بينهم ثم لا يجدوا في أنفسهم حرجًا ممـا قضيت

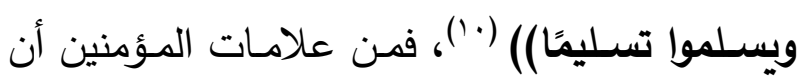
يصفوا الله بما وصف به نفسه، وبما وصفه به رسوله

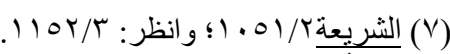

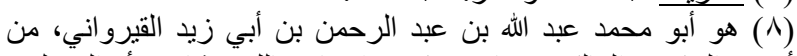

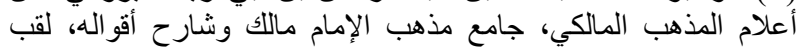

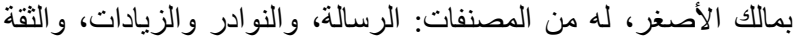

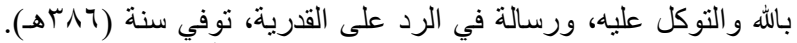

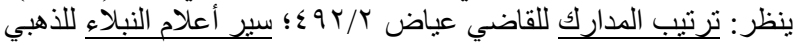

$.1 V_{-1} 1 . / 1 V$

.11V ، 19) (1) (1) سورة النساء، الآية، (1)
والتابعين إلى عصرنا هذا، على سبيل الصفات لله

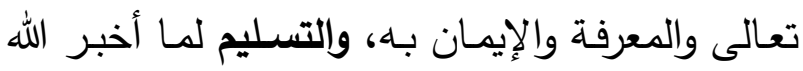

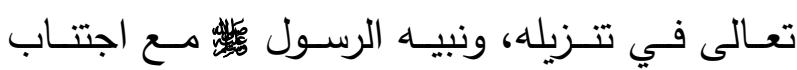

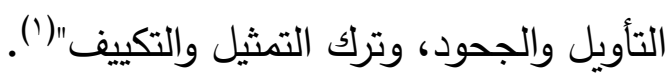

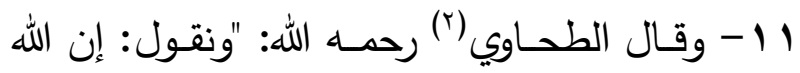
اتخذ إبراهيم خليلاً، وكلم الله موسىى تكليماً، إيمانـاً

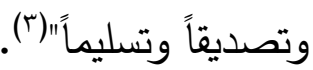
r أ - وقـال البربهاري(£) رحمـه الله: "اعلم رحمك الله

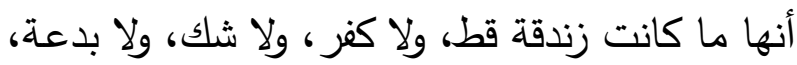
ولا ضــلالة، ولا حيــرة فـي الــين إلا مــن الكــلام وأصــاب الكـلام والجــل والمــراء والخصــومة ـ... فعليك بالتسليم والرضى بالآثار وأهل الآثار ، والكف واه والبه

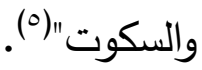
ب ا - وقـال الآجري(؟) رحمـهـ الله: "اعلمـوا وفقتـا الله وإياكم للرشاد من القول والعمل أن أهل الحق يصفون

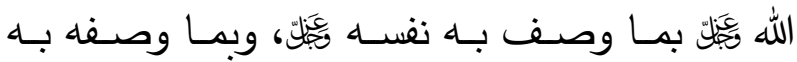

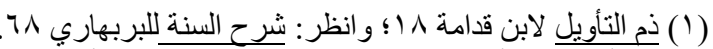

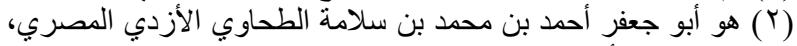

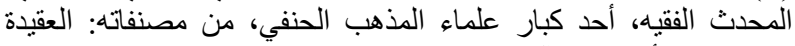

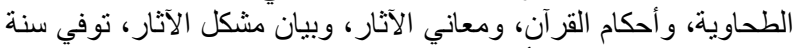

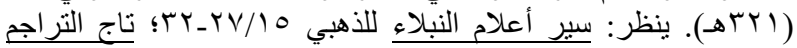

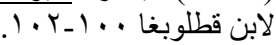

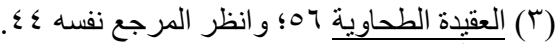

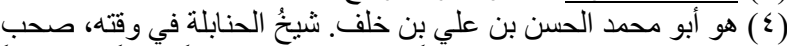

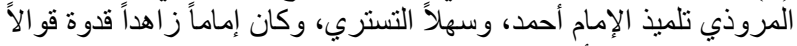

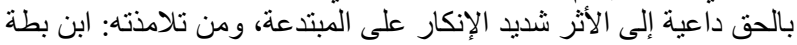

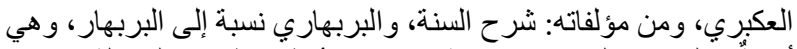

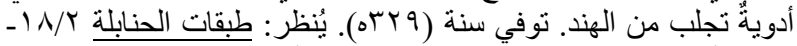

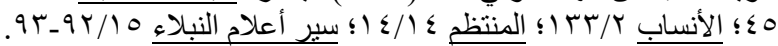

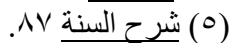

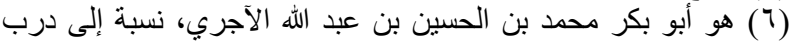

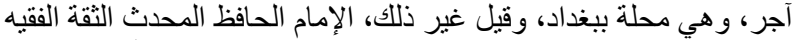

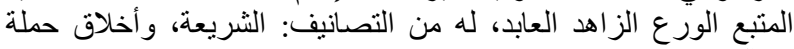

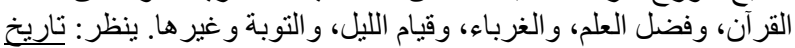

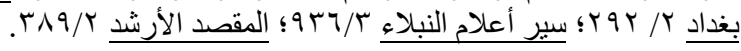




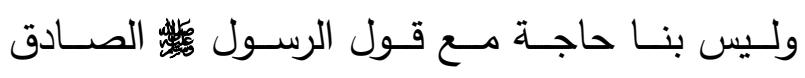

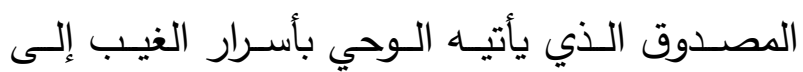

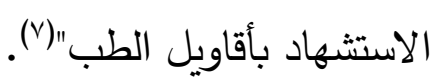

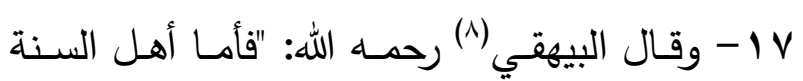

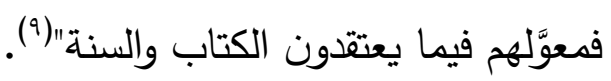

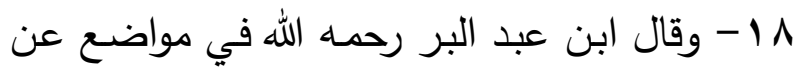

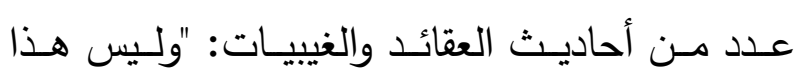
موضع نظر ولا قياس؛ لأن القياس إنما يكون فيما

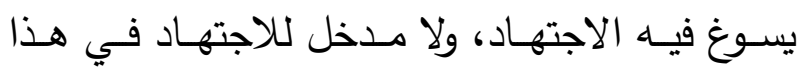

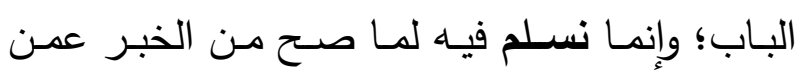
يجب التسليم له"(·) "وهذه أشياء لا تدرك بعقل، ولا لان

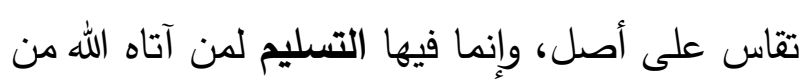

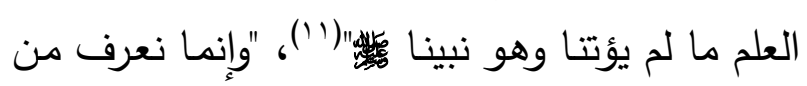

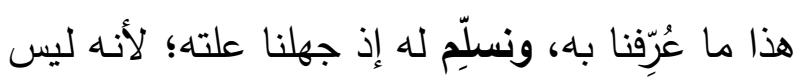

برأي ولكنه قول من يجب التسليم له له

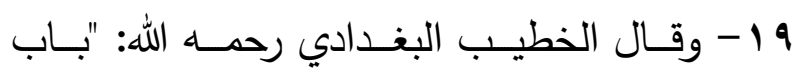
تعظيم السنن والحث على التمسك بها والتسليم لها والانقياد إليها وترك الاعتراض عليها"(r").

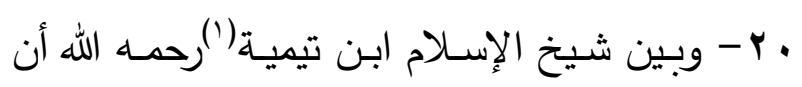

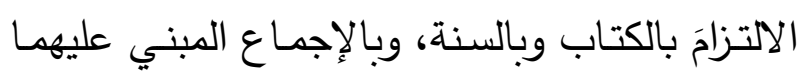

أعلام الحديث س/r) (r) (^)

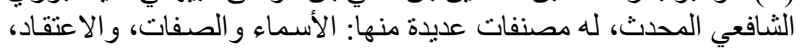

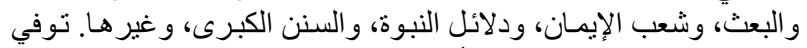

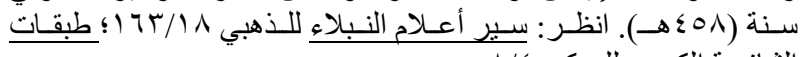

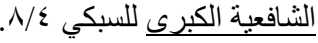

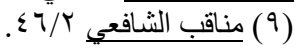

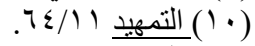

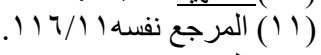

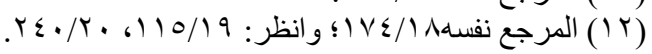

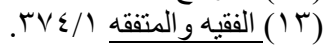

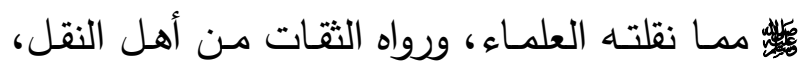

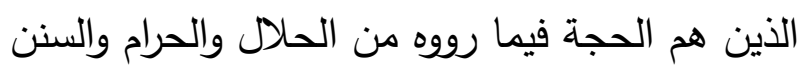

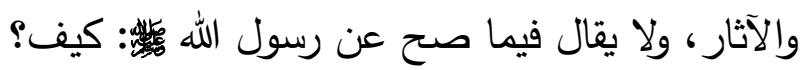

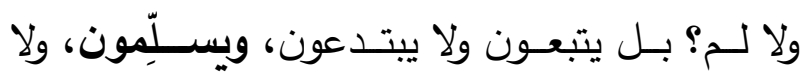
يعارضون، ويتيقنون ولا يشكون ولا يرتابون" ('). 17 وثبـت عن رسـول الله وقال في شرحه لبعض الأحاديث الثابتة التي يردها العقلانيون بعقولهم(؛): "وليس في هذا إلا التصديق الاحيق

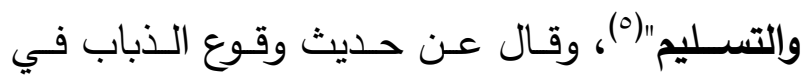

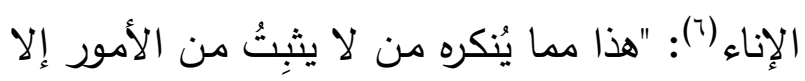

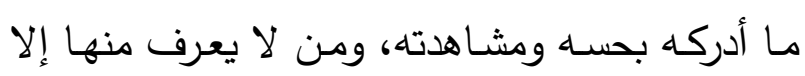

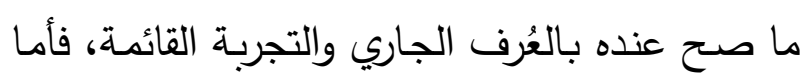

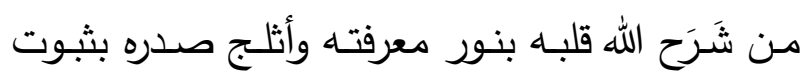
نبـوة رسـوله

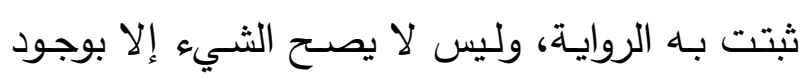

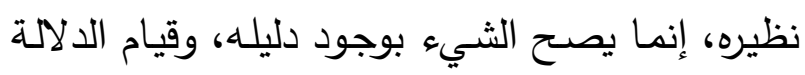

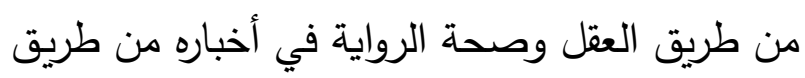

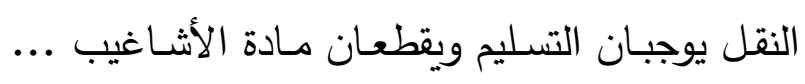

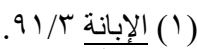
(Y) (T) الإبانة سليمان حمد بن محمد بن إبر اهيم بن الخطاب البستي الخطابي

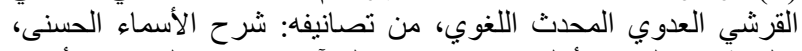

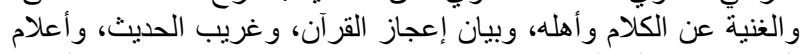

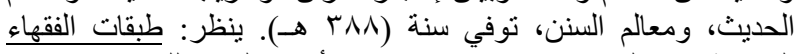

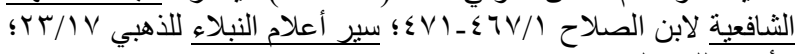

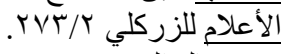

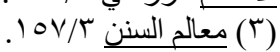

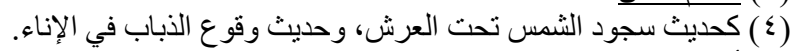

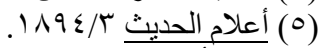

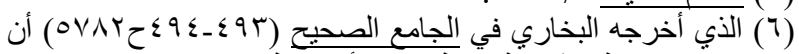

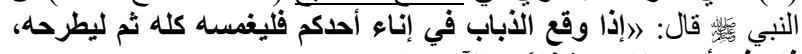
فإن في أحد جناحيه شفاءً، والآخر داءع). 
حصـول التصـديق بجميـع نصـوص الكتاب والسنة؛ إذ التسليم دليل على ذلك، فضـلاً عن دلالته على تعظيم العبد للنصوص الشرعية، واستغنائه بها عما سواها.

حصــول اليقـين والثبـات لِلمُسَـلِّم، ووضـوح معتقده، فالتسليم للنصوص يغرس العقيدة في نفوس المُسَلِّمين بالأسـلوب المناسـب ممـا يـورث توافقاً بين الفطرة السليمة والعقل الصحيح. حصول الوسطية في المنهج بين من فرط وأفرط في شتى مسائل الاعتقاد. بلوغ الهداية والنجاة والاستقامة والعزة والفلاح في الدنيا والآخرة، فإنـه "بحسب متابعـة الرسـول تكون العزة والكفاية والنصرة، كما أن بحسب متابعته تكـون الهدايـة والفـلاح والنجـاة، فـالله سـبحانه علـق سـعادة الـارين بمتابعتـه، وجعـل شـقاوة الـدارين في مخالفتـه، فلأتباعــه الهـدى والأمـن والفــلاح والعـزة والكفايـة والنصـرة والولايـة والتأييد وطيـب العيش في الـدنيا والآخـرة، ولمخالفيـه الذلـة والصــار والخـوف والضلال والخذلان والثقاء في الدنيا والآخرة"(๕). وإنما كان التسليم لنصـوص الكتاب والسنة موصـلاً إلـى اسـتقامة العقيـدة وعصــتها مـن الضــلالة لأن نصوص الكتاب والسنة في عرضها للعقيدة وتقريرها لها قد بلغت الغاية في الصدق وتحقق القطعية فيما تتاولته من مسائل، وبالتالي العصمة من أي خطأ أو ضـالل، فهـي عقيـدة يقينيـة لا تقبـل أي تشكيك أو
هو الفيصـلُ بين أهل السـنة والجماعـة وغيرهم من أهل البدع فقال: "فمن قال بالكتاب والسنة والإجماع فهو من أهل السنـة والجماعـة"(r)، وقال في موضٍٍِ آخر : "فيأخذ المسلمون جميع دينهم من الاعتقادات والعبادات وغير ذلك من كتاب الله وسنة رسوله وما اتفق عليه سلف الأمة وأئمتها، وليس ذلك مخالفاً للعقل الصـريح؛ فـإن مـا خـالف العقل الصـريح فهو باطل، وليس في الكتاب والسـنة والإجمـاع باطل، ولكـن فيــه ألفـاظ قـــ لا يفهمهـا بعـض النـاس، أو

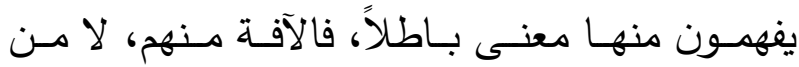

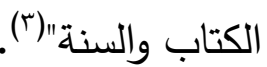
وهذا الذي ذكرتهـ إن هو إلا غيضُ مـن فيض مـن كلام علماء المسلمين وأئمتهم، ولا يحتمل هذا البحث أكثر من هذا. المطلب الثاني: أثر التسليم للنصوص الثرعية في

\section{استقامة العقيدة}

للتسليم للنصوص الشرعية آثار جليلةٌ ونتائج عظيمة تتحقق بمقدار ما يتحقق من ذلك التسليم، ومن تلك

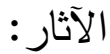

تحقيق معنى الإيمان بالله ورسـالاته؛ إذ إن متابعة الرسول كئد شرطٌ في تحصيل الإيمان.

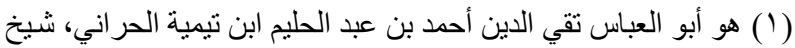

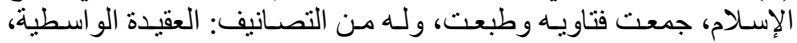

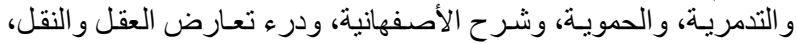

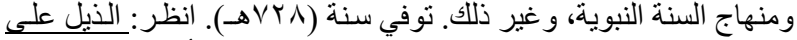

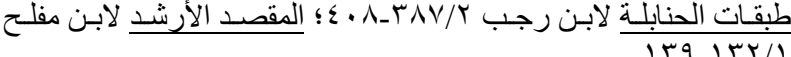


وإنما كان التسليم لنصوص الكتاب والسنة شرطاً في استقامة العقيدة من جهة أن أمور العقيدة التي يجب

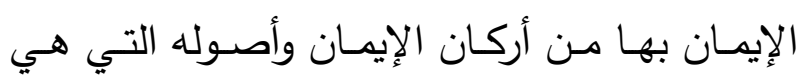
مدار العقيدة إنمـا هي غيـب، ولا تتحقق العقيدة إلا بالتسليم بتلك الأصـول؛ لأن الإنسـان لا يستطيع أن

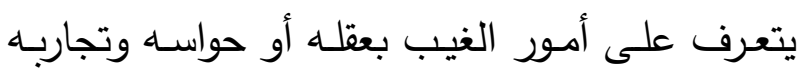

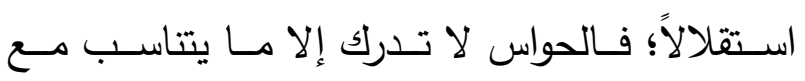
حـدودها مـن المحسوسـات، والعقـل البشـري محـدود وقاصر ؛ ولذلك وجب أن يكون المصدر الذي يتعرف بـه العقل على أمسور الغيـب، ويستقي منــه مسـائل

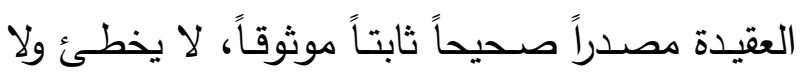
ينحرف، وليس ذلك إلا في الوحي من القرآن العظيم

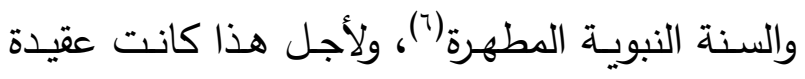
أهل السنـة والجماعـة توقيفيـةً تقوم على التسليم بمـا

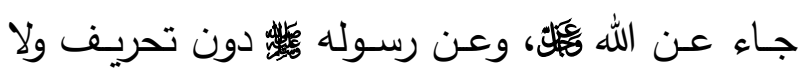
تأويل (v) وسيكون الحديث في هذا المبحث عن بعض صور استقامة العقيدة كأثرٍ للتسليم للنصوص الشرعية وأدلة ذلك.

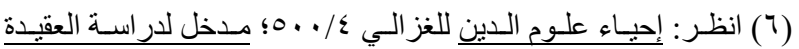

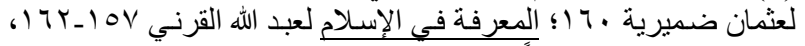

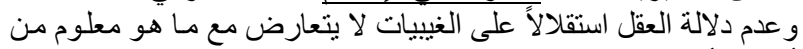

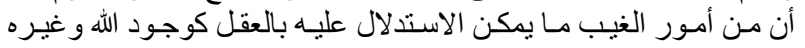

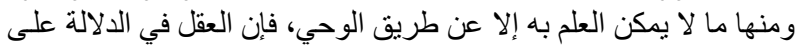

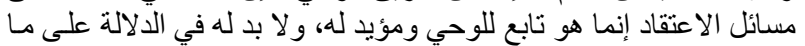

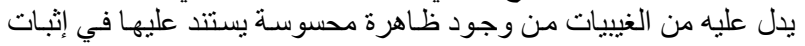

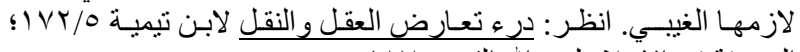

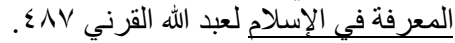

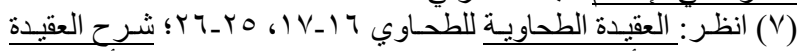

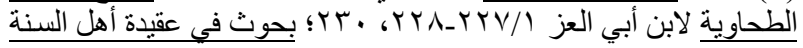

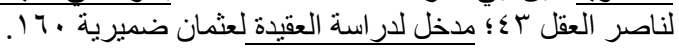

اعتراض؛ فلذلك نتج عن التسليم والانقياد لها ذلك

الأثر البالغ في استقامة عقيدة من سلم لهاب(')

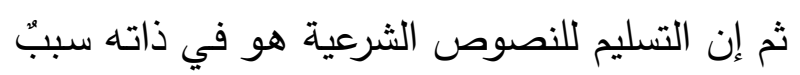

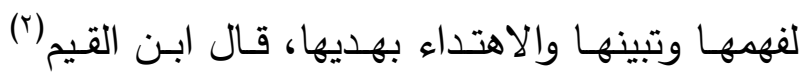

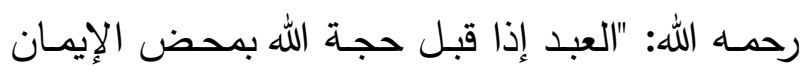
والتسليم والانقياد كان هذا القبول هو سبب تبينها وظهورها وانكثافها لقلبه"("). وليس التسليم للنصوص الثرعية مؤثراً في استقامة

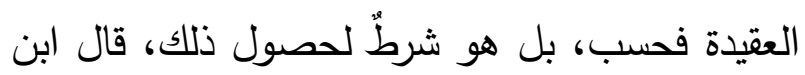

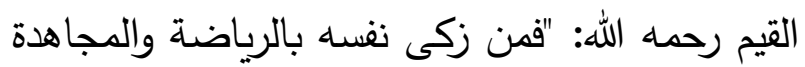

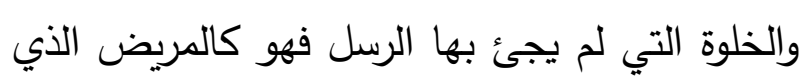
يعالج نفسه برأيه، وأين يقع رأيه من معرفة الطبيب؟، أنسئ

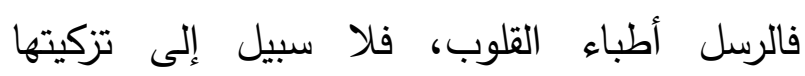

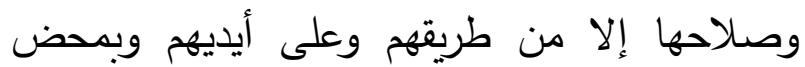

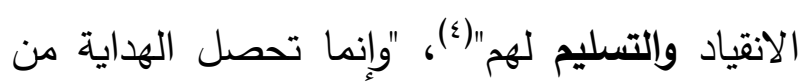
ألفاظ رسول الله

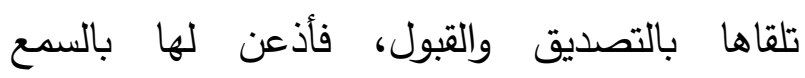
والطاعة، وقابلها بالرضى والتسليم، وعلم أنها منبع

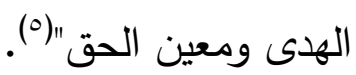

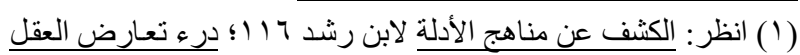

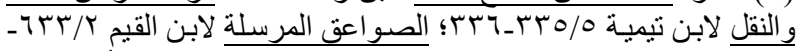

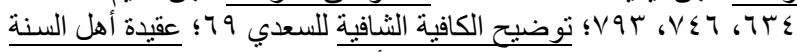

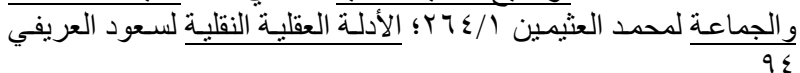

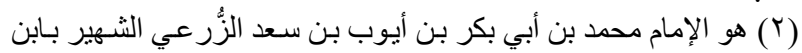

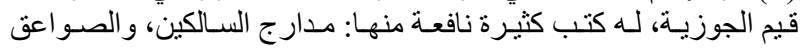

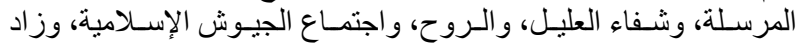

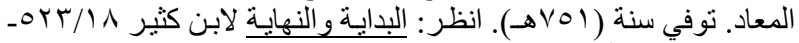

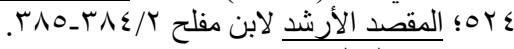
(ك) (r) مدارج السالكين

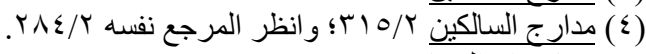
r 
من الإيمان والدين، قال الله تعالى: ((فإن آمنوا بمثل

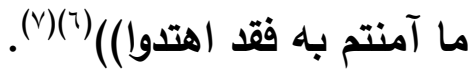
نهـى الله تعـالى المؤمنين عـن طاعـة أهـل

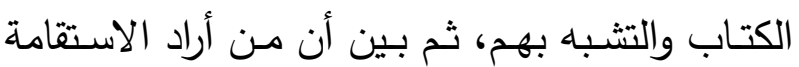
والهداية إلى الطريق المستقيم الموصل إلى رضوانه

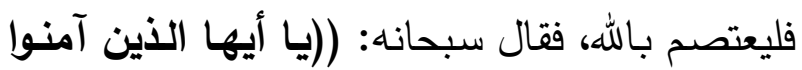
إن تطيعوا فريقًا من الذين أوتوا الكتاب يردوكم بعد بالئ

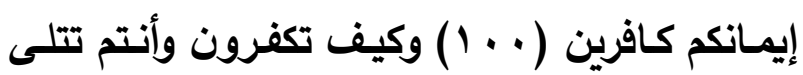
عليكم آيات الله وفيكم رسوله ومن يعتصم بالله فقد

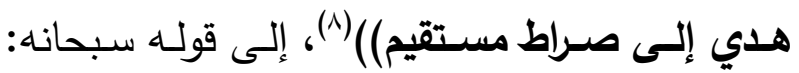

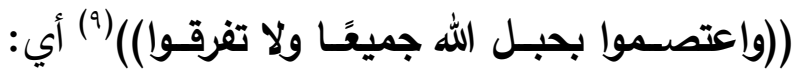
"وتمسكوا بدين الله الذي أمركم به، وعهده الذي عهده

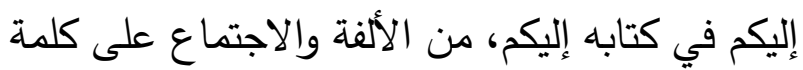

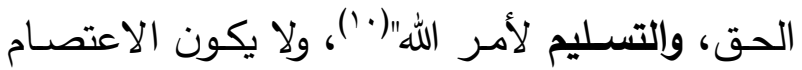

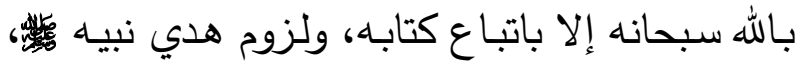
ف"من يتعلق بأسباب الله، ويتمسك بدينه وطاعته فقد

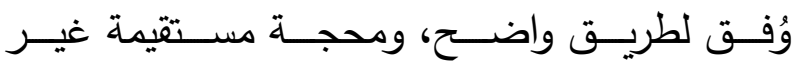

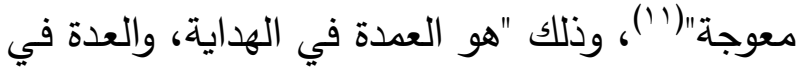
مباعدة الغواية، والوسيلة إلى الرشاد، وطريق السداد،

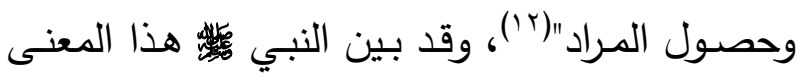

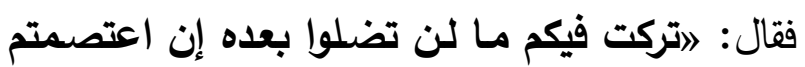

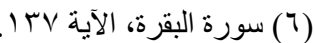

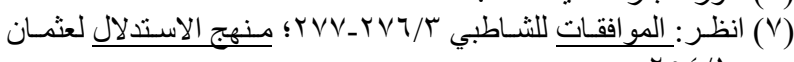

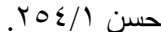

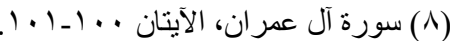

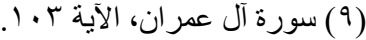

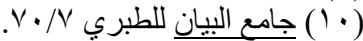

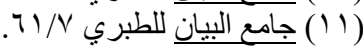

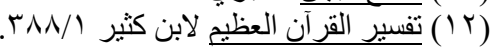

1- تحقيق الهداية للمسلِّم للنصوص الثرعية: للتسليم للنصوص الشرعية أثرُ عظيمٌ في بلوغ الهداية والاستقامة، والنجاة من الضـلالة والغواية؛ إذ الهداية

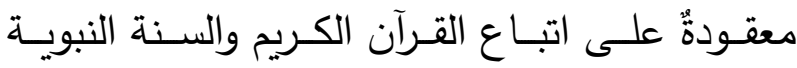

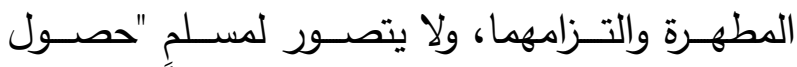

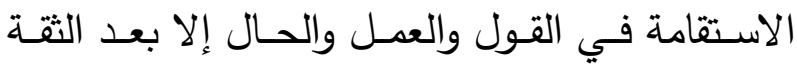

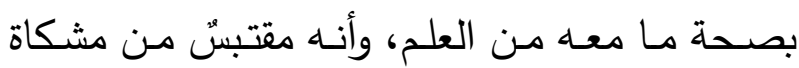

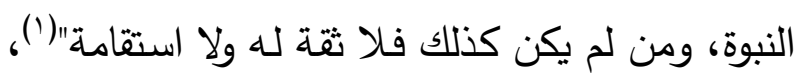

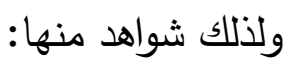
قول الله سبحانه وتعالى: ((فإما يأتينكم مني

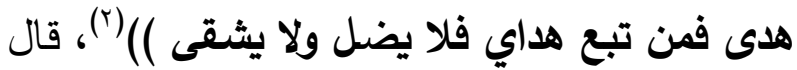

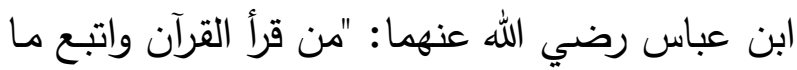
فيه هداه الله من الضـلالة في الدنيا، ووقاه يوم القيامسة سوء الحساب وذلك بأن الله كئليَ قال: ((فإمـا يأتينكم

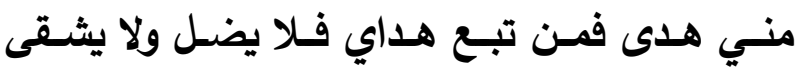

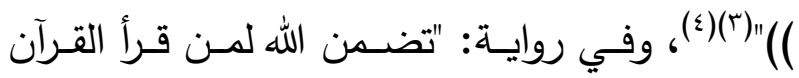

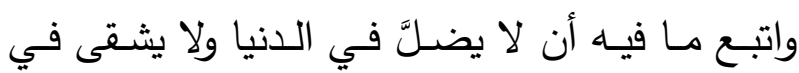
الآخرة"، ثم تلا هذه الآية (ه). قصـر القـرآن الكريم الهدايـة على الانقيــاد والالتزام بمـا كـان عليـه رسول الله

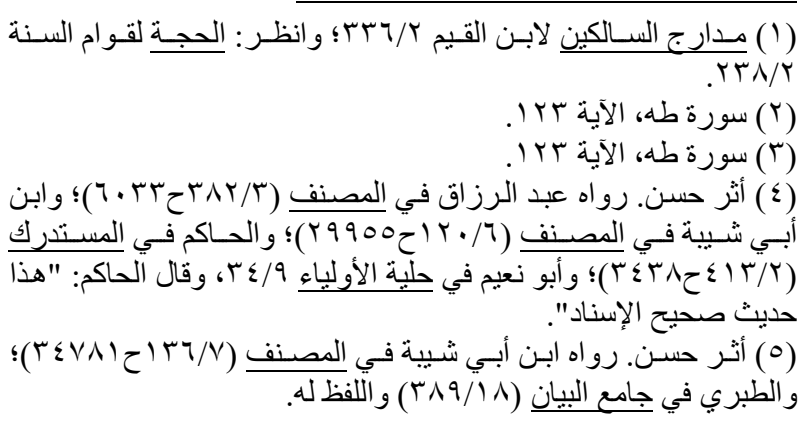


ومتشابهه،((وهب)) يا ربنا ((من لدنك رحمة))ر ...

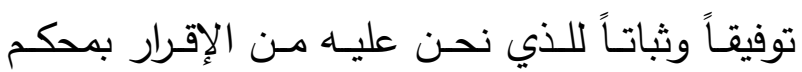
كتابك ومتشابهاه، ((إنك أنت الوهاب)() (^) يعني: إنكانكان أنت المعطي عبادك التوفيق والسـداد للثبات على التى دينك، وتصديق كتابك ورسلك" (9). وإن من أصرح الأدلة الدالة على أن طريقَ ولتيق استقامة الاعتقاد هو التمسك بالقرآن العظيم والسنة المطهـرة والتسـليم لهـــا قـولَ الله تعـالى عـن القـرآن الكريم: ((إن هو إلا ذكر للعالمين (rV) لمن شـاء

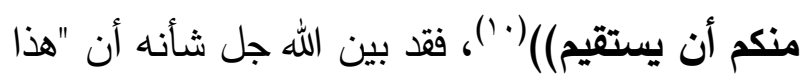

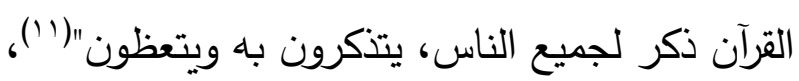

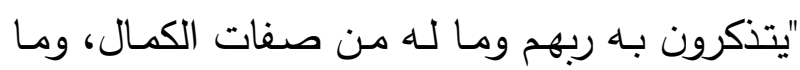
ينزه عنه من النقائص والرذائل والأمثال، ويتذكرون بـه الأوامر والنواهي وحكمها، ويتذكرون بـه الأحكام

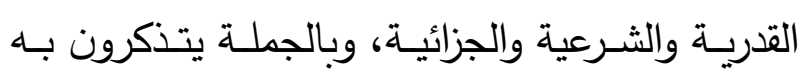

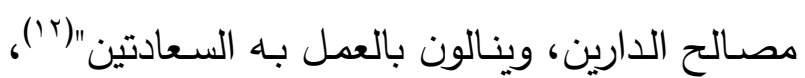

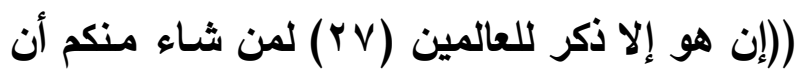

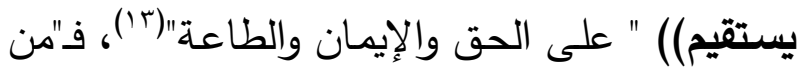
أراد الهداية فعليه بهذا القرآن، فإنه منجاة لله وهداية، ولا هداية فيما سواه"(؛) (1).

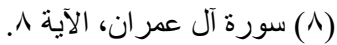

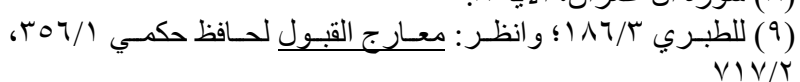

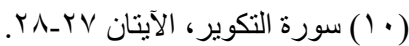

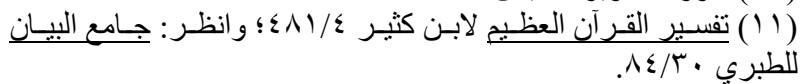

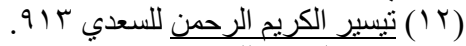

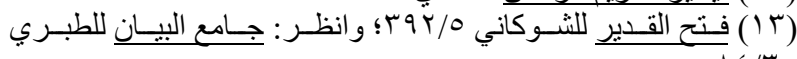
$\Lambda \varepsilon / r$.

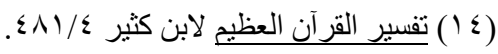

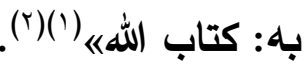
لما بين الله تعالى تسليم الراسخين في العلم لآيات الكتاب، وأنهم يقولون عن المحكم والمتشابه:

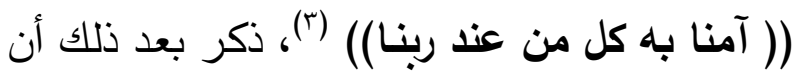

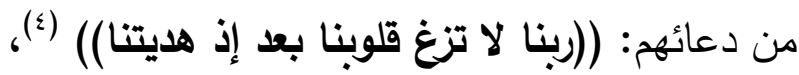

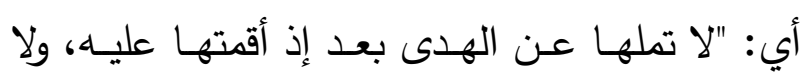
تجعلنا كالذين في قلوبهم زيغٌ الذين يتبعون ما تشابه

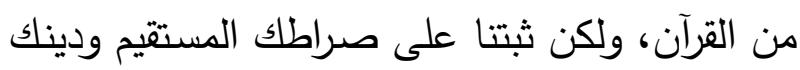
القويم"(0)، جـاء في جـامع البيـان في تفئسير الآيـة الكريمة والتي قبلها: "قوله تعالى: ((ربنا لا تزغ قلوبنا

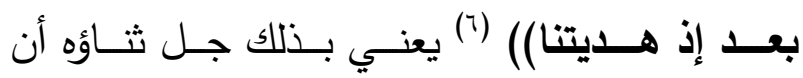

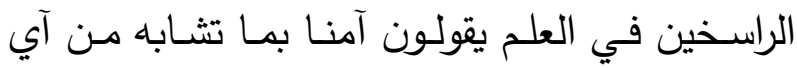
كتاب الله وأنه والمحكم من آيه من تنزيل ربنا ووحيه، ويقولون أيضاً: ((ربنا لا تزغ قلوبنا بعد إذ هديتنا))

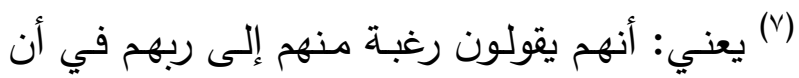

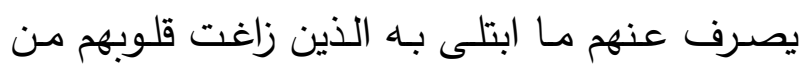

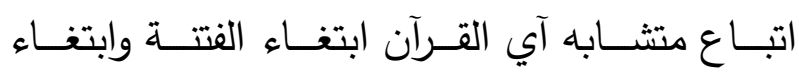

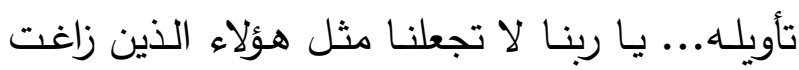

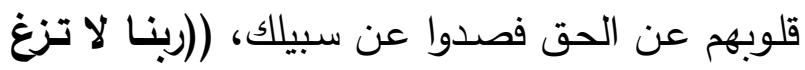

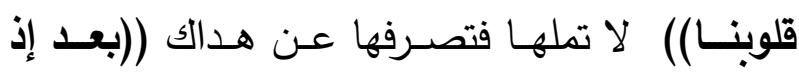

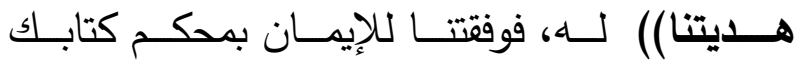

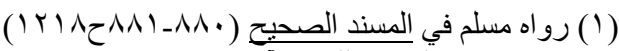

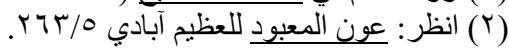

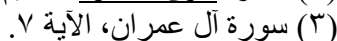

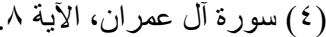

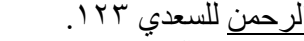

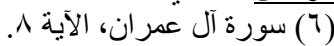

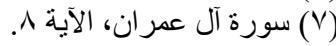

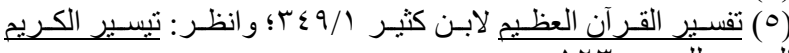


أفحكم الجاهليـة يبغون ومـن أحسن مـن الله حكمـاً لقوم يوقنون) (·) (') "فأخبر سبحانه وتعالى أنـه ليس وراء ما أنزله إلا اتباع الهوى الذي يضل عن سبيله، ولـيس وراء حكمـه إلا حكـم الجاهليـة، وكـل الآراء

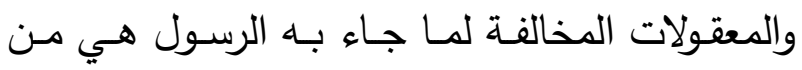
قضـايا الهـوى وأحكـام الجاهليـة وإن ســاها أربابهـا بـالقواطع العقليـة والبـراهين اليقينيـة، فهـي كتسـمية المشركين أوثانهم وأصنامهم آلهة، وتسمية المنافقين السعيَ في الأرض بالفساد وصدَّ القلوب عن الإيمان إصلاحاً وإحساناً وتوفيقاً"(') قـال السـعدي رحمـه الله في تقسـير قولـه تعـالى (ولقد آتينا موسى الكتاب فـاختلف فيـه ولولا كلمـة سبقت من ربك لقضـي بينهم وإنهم لفي شكك منـه مريـب ( · 11 ) وإن كـلا لمـا ليوفينهم ربك أعمـالهم إنـا بمـا يعملـون خبيـر (1 111$)$ ومــن تــاب معــك ولا تطغـوا إنـــه بمــا تعملــون بصسير)('ا'): "يخبر تعـالى أنـه آتى موسـى الكتاب، الذي هو التوراة، الموجب للاتفاق على أوامره ونواهيه والاجتماع، ولكن مع هذا، فإن المنتسبين إليه اختلفوا

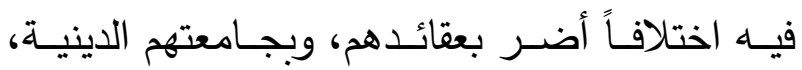

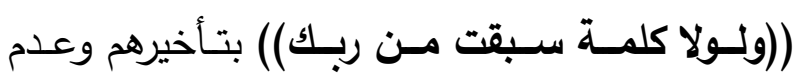
معاجلتهم بالعذاب ((لقضسي بينهم)) بإحلال العقوبة بالظالم، ولكنه تعالى اقتضت حكمته أن أخر القضاء

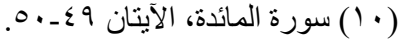

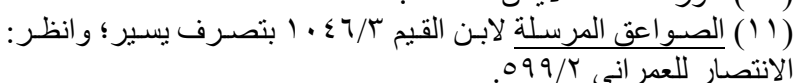

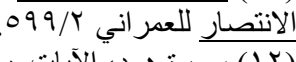

وقال الله جل اسمه لنبيه أمسرت ومـن تـاب معـك ولا تطغـوا)(') ')، وقـال لـه:

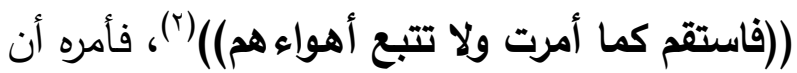
يستقيم ومن تاب معه ويثبتوا على الدين الذي أمرهم

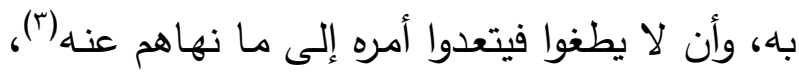
ومما نهاهم عنـه اتبـاع الأهواء المضلة، قال سفيان بـن عيينـة(أ) رحمـهـ الله في تفسير قـول الله تعـالى:

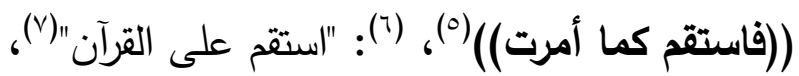
فهذه النصوص وأمثالها أوصى الله تعالى فيها باتباع ما أمر، وبين أن الاستقامة في ذلك(^)، ونهى عن اتباع الأهواء التي تضل عن الصراط المستقيم، وكلُّ

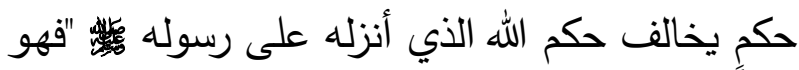
مـن أحكـام الهـوى، لا مـن أحكـام العقـل، وهـو مـن أحكام الجاهلية لا من حكم العلم والهدى"(9) كما قال تعـالى: ((وأن احكـم بيـنهم بمـا أنـزل الله ولا تتبـع أهواءهم واحذرهم أن يفتنوك عن بعض مـا أنزل الله إليـك فبإن تولــوا فـاعلم أنمــا يربــــ الله أن يصـيبهم ببعض ذنوبهم وإن كثيراً من الناس لفاسقون (9 \&)

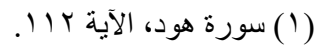

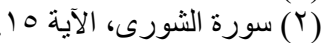

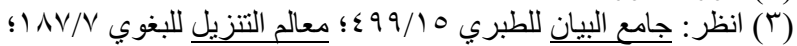

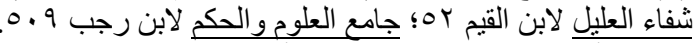

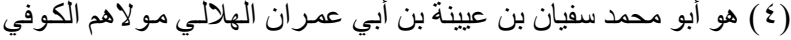

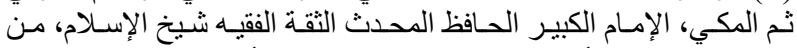

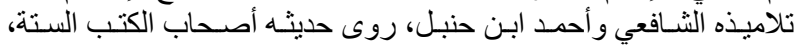

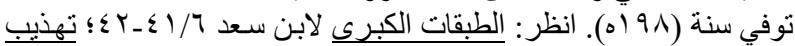

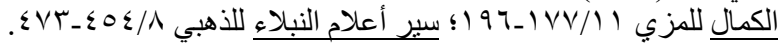

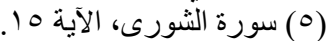

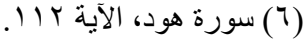

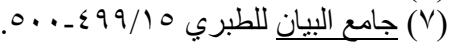

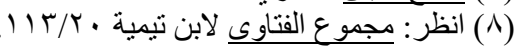

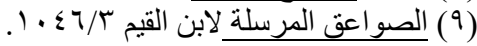


ولما افترق أهل البدع على طرفي نقيض بين الإفراط

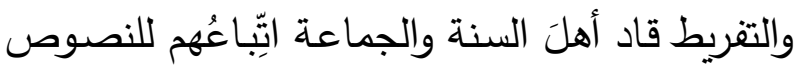

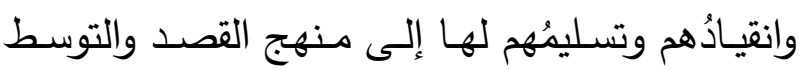

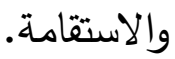

كتب عمر بن عبد العزيز رحمه الله إلى رجلٍ سأله عن القدر : "أُوصيك بتقوى اللَّهِ والاقتصـاد في أمره،

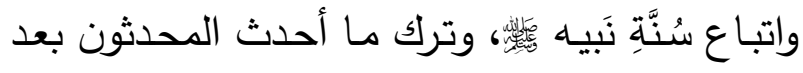
ما جرت بـه سنته، وكُفوا مؤنته، فعليك بلزوم السُّنَّةِ

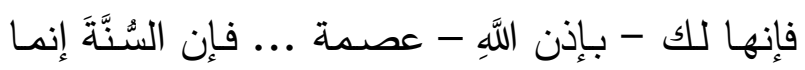

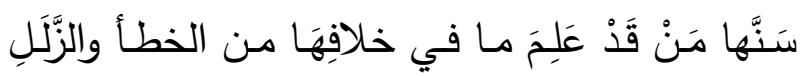

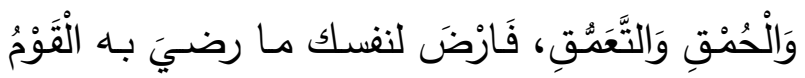

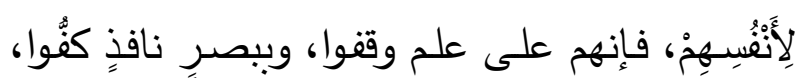
وهم على كثف الأمور كانوا أقوى، وبفضلِ مانِ ما كَانُوا فيه أَوْلَّى، فإن كان الهدى ما كأنتم عليه لقد سبقتموهم

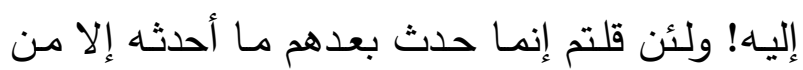

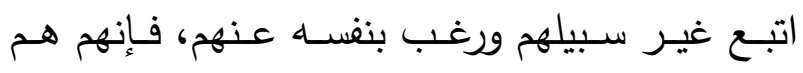

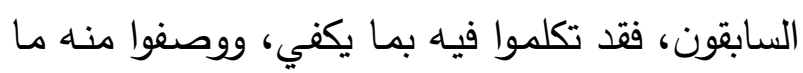

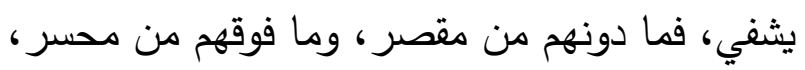

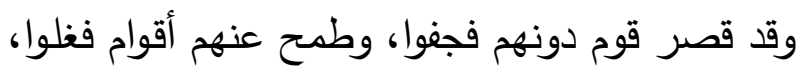

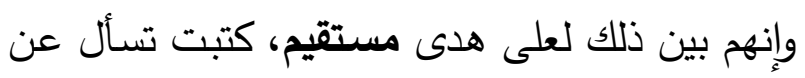

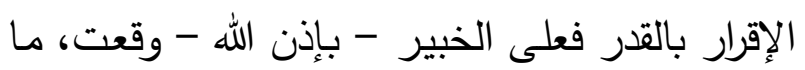

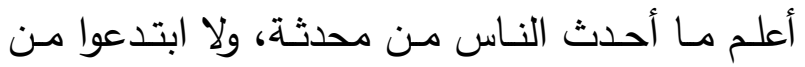

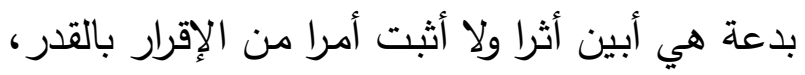

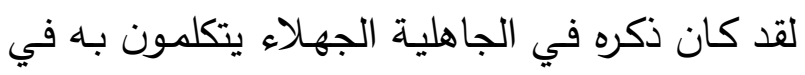

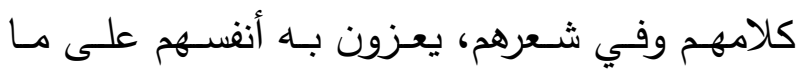

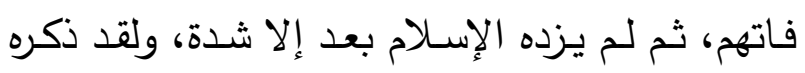

بينهم إلى يوم القيامة، وبقوا في شك منه مريب، وإذا كانت هذه حالهم مـع كتابهم، فمـ القرآن الذي أوحاه

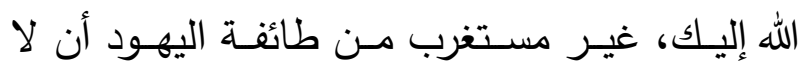
يؤمنوا به، وأن يكونوا في شك منهه مريب، ((وإن كحلا

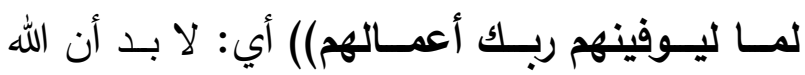
يقضي بينهم يوم القيامة بحكمه العدل، فيجازي كلاً

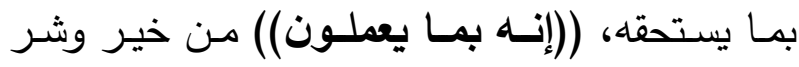
((خبيز)) فلا يخفى عليه شيء من أعمالهم، دقيقها

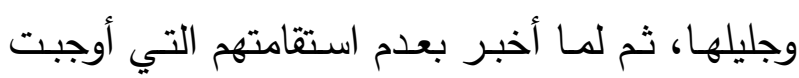

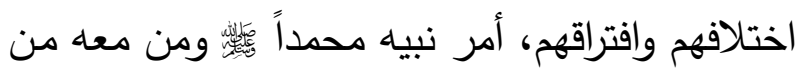

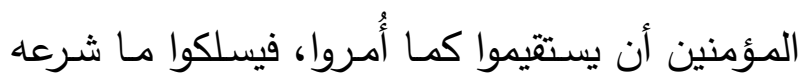
الله من الثرائع، ويعتقدوا ما أخبر الله به من العقائد

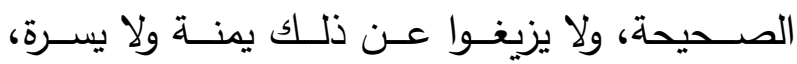

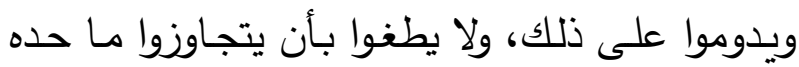
الله لهم من الاستقامة" (1).

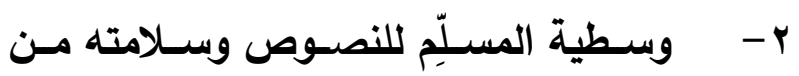
الغلو والجفاء ومن التخبط والثك والاضطراب:

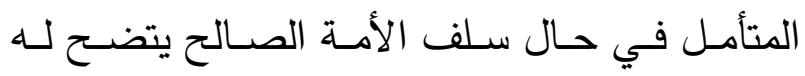

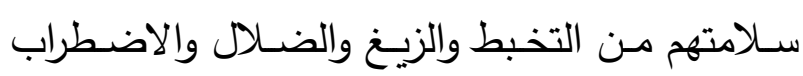

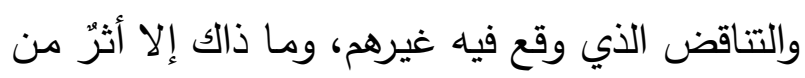

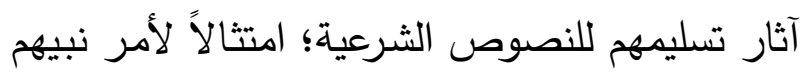
لَ

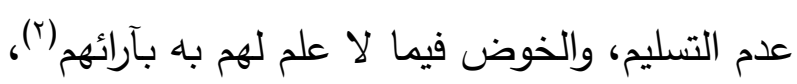

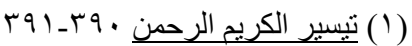

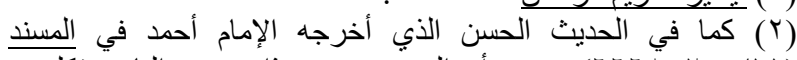

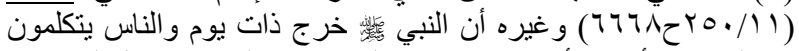

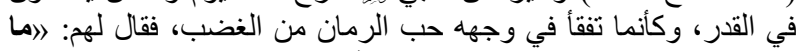

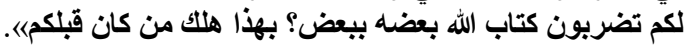




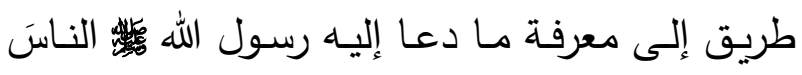
مـن الـدين المســققيم والصـراط المســقيم إلا هـــا الطريـق الذي سـلكه أصـحاب الحديث، وأمـا سـائر الفـرق فطلبـوا الـدين لا بطريقــ؛ لأنهـم رجعـوا إلـى معقولهم وخواطرهم وآرائهم فطلبوا الدين من قِبله، فإذا سمعوا شيئًاً من الكتاب والسنة عرضوه على معيار قلوبهم، فـإن استقام قبلـوه، وإن لـم يسـتقم في ميزان عقولهم ردوه... وأما أهل الحق فجعلوا الكتاب والسنة إمامهم، وطلبوا الدين من قِبلهما، وما وقع لهم من معقولهم وخواطرهم عرضوه على الكتاب والسنة، فإن وجدوه موافقاً لههـا قبلوه.... وإن وجدوه مخالفـاً لهمـا تركوا ما وقع لهم، وأقبلوا على الكتاب والسنة، ورجعوا بالتهمة على أنفسهم؛ فإن الكتاب والسنة لا يهديان إلا إلى الحق، ورأي الإنسان قد يرى الحق، وقد يرى

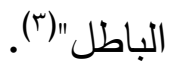
وقال شيخ الإسـلام ابن تيميـة رحمه الله بعد أن ساق جملـة مـن أحاديث الصفات: "فإن الفرقة الناجيـة أهلَ السنة والجماعة - يؤمنون بذلك كما يؤمنون بما أخبر الله به في الكتاب العزيز ، من غير تحريف ولا تعطيل، ومن غير تكييف ولا تمثيل، بل هم الوسط

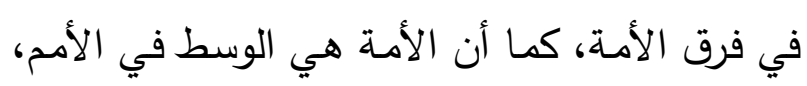
فهم وسط في باب صفات الله سبحانه وتعالى بين

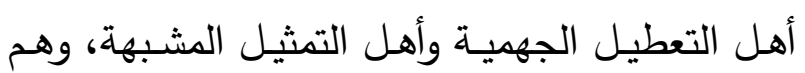
وسطٌ في باب أفعال الله تعالى بين القدريـة والجبريـة، وفي باب وعيد الله بين المرجئة والوعيدية من القدريـة
رسول الله منه المسلمون فتكلموا به في حياته وبعد وفاته، يقينا وتسليما لربهم، وتضعيفاً لأنفهه، أن يكون شيء لم يحط بـه علمـه، ولم يحصــه كتابـه، ولم يمض فيـه قدره، وإنـه مـع ذلك لفي محكم كتابه: منـه اقتبسوه، ومنه تعلموه، ولئن قلتم: لم أنزل الله آية كذا؟ لم قال كذا؟ لقد قرؤوا منـه مـا قرأتم، وعلموا من تأويلـه مـا جهلتم، وقالوا بعد ذلك: كله بكتاب وقدر ، وكتبـ الشقاوة، وما يقدر يكن، وما شاء الله كان وما لم يشأ لم يكن، ولا نملك لأنفسنا ضراً ولا نفعا، ثم رغبوا بعد ذلك ورهبوا" ('). وقـال الطحـاوي رحمــهـ الله: "ولا تثبـت قـدم الإســلام إلا على ظهر التسـليم والإســلام، فـن رام

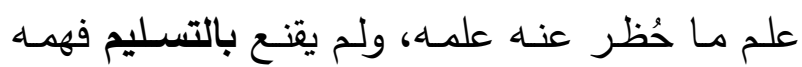
حجبـه مرامسه عن خالص التوحيد، وصـافي المعرفة،

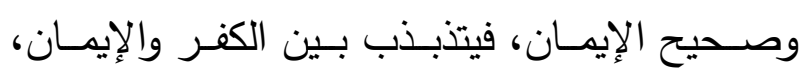
والتصديق والتكذيب، والإقرار والإنكار ، موسوسا تائهاً شاكاً، لا مؤمناً مصدقاً، ولا جاحداً مكذباً"(؟). وجاء في الحجة في بيان المحجة: "... غير أن الله أبسى أن يكون الحق والعقيدة الصـحيحة إلا مـع أهل الحديث والآثار ؛ لأنهم أخذوا دينهم وعقائدهم خلفاً عـن سـلفٍ وقرنـاً عـن قـرنٍ، إلـى أن انتهـوا إلـى لـى التابعين، وأخذه التابعون من أصحاب رسول الله وأخذه أصسحاب رسول الله

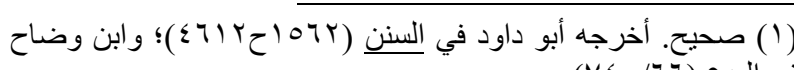

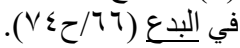

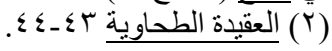


الشهوات التي تعارض أوامر الله وأوامر رسوله لئسل، فجمعوا بذلك بين تصديق الأخبار والإيمان بها في صفات الله وأفعاله وما أخبر به عن اليوم الآخر وغير ذلك، وبين طاعة الأوامر والانقياد والإذعان لها، وأعرضوا عن شبهات المتكلمين الباطلة، وسلمِوا بتسليمهم لمن بيده أزمَّة الأمور من منازعة الملك العزيز ، ومن معارضة العليم الحكيم في قدره وشرعها، فهم لا يرون في شرعٍ شرعه الله، أو قدرٍ قدره أن مقتضى الحكمة خلافه، وهم بذلك أصحاب القلوب السليمة، المستقيمون على الحق، الناجون في الدنيا من الضلال، وفي الآخرة من عامة الأهوال("). وإذا كانت الأشياء تتميز بضدها، فكما أن للتسليم للنصوص الثرعية أثراً عظيماً في استقامة العقيدة الإسلامية من الزيخ والاضطراب فكذلك للإعراض عن تلك النصوص أثزر عظيمٌ في اضطراب عقيدة المعرضين وزيغها واعوجاجها.

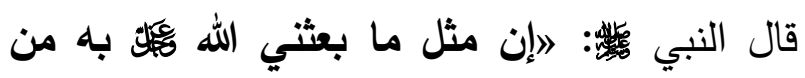
الههى والعلم كمثل غيث أصاب أرضاً، فكانت منها طائفة طيبة، قبلت الماء فأنبتت الكلأ والعثب الكثير، وكان منها أجادب أمسكت الماء فنفع الله بها الناس، فثربوا منها وسقوا ورعوا، وأصاب طائفةً منها أخرى، إنما هي قيعان لا تمسك ماء ولا تنبت كلاً، فذلك مثل من فقه في دين الله ونفعه الله بما بعثي الله به فعلم وعلَّم، ومثل من لم يرفع بذلك
وغيـرهم، وفـي بـاب أســـاء الإيمـان والـدين بـين الحروريــة والمعتزلــة وبـين المرجئـة والجهميـة، وفي ولي أصسحاب رسـول الله بكس بـين الروافض والخـوارج" (')، وسـئل عن قولـه في صـات الله تعـالى فقـال: "قولنـا فيها مـا قاله الله ورسوله وله والسـابقون الأولون من المهاجرين والأنصار والذين اتبعوهم بإحسان.... وهذا هو الواجب على جميع الخلق في هذا الباب وغيره،

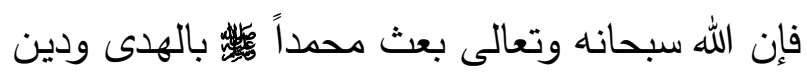
الحق ليخرج الناس من الظلمات إلى النور ... وشهد

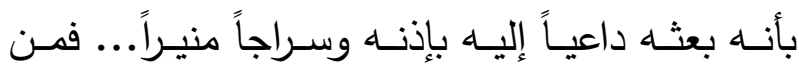
المحـال فـي العقل والـدين أن يكـون السـراج المنيـر الـذي أخـرج الله بـه النـاس مـن الظلمـات إلـى النـور

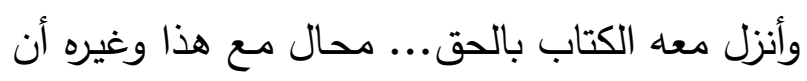
يكون قد ترك بـاب الإيمـان بـالله والعلـم بـه ملتبسـاً

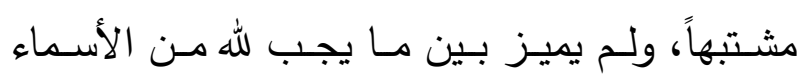
الحسنى والصفات العليا، وما يجوز عليه، وما يمتنع عليه؛ فإن معرفة هذا أصل الدين، وأسـاس الهداية، وأفضل وأوجب ما اكتسبته القلوب، وحصلته النفوس،

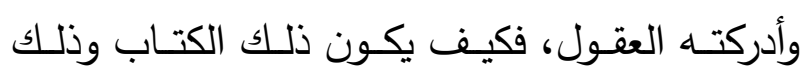
الرسول وأفضل خلق الله بعد النبيين لـ يحكموا هذا الباب اعتقادا وقولاً ؟!"(r). وأهل السنة والجماعة تخلصوا بتسليمهم للنصوص الشرعية من اتباع الشبهات الفاسدة التي تعارض أخبار الله وأخبار رسوله لكّلة، وتخلصوا من اتباع 
كنت أقول له: حدثني عن فهمك هذا الذي رفعت به أمر النار على الطين أهو وهبه لك ؟ أم حصل لك من غير موهبته ؟ فإنه سيقول: وهبه لي، فأقول: أفيهب لك كمال الفهم الذي لا تدركه حكمته، فترى أنت الصواب ويرى هو الخطأ؟!"(v)، ثم قال: "واعلم أن المعترض قد ارتفع أن يكون شريكاً، وعلا على الخالق بالتحكم عليه، وهؤلاء كلهم كفرة(^)؛ لأنهم رأوا حكمة الخالق قاصرة، وإذا كان توقف القلب عن الرضى بحكم الرسول تعالى: (( فلا وربك لا يؤمنون حتى يحكموك فيما شجر بينهم ثم لا يجدوا في أنفسهم حرجًا مما قضيت ويسلموا تسليمًا )(9) فكيف يصح الإيمان مع الاعتراض على الله تعالى؟... ففي عقولنا قوة التسليم، وليس فيها قدرة الاعتراض عليه... ومن علم أن الله تعالى مالكُّ وحكيم وأن حكمته قد تخفى؛ سلَّم لما لم يعلم علته، فأفعاله مسلَّمةٌٌ إلى مانى حكمته"(')

وبين ابن القيم رحمه الله أن الاعتراض على نصوص الشرع وعلى أفعال الله تعالى وأحكامه أربعة أنواع

"سارية في الناس، والمعصوم من عصمده الله منها: النوع الأول: الاعتراض على أسمائه وصفاته بالثبه

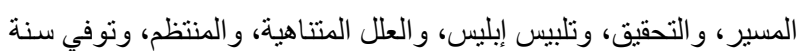

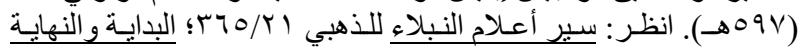

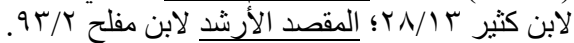

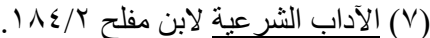

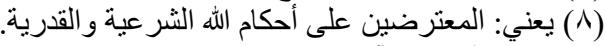

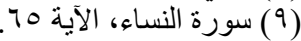

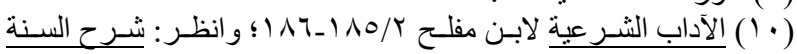

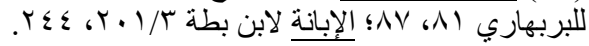

رأساً ولم يقبل هدى الله الذي أرسلت بهی(').

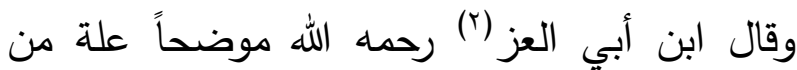

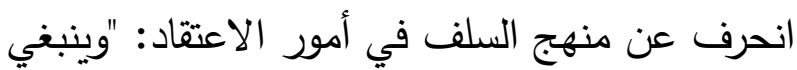
أن يُعرف أن عامة من ضل في هذا الباب، أو عجز فيه عن معرفة الحق، فإنما هو لتقريطه في اتباع ما جاء به الرسول، وترك النظر والاستدلال الموصل إلى معرفته، فلما أعرضوا عن كتاب الله ضلوا، كما لها قال تعالى: ((فإما يأتينكم مني هدى فمن تبع هداي فلا يضل ولا يثقى (rT I ) ومن أعرض عن ذكري فإن له معيشة ضنكاً ونحشره يوم القيامة أعمى لهم ( צ Y 1) قال رب لم حشرتني أعمى وقد كنت بصيراً

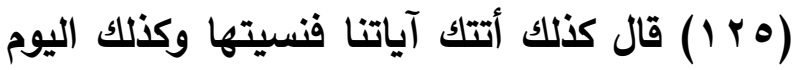

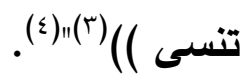
وغالب ضلال من ضل عن الحق هو بسبب بعده عن التسليم، واعتراضه بعقله القاصر على الحكيم العليم، وأول سالكٍ في سبيل المشاقة والاعتراض هو إبليس؛ "فإنه نظر بمجرد عقله فقال: كيف تفضل الطين على جوهر النار؟ وفي ضمن اعتراضه أن حكمتاك قاصرةٌ، وأن رأيي أجود" (o) قال ابن الجوزي(؟) رحمه الله: "فلو لقيت أنا إبليس،

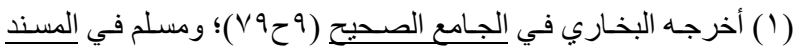

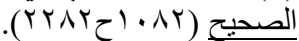

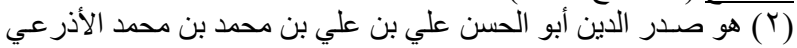

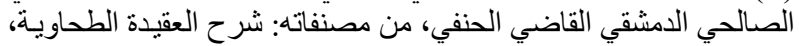

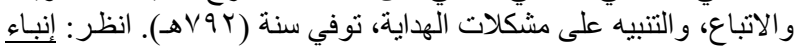

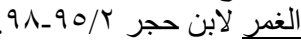

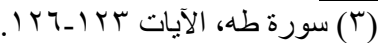

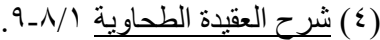

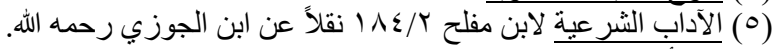

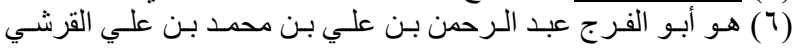

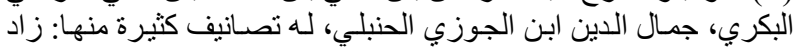


طائفة قبالة دين الله وشرعه طاغوتاً يتحاكمون إليه، فهولاء يقولون: لكم النقل ولنا العقل، والآخرون يقولون: أنتم أصحاب آثار وأخبار، ونحن أصحاب

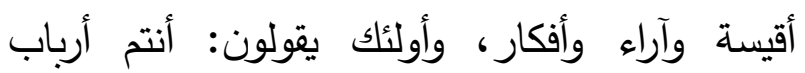
الظاهر، ونحن أهل الحقائق، والآخرون يقولون: لكم ولكرون

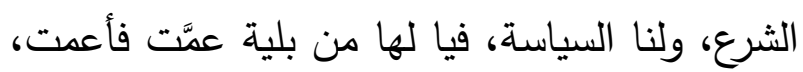

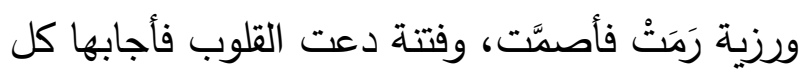
قلب مفتون، وأهوية عصفت فصُمَّت منها الآذان، ونهان وعميت منها العيون، عُطلت لها والله معالم الأحكام، وله كما نفيت لها صفات ذي الجلال والإكرام، واستتد كل قوم إلى ظلم وظلمات آرائهج، وحكموا على الله

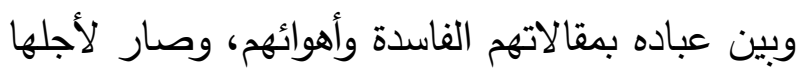

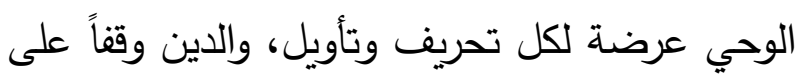
كل إفساد وتبديل. النوع الرابع: الاعتراض على أفعاله وقضائه وقدره،

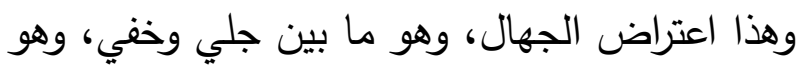

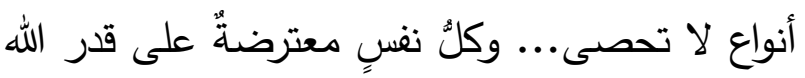

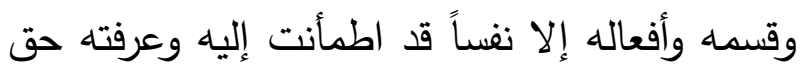
المعرفة التي يمكن وصول البشر إليها، فتلك حظها التسليم والانقياد والرضى كل الرضى" (')

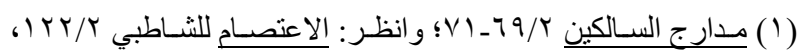

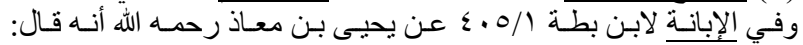

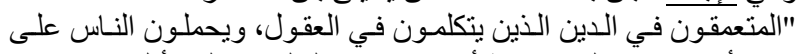

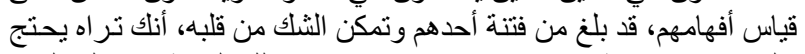

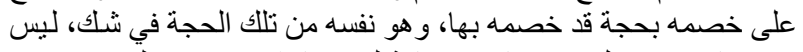

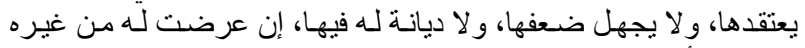

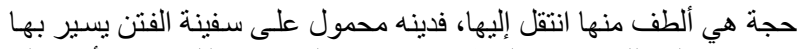

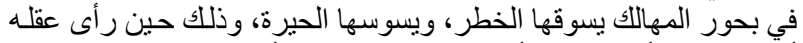

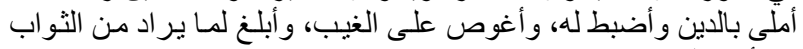

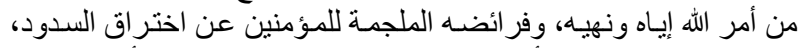

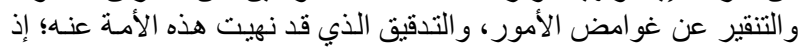

الباطلة التي يسميها أربابها قواطع عقلية، وهي في الحقيقة خيالات جهلية، ومحالات ذهنية، اعترضوا لهابها

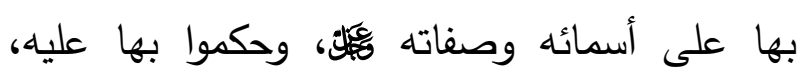

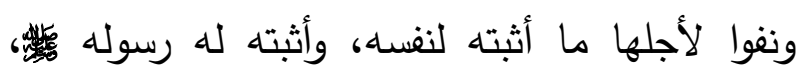
وأثثتوا ما نفاه...

والعاصم من هذا الاعتراض التسليم المحض للوحي،

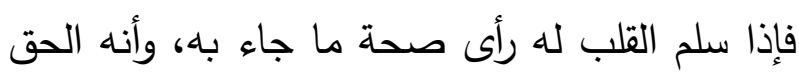
بصريح العقل والفطرة، فاجتمع له السمع والعقل

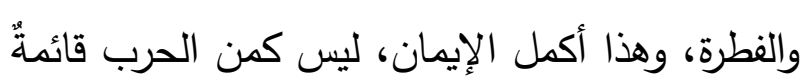

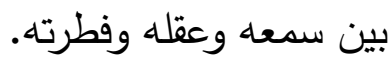
النوع الثاني: الاعتراض على شرعه وأمره بأه والراي والقياس، أو بالأذواق والمواجيد والخيالات والكشوفات

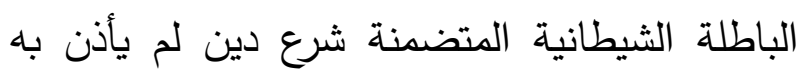
الله، وإبطال دينه الذي شرعه على لسان رسوله والتعوض عن حقائق الإيمان بخدع الثيطان وحظوظ النفوس الجاهلة... النوع الثالث: الاعتراض على ذلك بالسياسات الجائرة التي لأرباب الولايات التي قدموها على حكم الله ورسوله لك: وحكما بها بين عباده، وعطلوا لها وبها شرعه وعدله وحدوده. فقال الأولون: إذا تعارض العقل والنقل قدمنا العقل، وقال الآخرون: إذا تعارض الأثر والقياس قدمنا القياس، وقال أصحاب الذوق والكثف والوجد: إذا تعارض الذوق والوجد والكثف وظاهر الشرع قدمنا

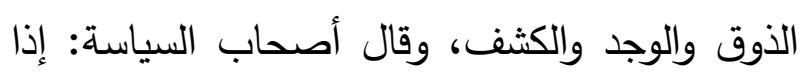

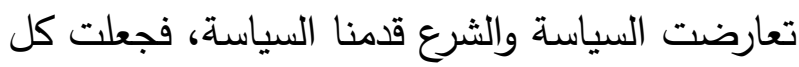


القرآن والسنة وتقديمها على ما سواهما لخير شاهد على سلامة عواقب طريق التسليم لهما(؟)، ومن ذلك قول فخر الدين الرازي(؛) رحمه الله في وصيته في آخر حياته: "لقد اختبرت الطرق الكلامية فما رأيت فيها فائدة تساوي الفائدة التي وجدتها في القرآن العظيم؛ لأنه يسعى في تسليم العظمة والجلال بالكلية الله تعالى، ويمنع عن التعمق في إيراد

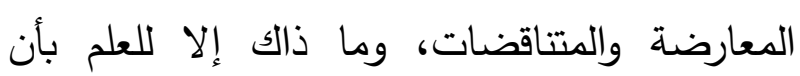
العقول البشرية تتلاشى وتضدحل في تلك المضايق العميقة، والمناهج الخفية"(•).

\section{الخاتمة}

بعد حمد الله تبارك وتعالى والثناء عليه كما ينبغي

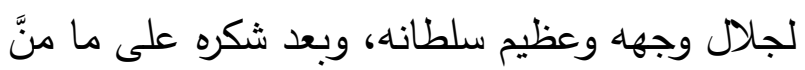

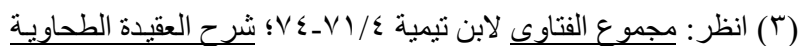

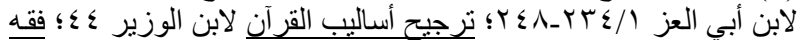

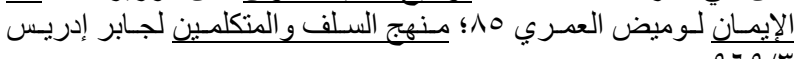
ومن أشهر من اشتغل بمناهج المتكلمين بعلم الكلام والفلسفة والمنطق

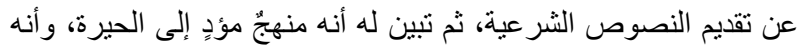

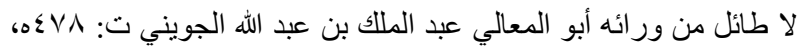
و أبو حامد الغزالي ت:

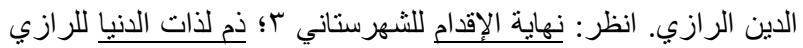

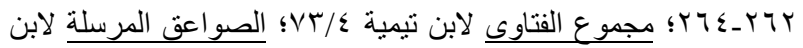

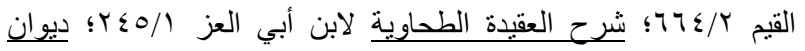
الصنعاني و عن الجويني و الغزالي و الرازي يقول الشوكاني رحمه الله في إرشاد

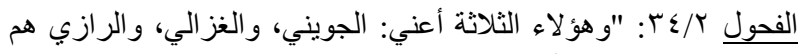

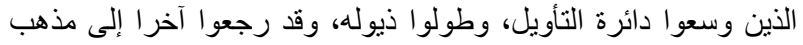

السلف كما عرفت، فلله الحمد كما هو لله أهل".

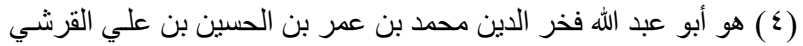

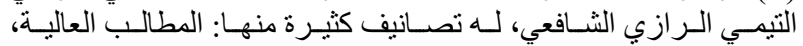

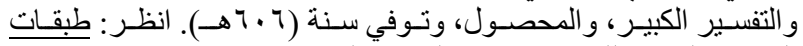

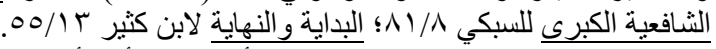

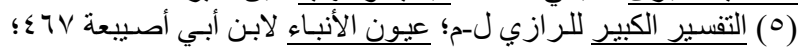

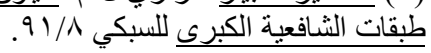

وإننا لنجد الذين طلبوا علم الاعتقاد من غير طريق النصوص الشرعية، ولكن بطرق علم الكلام، واعترضوا بقوانينه على نصوص الشرع فردوها، أو أولوها بما يوافق أهواءهم وآراءهم - نجدهم قد تحيروا لتهرو

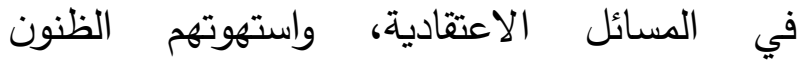
والاحتمالات، وحرموا من الهدى في كثيرٍ من

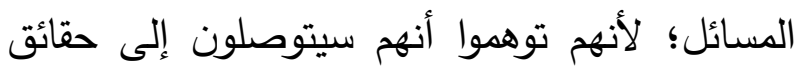

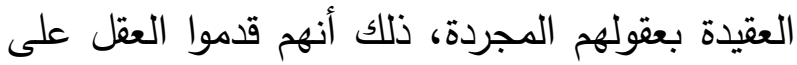

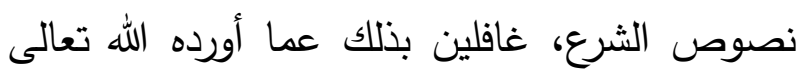
في كتابه من مثل قوله: (وكذلك أوحينا إليك روحاً

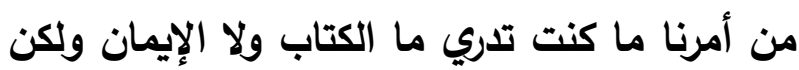

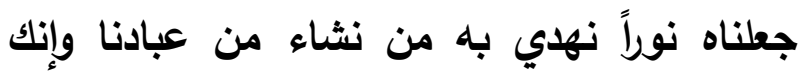

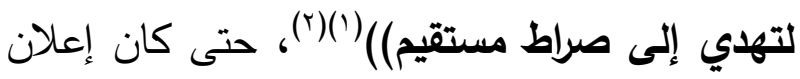
كثيرٍ ممن لم يسلموا للقرآن والسنة وقدموا عليهما غيرهما في مسائل العقيدة والاستدلال عليها لنيل الندمَ والحسرة على ما مضى وهم في بعدهم عن نصوص

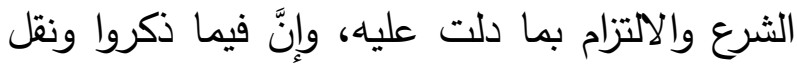
عنهم من حرصٍٍ على العودة إلى التسليم بنصوص لصن

كان ذلك سبب هلاك الأمم قبلها، و علة ما أخرجها من دين ربها، و هؤ لاء

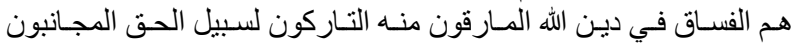

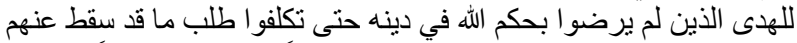

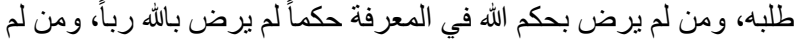

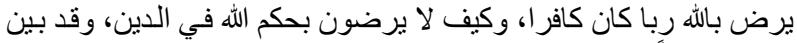

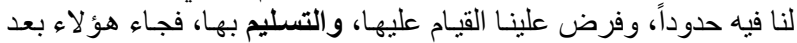

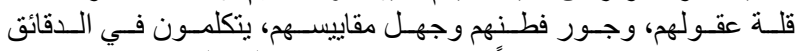

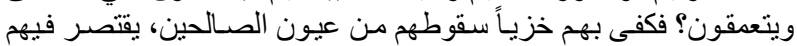

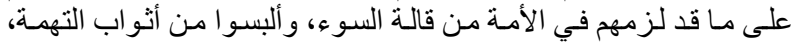

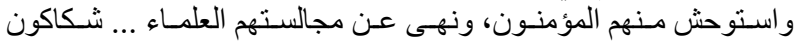

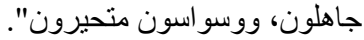

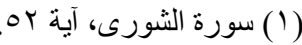

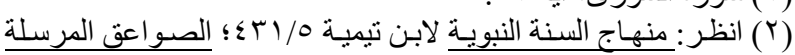
لابن القيم 
إنما كان التسليم شرطاً في استقامة العقيدة من

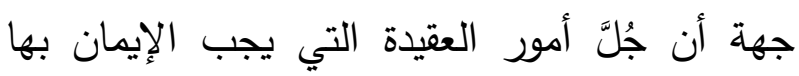
غيب.

لما افترق أهل البدع على طرفي نقيض بين

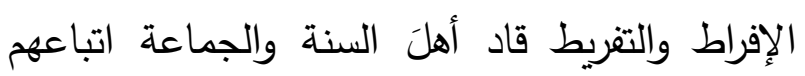

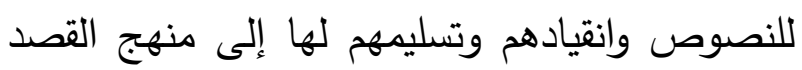
والتوسط والاستقامة.

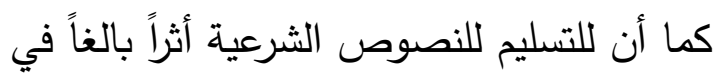

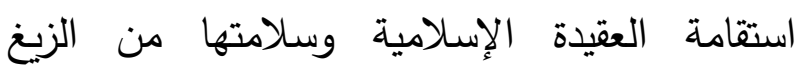

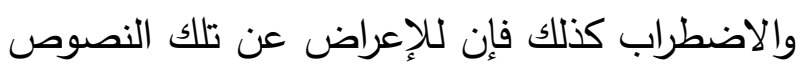
أثراً عظيماً في اعوجاج عقيدة المعرضين وزيغها. غالب ضلال من ضل عن الحق في مسائل الاعتقاد وغيرها هو بسبب بعده عن التسليم للنصوص الشرعية. والحمد لله الذي بنعمته تتم الصالحات، وصلى الله وسلم وبارك على عبده ورسوله نبينا محمد بن عبد الله، وعلى آله وصحبه أجمعين. فهرس المصادر والمراجع

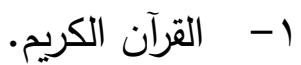
r- الإبانة عن شريعة الفرقة الناجية ومجانبة الفرق المذمومة (الكبرى). أبو عبد الله عبيد الله بن الإبه

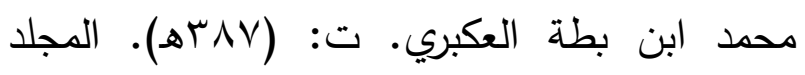
الأول والثاني تحقيق: رضا بن نعسان معطي.

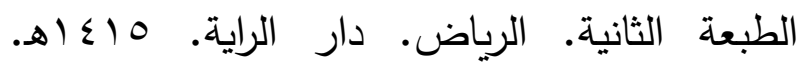
المجلد الثالث تحقيق: الوليد بن محمد. الطبعة الأولى. الرياض. دار الراية. 1 (اء اله.
به عليَّ من إتمام هذا البحث، أسجل أهم النتائج التي خرجت بها، وهي على النحو التالي: أن المراد بـ (التسليم للنصوص الثرعية وأثثره في استقامة العقيدة) هو الانقياد والإذعان لآيات القرآن الكريم وأحاديث السنة المطهرة، وثمرة ذلك وما ينتج عنه من اعتدال اعتقاد الإنسان وصوابه، وصحة إيمانه، وتوسطه في باب الاعتقاد بين الغالي

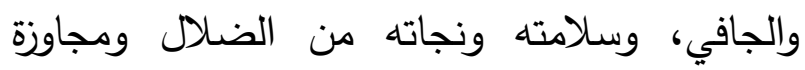
حدود الله. التسليم لأحكام الله تعالى ورسوله

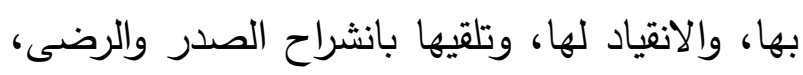

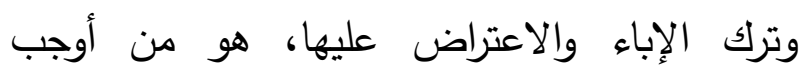
الواجبات التي فرضها الله على عباده. أدلة وجوب التسليم للنصوص الشرعية كثيرةٌ ظاهرةٌ في كتاب الله تعالى وسنة نبيه تضافر أقوال علماء السلف على وجوب التسليم للنصوص الثرعية، وما يتضمنه ذلك التسليم. جعل أهل السنة والجماعة القرآن الكريم والسنة النبوية هما العمدة في مصادر تلقي العقيدة طلباً

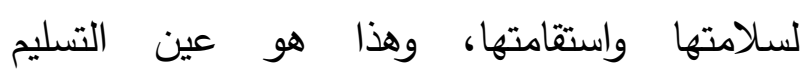
للنصوص الثرعية. للتسليم للنصوص الشرعية آثار جليلةٌ ونتائج عظيمة تتحقق بمقدار ما يتحقق من ذلك التسليم.

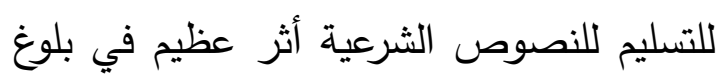
الهداية والاستقامة وسلوك سبيل النجاة. 
• 1- الأدلة العقلية النقلية على أصول الاعتقاد. سعود العريفي. الطبعة الأولى. مكة المكرمة. دار عالم الفوائد. 9 إـ (هـ. r- إثبات الثفاعة ـ شمس الدين محمد بن أحمد

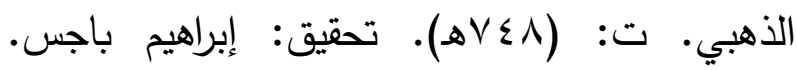

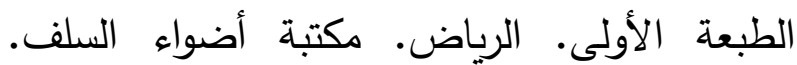

ه) $\leqslant r$.

الأصول. محمد بن علي بن محمد الثوكاني. ت:

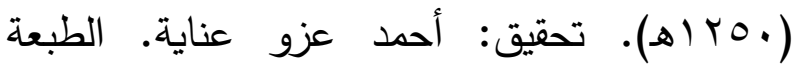

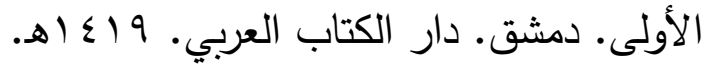

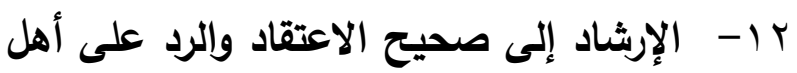
الثرك والإلحاد. صالح الفوزان. الطبعة الثالثة. الرياض. دار ابن خزيمة. . . ؟ أهـ.

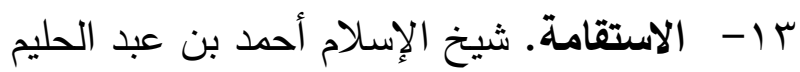
ابن تيمية.ت: (هY^A). تحقيق: محمد رشاد سالم.

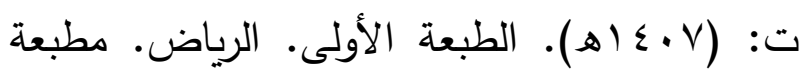

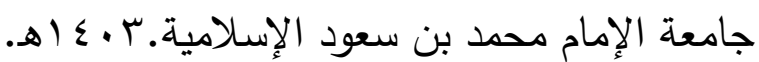

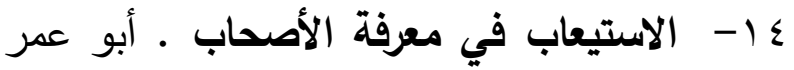
يوسف بن عبد الله بن محمد بن عبد البر النمري القرطبي ت: (ب آــه). تحقيق: علي محمد البجاوي. ت: (99 9 أه). الطبعة الأولى. بيروت. دار الجيل. هـ

10- الإصابة في تمييز الصحابة. أحمد بن علي

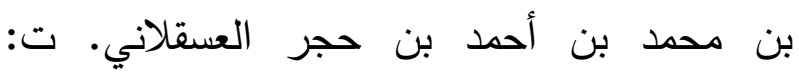

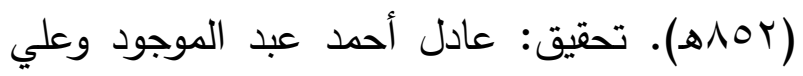

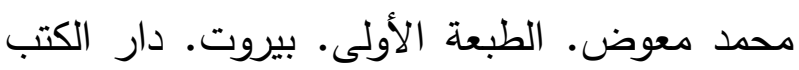
العلمية. 0 إ أهـ
ـ- أحكام القرآن. أبو بكر أحدد بن علي الرازي

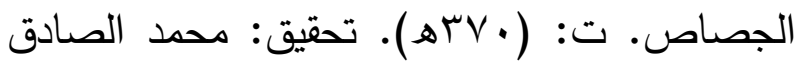

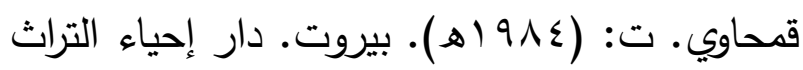
العربي. 0 • ؛ اهـ. اله. 0- الإحكام في أصول الأحكام. أبو محمد علي

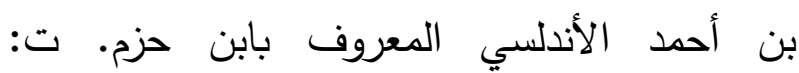

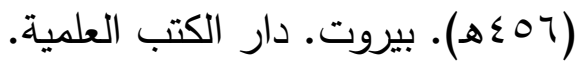

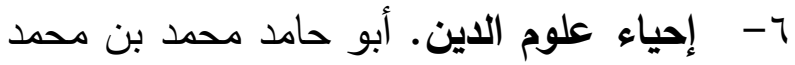

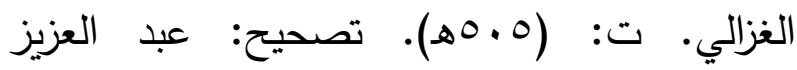
السيروان. الطبعة الثالثة. بيروت. دار القلم. - - أخبار مكة في قديم الدهر وحديثه. أبو عبد

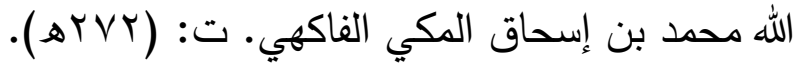

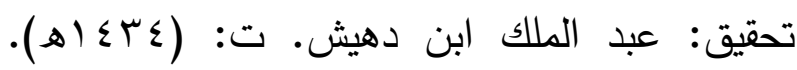
الطبعة الثانية. بيروت. دار خضر. ع إعا اهـ. 1- اختلاف الدديث. مطبوع مع كتاب الأم. أبو عبد الله محمد بن إدريس الثافعي. ت: (ع ·rهـ).

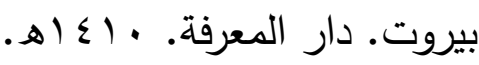
9- الآداب الثرعية. أبو عبد الله محمد بن مفلح

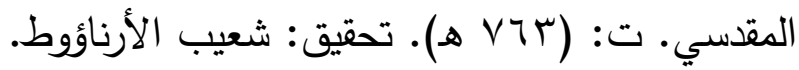

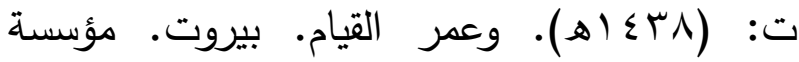
الرسالة. 9 (إ) اهـ. 
17 - أصول السنة. أحمد بن محمد بن حنبل منها. ناصر عبد الكريم العقل. الطبعة الثانية.

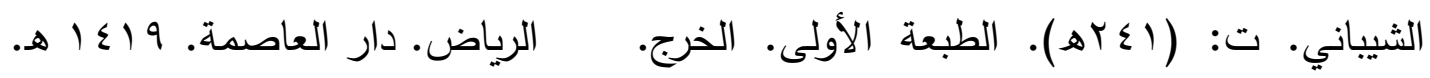

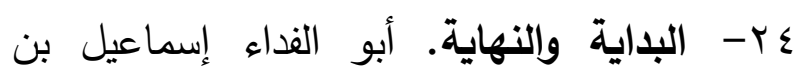

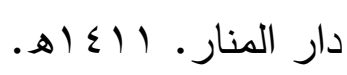

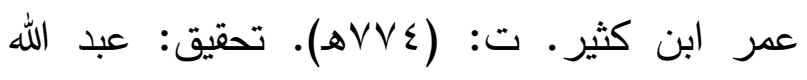

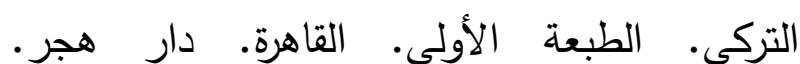
. $1 \leqslant$.

ه ب- بدائع الفوائد. أبو عبد الله شمس الدين محمد

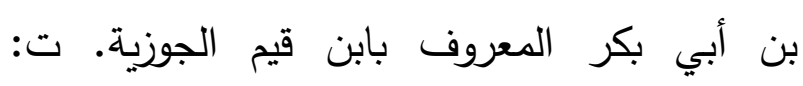

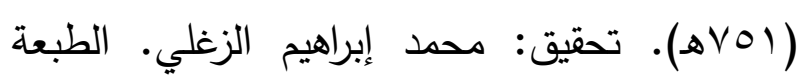

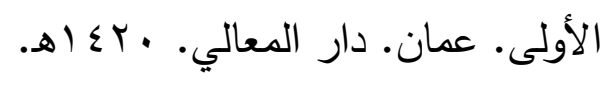

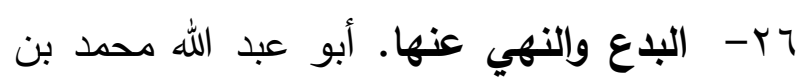

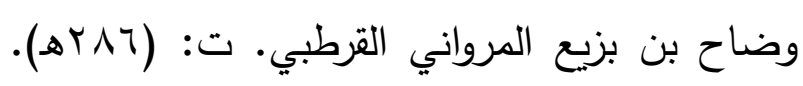

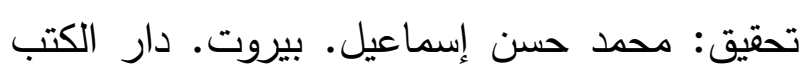

ت تاج التراجم. أبو الفداء قاسم بن قُطلُوبغا

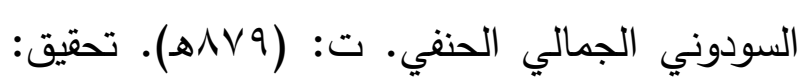
محمد خير رمضان يوسف. الطبعة الأولى. دمشق.

دار القلم.r إع أه. ^ץ- - تاريخ الطبري (تاريخ الرسل والملوك). أبو

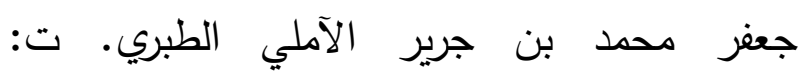

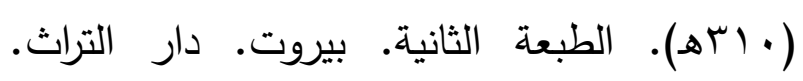
. ITNV

و ج- تاريخ بذاد. أحمد بن علي الخطيب

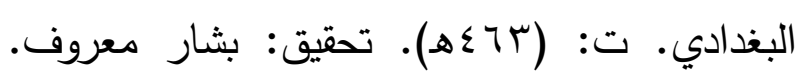

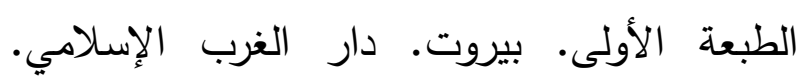

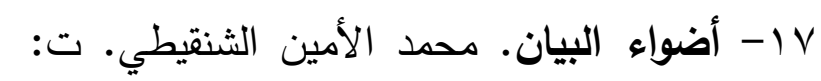

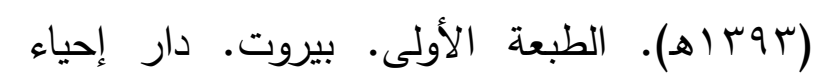

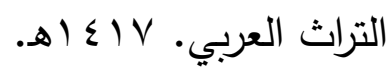
11- الاعتصام. أبو إسحاق إبراهيم بن موسى اهربى الثاطبي. ت: ( •VQهـ). تحقيق: محمد الثقير. وسعد آل حميد. وهشام الصيني. الطبعة الأولى.

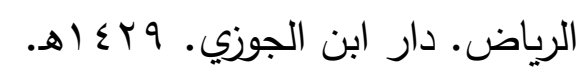

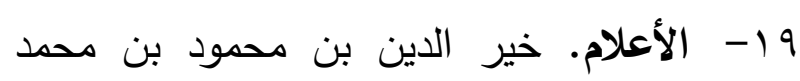
الزركلي. ت: (797 (ه). الطبعة الثالثة عشرة. بيروت. دار العلم للملايين. 991 ام. م. • ب- إكمال المعلم بفوائد مسلم. أبو الفضل عياض بن موسى بن عياض اليحصبي السبتي. ت: (ـ ــهـ). تحقيق: يحيى إسماعيل. الطبعة الأولى.

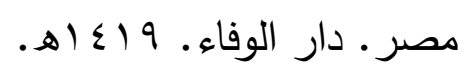

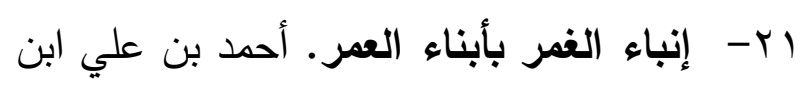
حجر العسقلاني. ت: (ب010ه). الطبعة الثانية. بيروت. دار الكتب العلمية. 7 . أهـ اله.

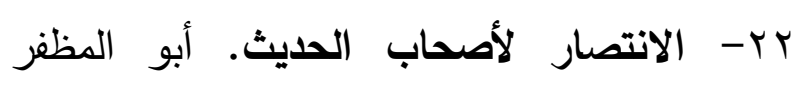

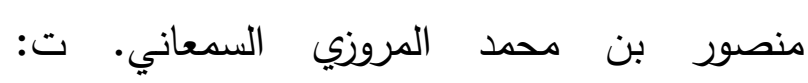
(الهی §هـ). تحقيق: محمد بن حسين الجيزاني. الطبعة

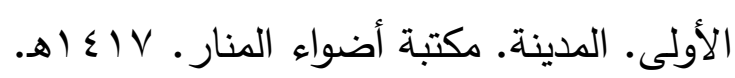

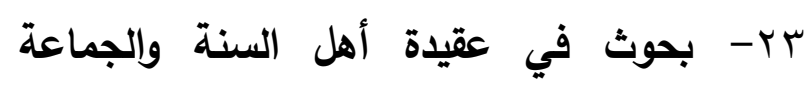
وموقف الأثاعرة والحركات الإسلامية المعاصرة 
الرحمن. الطبعة الأولى. بيروت. المكتب الإسلامي. هـ 0 ^ץ- تفسير القرآن العظيم مسنداً عن رسول الله  المعروف بابن أبي حاتم الرازي. ت: (ITVA). تحقيق: أسعد محمد الطيب. الطبعة الثانية. مكة المكرمة - الرياض. مكتبة نزار مصطفى الباز. . 1 \& 9 q ب- تفسير القرآن العظيم. عماد الدين إسماعيل بن عمر بن كثير القرشي. ت: (هV (هـ). بيروت.

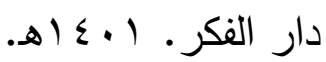

• ع- التفسير الكبير. فخر الدين محمد بن عمر بن حسين الرازي. ت: (7 · جهـ). الطبعة الثالثة. بيروت. دار إحياء التراث العربي. اء- - تفسير عبد الرزلق. أبو بكر عبد الرزاق بن همام بن نافع الحميري اليماني الصنعاني. ت: (IIII). تحقيق: د. محمود محمد عبده. الطبعة الأولى. بيروت. دار الكتب العلمية. 9 أـ اهـ. r Y - تفسير مقاتل. أبو الحسن مقاتل بن سليمان الأزدي. ت: ( •.0ه). تحقيق: أحمد فريد. الطبعة الأولى. بيروت. دار الكتب العلمية. ع ؟ أهـ. rی- التمهيد. يوسف بن عبد الله ابن عبد البر النمري. ت: (بآـه) · تحقيق: مصطفى أحمد العلوي ومحمد البكري. المغرب. وزارة الأوقاف. . TNV
• ب- تاريخ مدينة دمشق. علي بن الحسن ابن

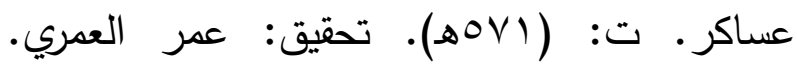
بيروت. دار الفكر • 990 (م. اس- التبصير في معالم الاين. أبو جعفر محمد بن جرير بن يزيد الآملي الطبري. ت: (·ـه). تحقيق: علي الشبل. الرياض. دار العاصمة. . (1) ץ- - تذكرة الحفاظ. شمس الدين محمد بن أحمد بن عثمان الذهبي. ت: (^^^^هـ). الطبعة الأولى. بيروت. دار الكتب العلمية. ؟ . ـ اهـ. سب- ترتيب المدارك وتقربب المسالك. أبو الفضل عياض بن موسى اليحصبي. ت: (ع § هـ). تحقيق: عبد القادر الصحراوي. الطبعة الأولى. المحمديةالمغرب. مطبعة فضالة. 979 (م. 97 ع - ترجيح أساليب القرآن على أساليب اليونان. محمد بن إبراهيم المعروف بابن الوزير الصنعاني.

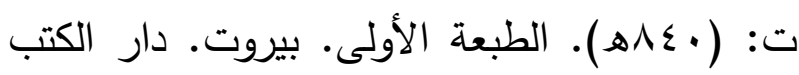
العلمية. ع ـ ع أهـ هr- التعريفات. علي بن محمد الجرجاني. ت:

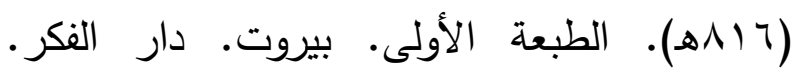
1 جس- تعظيم قدر الصلاة. محمد بن نصر المَرْوَزِي

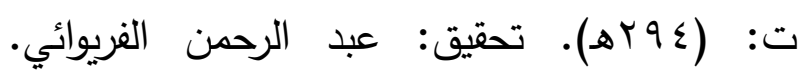
الطبعة الأولى. المدينة المنورة. 7 . ـ اهـ. اله. VV تغليق التعليق. أحمد بن علي ابن حجر الن العسقلاني. ت: (AOr). تحقيق: سعيد عبد 
10- جامع البيان عن تأويل آي القرآن. أبو جعر محمد بن جرير الطبري. ت: (• آسه). مكة البان المكرمة. دار التربية والتراث.

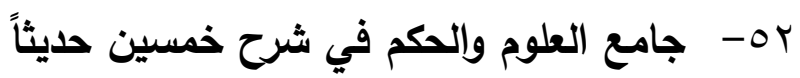
من جوامع الكلم. أبو الفرج عبد الرحمن بن شهاب

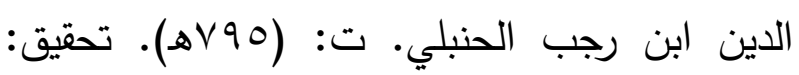

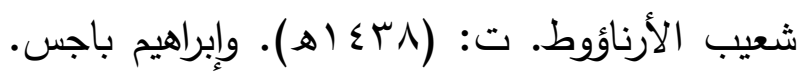

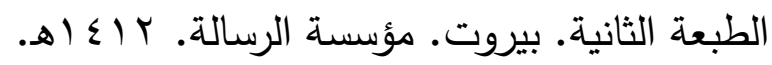
ro- الجامع المختصر من السنن عن رسول الله

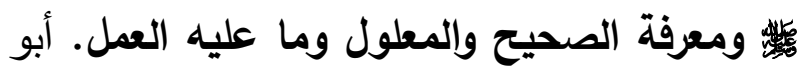
عيسى محمد بن عيسى بن سورة الترمذي. ت:

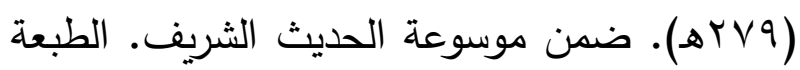

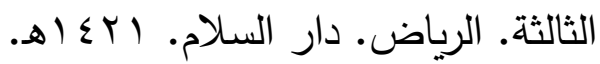

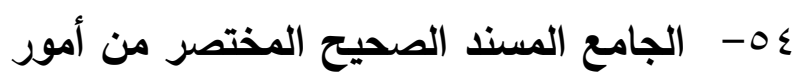

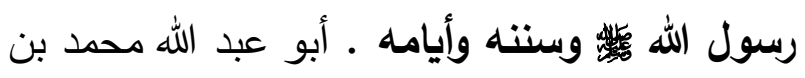

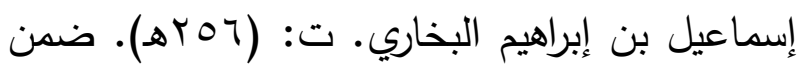
موسوعة الحديث الثريف. الطبعة الثالثة. الرياض.

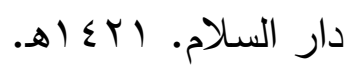

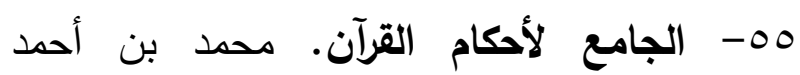

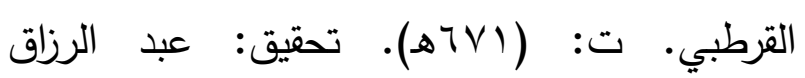

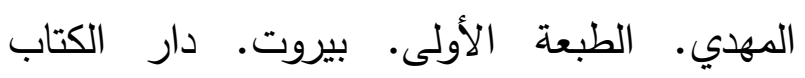

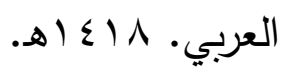
4- الجامع لأخلاق الراوي وآداب السامع. أبو بكر أحمد بن علي بن ثابت الخطيب البغدادي ت:

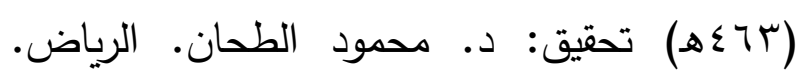
مكتبة المعارف.
؟ـ- تهذيب اللغة. أبو منصور محمد بن أحمد

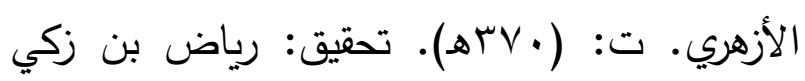

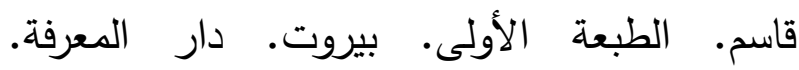
. (ه $\leqslant Y$ 0ـ- تهذيب الكمال في أسماء الرجال. جمال

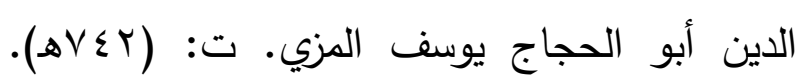
تحقيق: بشار عواد معروف. الطبعة الأولى. بيروت. مؤسسة الرسالة. . . . 1 أه.

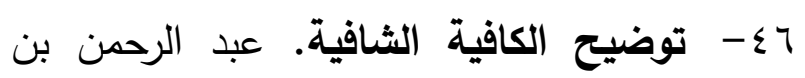

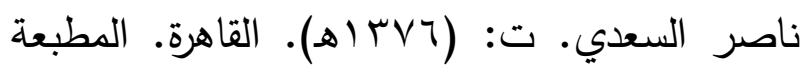
السلفية. §V الرؤوف المناوي. ت: (اس. (ه). تحقيق: محمد رضوان الداية. الطبعة الأولى. بيروت. دار الفكر الهر

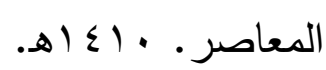
^ـ

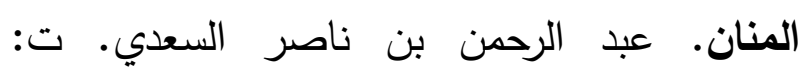

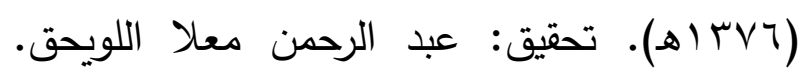

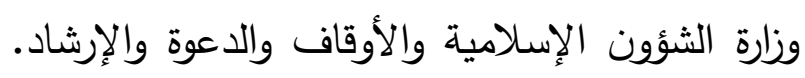
. ا $1 \leqslant$ I 9؟- الثقات. أبو الحسن أحمد بن عبد الله بن

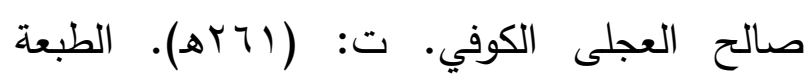
الأولى. دار الباز . 0 ـ ؛ اهـ. •- - الثقات. أبو حاتم محمد ابن حبان البستي.

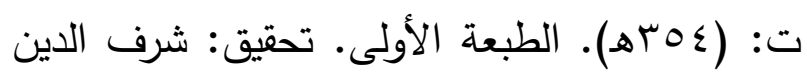

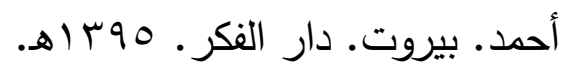


ع - ذا ذم الكلام وأهله. عبد الله بن محمد الهروي. ت: (1^^هـ). تحقيق: عبد الرحمن الشبل. الطبعة الأولى. المدينة. مكتبة العلوم والحكم. 1 (اء اهـ. ه - ذ ذم لذات الانيا. أبو عبد الله فخر الدين محمد بن عمر بن الحسين بن علي الرازي الثافعي. ت: (7 • 7 هـ). ليدن • مطبعة بريل. 7 . . بام.

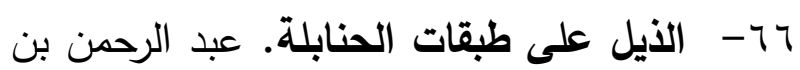
شهاب الدين ابن رجب الحنبلي. ت: (90 (هـ). تحقيق: محمد الفقي. ت: (IV^ اهـ). مكة المكرمة. المكتبة الفيصلية. V7 - رسالة إلى أهل الثغز بباب الأبواب. أبو الحسن علي بن إسماعيل الأشعري. ت: (ع باهـ). تحقيق: عبد الله شاكر الجندي. المدينة المنورة. مطبوعات الجامعة الإسلامية. با ع اهـ. 1 1- الرسالة. محمد بن إدريس الثافعي. ت:

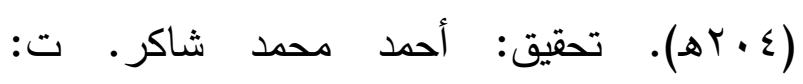

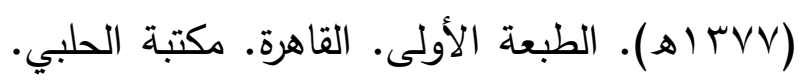

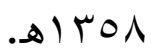

97- روضة الناظر. عبد الله بن أحمد ابن قدامة المقدسي. ت: (·rTهـ). تحقيق: عبد الكربم النملة. ت: (0باء اهـ). الطبعة الثالثة. الرياض. مكتبة الرشد. 0 إع أهـ. • - رياض الصالحين. أبو زكريا يحيى بن شرف النووي. ت: ( (7Vهـ). الطبعة الثالثة. بيروت. دار

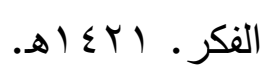

-OV بن العباس بن عثمان الثافعي القرشي المكي. ت:

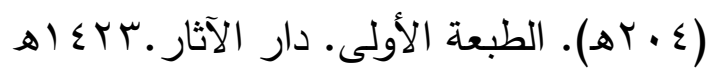
هـ- الحجة في بيان المحجة وشرح عقيدة أهل السنة. أبو القاسم إسماعيل بن محمد التيمي (قوام السنة). ت: (0بهـ). تحقيق: محمد ربيع المدخلي ومحمد محمود أبو رحيم. الطبعة الأولى. الرياض.

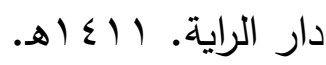
09- حلية الأولياء. أبو نعيم أحمد بن عبد الله الأصبهاني. ت: ( • بـهـ). الطبعة الرابعة. بيروت. دار الكتاب العربي. 0 . ؛ أه. • - خطبة الكتاب المؤمل للرد إلى الأمر الأول. أبو القاسم شهاب الدين عبد الرحمن بن إسماعيل بن إبراهيم المقدسي الدمشقي المعروف بأبي شامة ت:

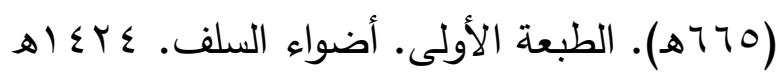
آ- درو تعارض العقل والنقل. أحمد بن عبد

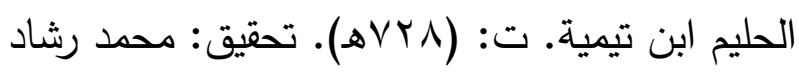
سالم. ت: (v • ع اهـ). الرياض. دار الكنوز الأدبية.

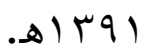
r الصنعاني الكحلاني. ت: (1) إه). الطبعة الأولى. القاهرة. مطبعة المدني. ع^با اهـ. بح- ذا التأويل. عبد الله بن أحمد ابن قدامة المقدسي. ت: (•rTه). تحقيق: بدر البدر. الكويت. الدار السلفية. 7 • ـ اهـ. 
السمر • وأكرم البوشي. الطبعة السابعة. بيروت.

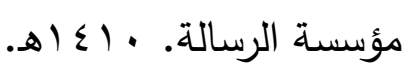
شرح أصول اعتقاد أهل السنة والجماعة -VV من الكتاب والسنة وإجماع الصحابة والتابعين من بعدهم. أبو القاسم هبة الله بن الحسن بن منصور

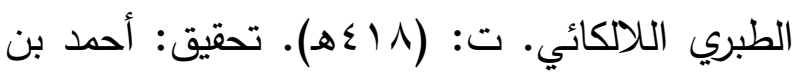

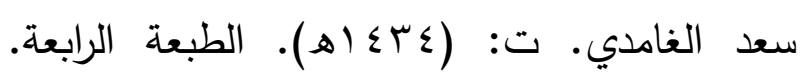

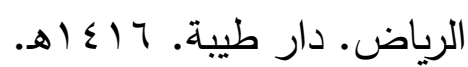
- VA

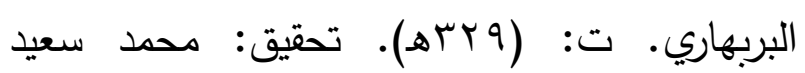
القحطاني. الطبعة الأولى. الدمام. دار ابن القيم. . 1 . 1

- Vq

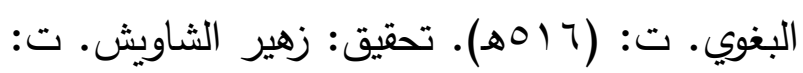

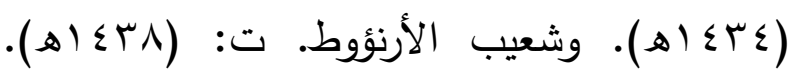
الطبعة الثانية. بيروت. المكتب الإبلامي. .

• ^- شرح العقيدة الطحاوية ـ علي بن علي بن

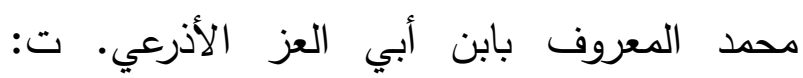
( ) ( PA). تحقيق: عبد الله التركي وشعيب الأرنؤوط.

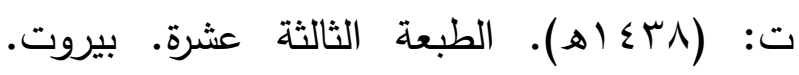

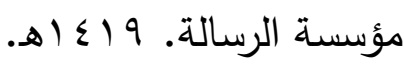
الي- شرح العقيدة الواسطية. محمد بن صالح

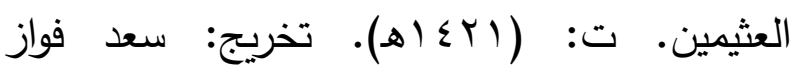
الصميل. الطبعة الثانية. الدمام. دار ابن الجوزي. . (ه) 10
الم- زاد المعاد في هدي خير العباد. أبو عبد الله شمس الدين محمد بن أبي بكر المعروف بابن قيم الجوزية. ت: (101) (هـ). تحقيق: شعيب الأرنؤوط.

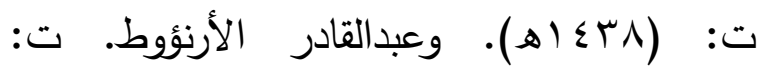

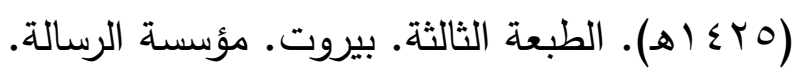
.ه 19 ع - زاد المهاجر إلى ربه (الرسالة التبوكية). أبو

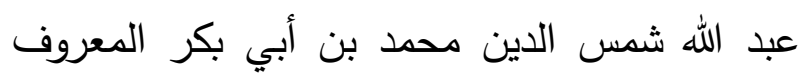

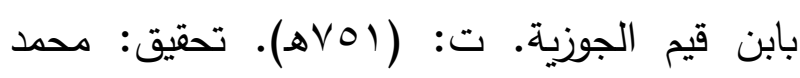

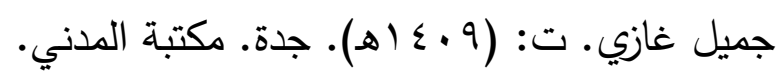
r - السنة. أحمد بن محمد بن هارون الخلال.

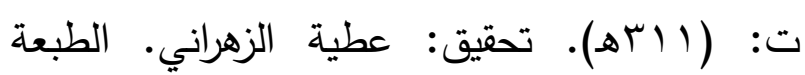

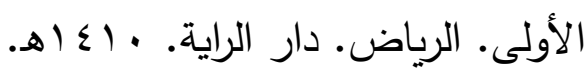

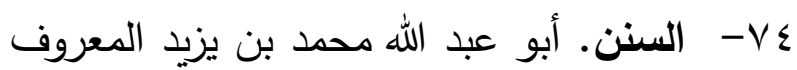

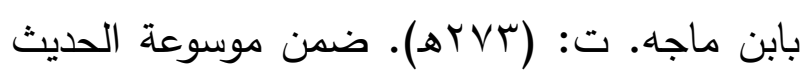

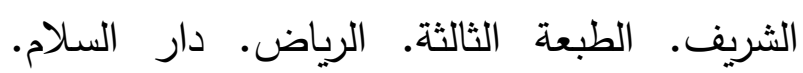
.ه ( $\{r \mid$

-Vo السنن. أبو داود سليمان بن الأشعث بن

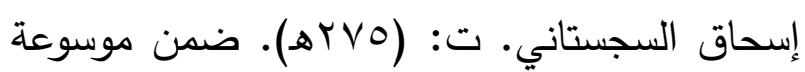
الحديث الشريف. الطبعة الثالثة. الرياض. لـاض دار السلام. اله \& أه. أ -VT - سير أعلام النبلاء. شمس الدين محمد بن

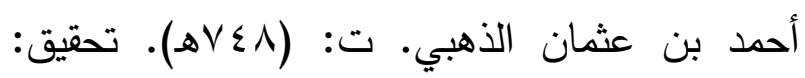

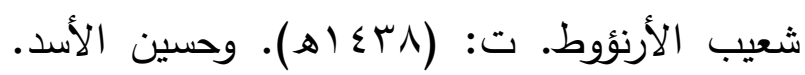
ومحمد نعيم العرقسوسي. ومأمون صاغرجي. وعلي الأروطي أبوزيد. ونذير حدان. وكامل الخراط. وصنالح 
بلبان. ت: (هو (ه) . تحقيق: شعيب الأرناؤوط. ت:

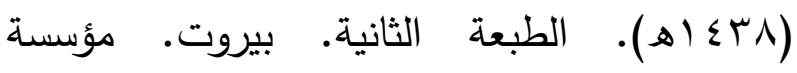

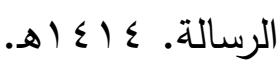

199- الصحيح من أحاديث السيرة. محمد بن حمد الصوياني. الطبعة الأولى. الرياض. مدار الوطن

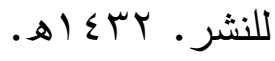
• - صحيح سنن أبي داود. محمد ناصر الدين الألباني. ت. ( • ؟ أهـ). الطبعة الأولى. الرياض. مكتبة المعارف. 1- الصلة في تاريخ أئمة الأندلس. أبو القاسم خلف بن عبد الملك ابن بشكوال. ت: (oVA هـ). تصحيح: السيد عزت العطار الحسيني. الطبعة الثانية. مكتبة الخانجي. ع \س أه. rو- الصواعق المرسلة على الجهمية والمعطلة. أبو عبد الله شمس الدين محمد بن أبي بكر المعروف بابن قيم الجوزية. ت: (101) (10). تحقيق: علي محمد الدخيل الله. الطبعة الثالثة. الرياض. دار

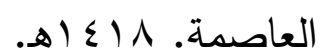
بو- طبقات الحنابلة. أبو الحسين محمد بن أبي يعلى الفراء البغدادي. ت: (דبهـ). تحقيق: عبد الرحمن بن سليمان العثيمين. ت: (بساء اهـ). الرياض. الأمانة العامة لمرور مائة عام على تأسيس

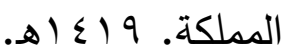
ع 9- الطبقات الكبرى. محمد بن سعد بن منيع. ت: (·rMه). تحقيق: محمد عبد القادر عطا. r r- شرح صحيح البخاري. أبو الحسن علي بن خلف بن عبد الملك المعروف بابن بطال. ت: (§१ §ه). تحقيق: أبو تميم ياسر بن إبراهيم. الطبعة الثانية. الرياض. مكتبة الرشد. سبع اهـ. rی- شرح صحيح مسلم. أبو زكريا يحيى بن

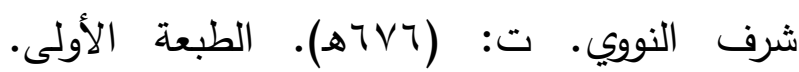

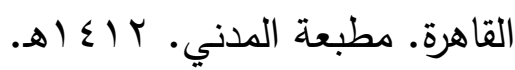
ع- الثريعة. أبو بكر محمد بن الحسين الآجري. ت: ( • بسه). تحقيق: عبد الله بن عمر الدميجي. الطبعة الثانية. الرياض. دار الوطن. . • ؟ أهـ. 01- شعب الإيمان. أحمد بن الحسين البيهقي. ت: ( الأولى. بيروت. دار الكتب العلمية. ـــ اهـ. Tی - شفاء العليل في مسائل القضاء والقدر والحكمة والتعليل. أبو عبد الله شمس الدين محمد بن أبي بكر المعروف بابن القيم. ت: (101 (هـ). تحقيق: محمد بدر الدين النعساني. بيروت. دار

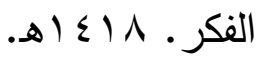
- - الصارم المسلول على شاتم الرسول. تقي الدين أبو العباس أحمد بن عبد الحليم بن عبد السلام ابن تيمية الحراني الحنبلي الدمشقي ت:

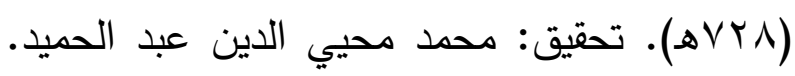
المملكة العربية السعودية. الحرس الوطني السعودي. . $1 \leqslant \cdot r$ - - صحيح ابن حبان. أبو حاتم محمد بن حبان البستي. ت: (عهاهـ. ترتيب: علاء الدين ابن 
1. 1- عون المعبود على شرح سنن أبي داود.

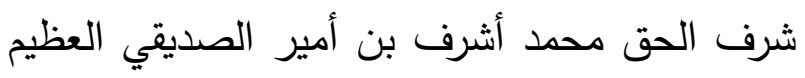

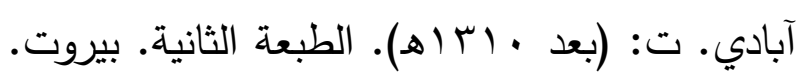

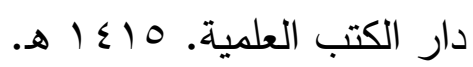

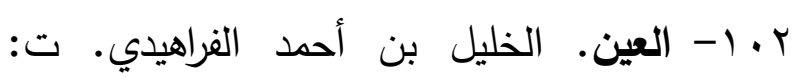

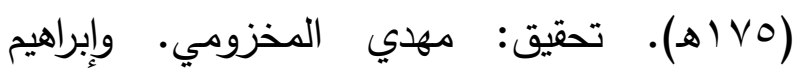
السامرائي. دارالهلال.

r. ا- عيون الأنباء في طبقات الأطباء. أحمد بن

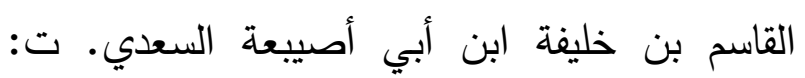

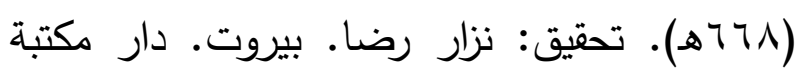
الحياة. ـ ـ ا - غريب القرآن. عبد الله بن مسلم ابن قتيبة.

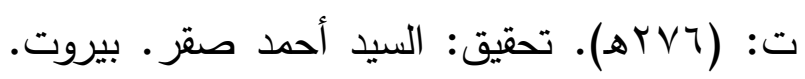
دار الكتب العلمية. 91 ب أهـ. ه. 1 - فتح القدير. ـ محمد بن علي الشوكاني. ت:

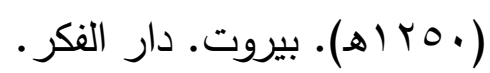

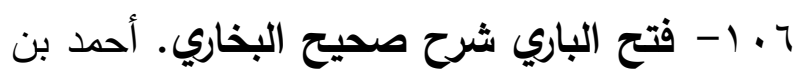

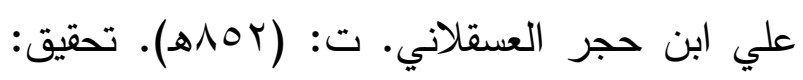

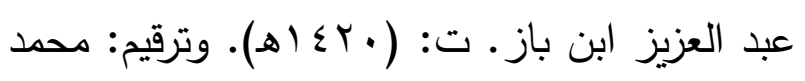

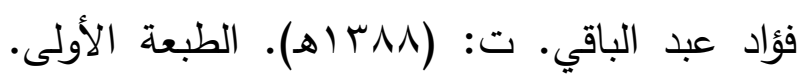

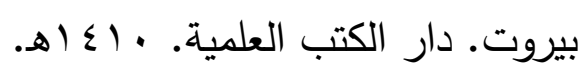
V. 1. - فقه الإيمان على منهج السلف الصالح. وميض رمزي صديق العمري. الطبعة الأولى. لإنهان.

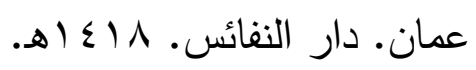
1. 1- الفقيه والمتفقه. أحمد بن علي الهن المعروف

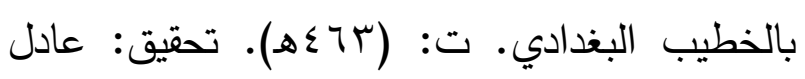

الطبعة الأولى. بيروت. دار الكتب العلمية. .ه أ 9-9 - الطبقات الكبرى الطبقة الرابعة من الصحابة.

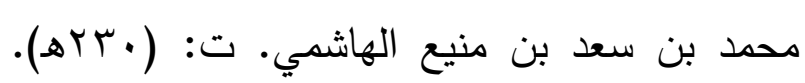
تحقيق: عبد العزيز عبد الله السلومي. الطائف. مكتبة الصديق. 71 إك أهـ

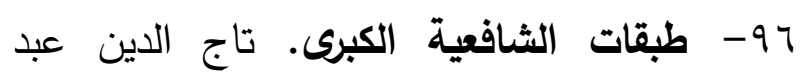

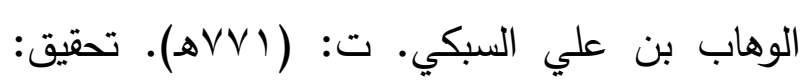
عبد الفتاح الحلو. ومحمود الطناحي. الطبعة الثانية.

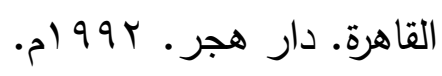
-9V عمرو عثمان بن عبد الرحمن المعروف بابن الصلاح ت: (بآجه). تحقيق: محيي الدين علي

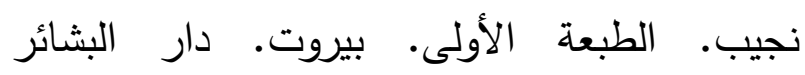

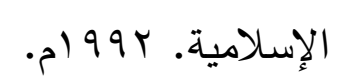

19 - العقيدة الطحاوية. أبو جعفر أحمد بن محمد

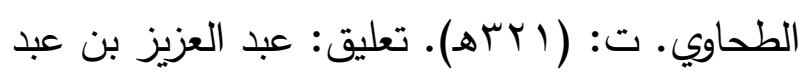

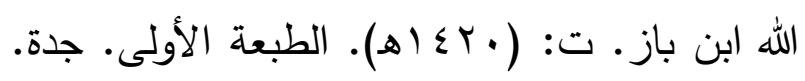

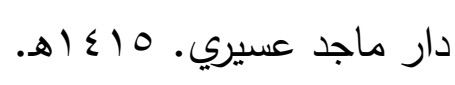
99 - عقيدة أهل السنة والجماعة (مفهومها - مائل خصائصها - خصائص أهلها). محمد إبراهيم الحمد. الطبعة الثانية. الرياض. دار ابن خزيمة. .8) $\leqslant 19$ . . . . العقيدة في الله. عمر بن سليمان الأشقر.

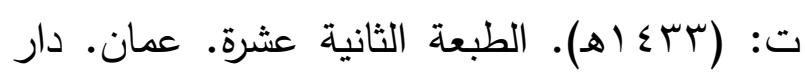
النفائس. 9 (إ) (هـ. 
110 - مجموع الفتاوى. أحمد بن عبد الحليم ابن

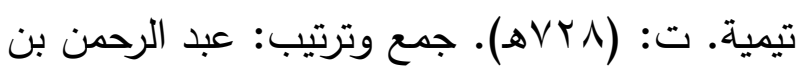
محمد بن قاسم. ت: (Y (T/اهـ) وابنه محمد. ت:

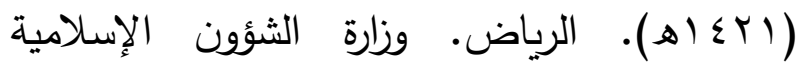

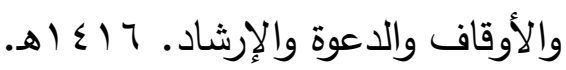
ד11 - المحر الوجيز في تفسير كتاب العزيز. أبو محمد عبد الحق بن غالب بن عطية الأندلسي. ت:

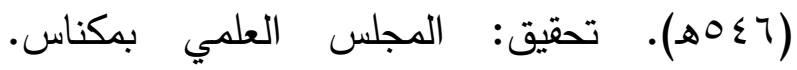
با

VIIV - مختار الصحاح. محمد بن أبي بكر بن عبد القادر الرازي. ت: (بعد דا7هـ). بيروت. مكتبة

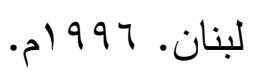

111 - مدارج السالكين بين منازل إياك نعبد وإياك نستعين. أبو عبد الله شمس الدين محمد بن أبي بكر المعروف بابن قيم الجوزية. ت: ( (101هـ). تحقيق: محمد حامد الفقي. ت: (TVA (أه). الطبعة الثانية. بيروت. دار الكتاب العربي. سو باهـ. 9 119- مدخل لاراسة العقيدة الإسلامية. عثمان

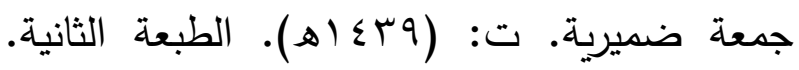

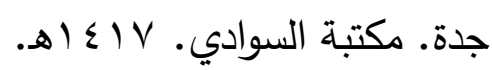
• r ا مرويات غزوة الخندق. إبراهيم بن محمد المدخلي. الطبعة: الأولى. المدينة المنورة. عمادة البحث العلمي بالجامعة الإسلامية. ع ₹ ـ اهـ.

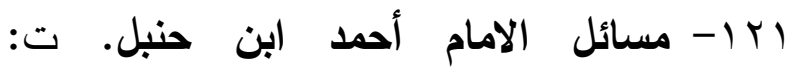

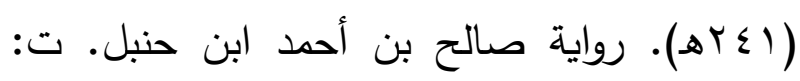

يوسف. الطبعة الثانية. الرياض. دار ابن الجوزي. . 9 . 1- القاموس المحيط. مجد الدين محمد بن يعقوب الفيروز آبادي. ت: ( السادسة. بيروت. مؤسسة الرسالة. 9 (؛ أهـ. • 11- الكثف عن مناهج الأدلة. محمد بن أحمد ابن رشد (الحفيد). ت: (1090هـ). الطبعة الأولى. بيروت. مركز دراسات الوحدة العربية. 9 أم. أ. 111 - كثف الخفا ومزيل الإلباس عما اشتهر من الأحاديث على ألسنة الناس. إسماعيل بن محمد العجلوني. ت: (r7 ا (هـ). تحقيق: أحمد القلاش. الطبعة الرابعة. بيروت. مؤسسة الرسالة. 0 . ع أهـ. ץ 11 - الكليات. أبو البقاء أيوب بن موسى الحسيني الكفوي. ت: (؟9. (اه). تحقيق: عدنان درويش ومحمد المصري. الطبعة الثانية. دمشق. وزارة الإعلام والثقافة والإرشاد القومي. سا1 - لسان العرب. جمال الدين محمد بن مكرم

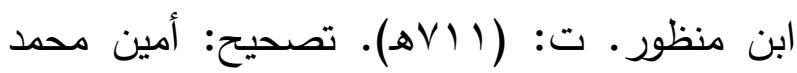
عبد الوهاب. ومحمد الصادق العبيدي. الطبعة الأولى. بيروت. دار إحياء التراث العربي. ومؤسسة

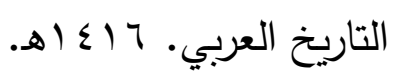
ع 1 - مجمع الزوائد ومنبع الفوائد. أبو الحسن نور الدين علي بن أبي بكر بن سليمان الهيثي ت:

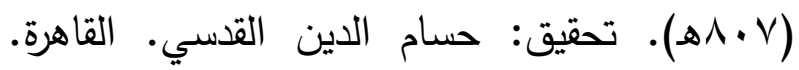
مكتبة القدسي. ع إ أهـ 
اله I I V المصنف في الأحاديث والآثار. أبو بكر عبد

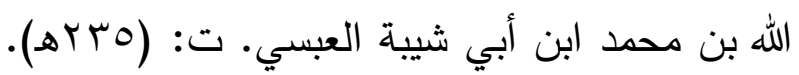
تحقيق: كمال يوسف الحوت. الطبعة الأولى. الرياض. مكتبة الرشد. 9 • ـ أهـ.

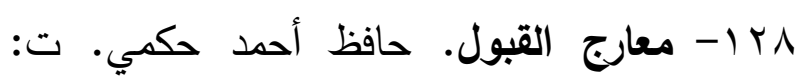

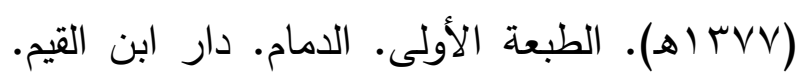
. أ

9 ا ו - معالم التنزيل. أبو محمد الحسين بن مسعود

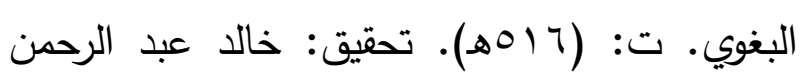

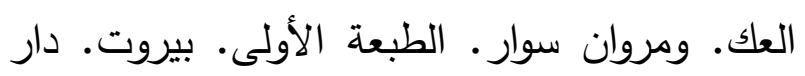
المعرفة. 7 • ـ أهـ • با - معالم السنن شرح سنن أبي داود. أبو

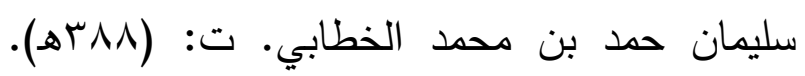

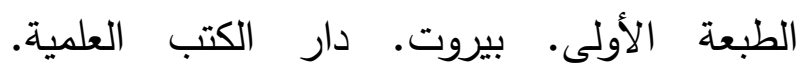
. (1) 19

ابا - معاني القرآن. أبو زكريا يحيى بن زياد

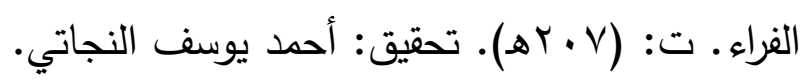

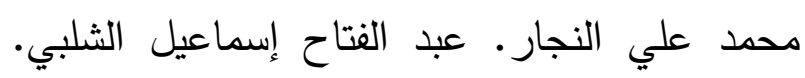
الطبعة الأولى. مصر . الدار المصرية.

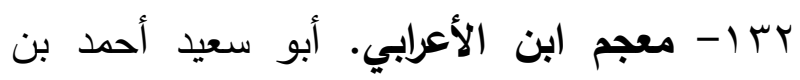

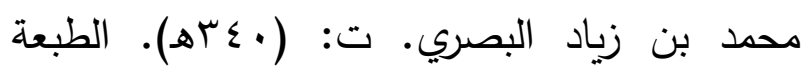

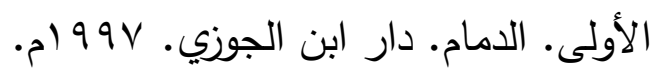

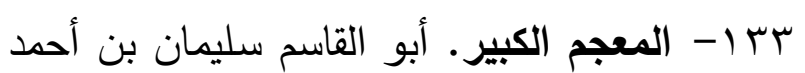

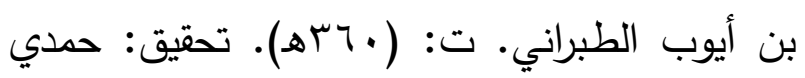
عبد المجيد السلفي. الطبعة الثانية. المدينة النبوية. مكتبة العلوم والحكم. ؟ . ـ الهـ.

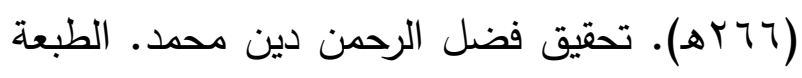

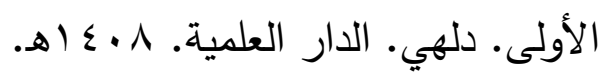

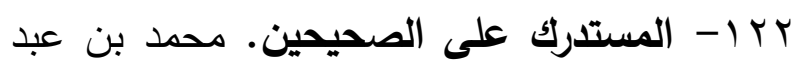

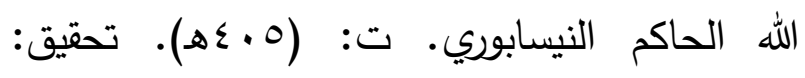
مصطفى عبد القادر عطا. الطبعة الأولى. بيروت. دار الكتب العلمية. الاء اهـ. بr ا - المسند الصحيح المختصر من السنن بنقل العدل عن العدل عن رسول الله أبو الحسين مسلم بن الحجاج القشيري. ت ت: (آYTه). ضمن موسوعة الحديث الشريف. الطبعة

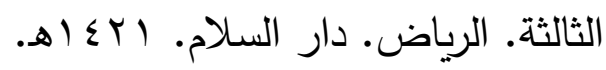
ع Y ا- المسند. أبو عبد الله أحمد بن محمد بن الرئ

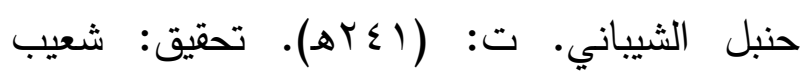

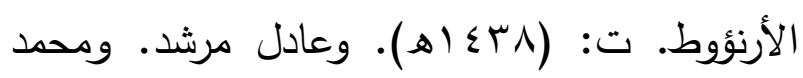
نعيم العرقسوسي. وإبراهيم الزببق. وعامر غضبنان. وعان.

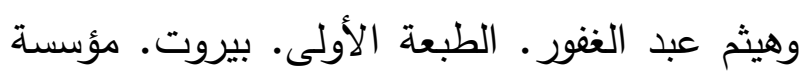

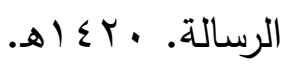

هץ ا - المصباح المنير في غريب الثرح الكبير. أحمد بن محمد بن علي الفيومي. ت: ( • (لطحه). الطبعة الأولى. بيروت. دار الكتب لعدئ العلمية. .ه بr| - المصنف. عبد الرزاق بن همام الصنعاني. ت: (IIII) (Y) تحقيق: حبيب الرحمن الأعظمي.

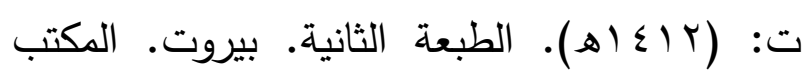
الإسلامي. r +. أهـ. 
1 إ- مناقب الثافعي. أبو بكر أحمد بن الحسين

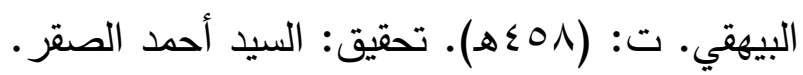
الطبعة الأولى. القاهرة. دار التراث. . وس اهـ. r إ- منهاج السنة النبوية. أحمد بن عبد الحليم

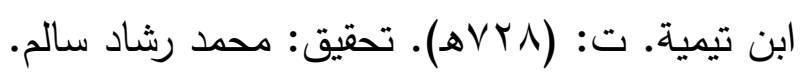

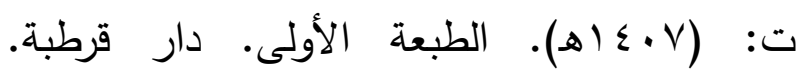
7 بـ ا- المنهاج السوي في ترجمة الإمام النووي. جلال الدين أبو الفضل عبد الرحمن السيوطي. ت: (119ه). تحقيق: أحمد شفيق دمج. الطبعة الأولى.

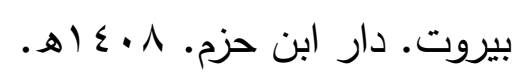
§ أ- منهج الاستدلال على مسائل الاعتقاد عند أهل السنة والجماعة. عثمان علي حسن. الطبعة

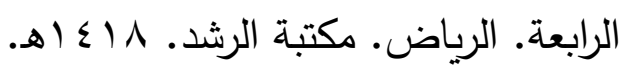
0 1 - منهج السلف والمتكلمين في موافقة العقل للنقل وأثر المنهجين في العقيدة. جابر إدري علي أمير. الطبعة الأولى. الرياض. مكتبة أضواء

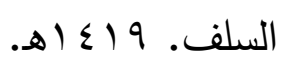
ح ا ا - الموافقات في أصول الثربعة. إبراهيم بن موسى الشاطبي. ت: (·. (ه). شرح: محمد عبد

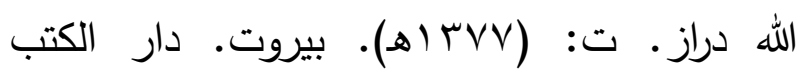

العلمية.

\&V محمد بن عبد الكريم الثهرستاني. ت: (^乞 مهـ). تحرير وتصحيح: الفرد جيوم. القاهرة. مكتبة
ع آ- المعجم الوسيط. إبراهيم مصطفى وأحمد الزيات وحامد عبد القادر ومحمد النجار. القاهرة. مجمع اللغة العربية. دار الدعوة. هץ ا - معرفة الصحابة. أبو نعيم أحمد بن عبد الله الأصبهاني ت: (·ـــ). تحقيق: عادل العزازي. الطبعة الأولى. الرياض. دار الوطن. 9 أـ أه. דبا- المعرفة في الإسلام مصادرها ومجالاتها. عبد الله بن محمد القرني. الطبعة الأولى. مكة الألى المكرمة. دار عالم الفوائد. 9 1؛ اهـ. VT ا - مفتاح دار السعادة ومنشور ولاية العلم والإرادة. أبو عبد الله شمس الدين محمد بن أبي بكر المعروف بابن قيم الجوزية. ت: (101هـ). بيروت. دار الكتب العلمية.

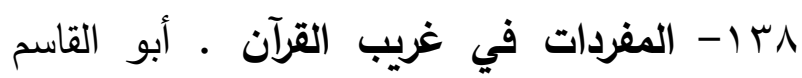

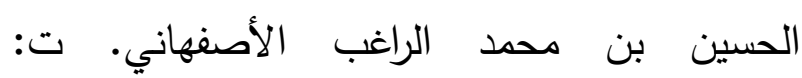

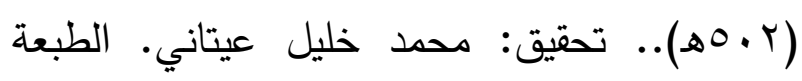

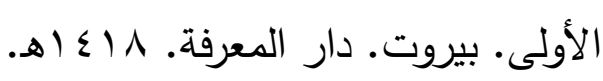
وب ا- مقاييس اللغة. أبو الحسين أحمد بن فارس لارس بن زكريا الرازي. ت: (90هـ). تحقيق: عبد السلام محمد هارون. ت: (1 · ع اهـ ). بيروت. دار الجيل. . $1 \leqslant Y$. • ـ ا- المقصد الأرشد في ذكر أصحاب الإمام أحمد. برهان الدين إبراهيم بن محمد ابن مفلح

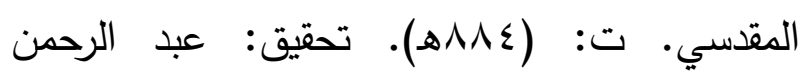
العثيمين. ت: (דبـ اهـ). الطبعة الأولى. الرياض. مكتبة الرشد. • (1) أهـ. 
أسماء بنت داود بن أحمد العلواني

$\varepsilon \varepsilon$

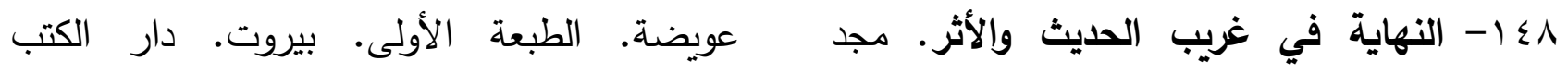

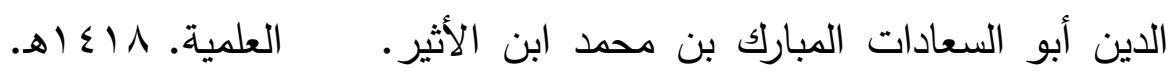

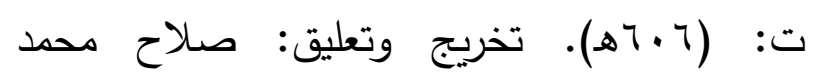




\title{
The Effects of Surrendering to The Islamic Texet, in The Integrity of Belief
}

\author{
Asma Dawood Ahmad AlAlwani \\ Facult of the holy Quran and Islamic Studies \\ University of Jeddah
}

\begin{abstract}
Praise be to Allah, and may blessings and peace be upon his Messenger The book of Allah and the Sunnah of his prophet are the two main source of the Islamic creed. That is why the submission to them is very important in Islam and had been confirmed by their texts and called for in more than one place, hence the importance of the subject of the research, as well as the following reasons:

Greatest importance of the integrity of the faith to survive in this world and the hereafter.

That many matters of islamic creed are unseen, and there must be a solid evidence for faith in them.

The guidance and the way to it is an objective for every believer to win the approval of Allah and to enter his paradise, and that the majority of delusion of those who have gone astray in matters of belief is due to the non-surrender of the Islamic texts.

What happens from time to time in some Islamic societies, outright calls aim to rebel against the Islamic texts.

This research includes in an introduction in it a statement of terms for the title of the topic. Then the first chapter: Which Include the referee to the submission for the Islamic texts, and texts evidence for that. Then the second chapter: Which include the results of surrender to the legal texts in the integrity of belief, and in it talk about what results from surrender of moderation of human belief and rightness, and the validity of his faith, and his mediation in the section of belief between the dear and the dural, his safety and his escape from delusion and transgressing the limits of Allah.
\end{abstract}

Key words: Surrendering, Islamic Texet, Integrity ,Belief. 